\title{
STRATIGRAPHIC AND RESERVOIR QUALITY STUDIES OF CONTINUOUS CORE FROM THE WAINWRIGHT \#1 COALBED METHANE TEST WELL, WAINWRIGHT, ALASKA
}

David L. LePain

Editor

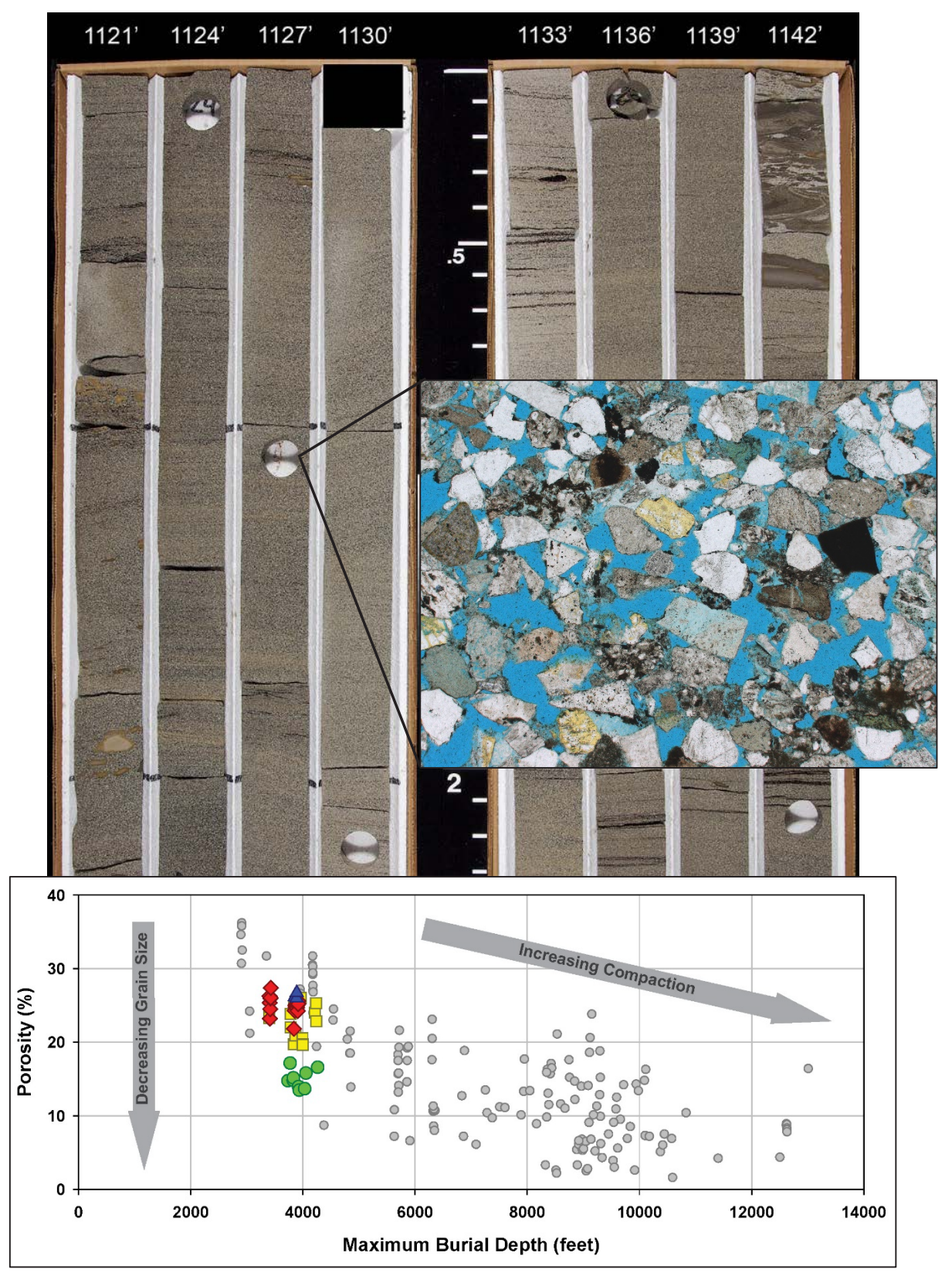

Published by

STATE OF ALASKA

DEPARTMENT OF NATURAL RESOURCES

DIVISION OF GEOLOGICAL \& GEOPHYSICAL SURVEYS 
Section three of this report was updated August, 2019. 


\section{STRATIGRAPHIC AND RESERVOIR QUALITY STUDIES OF CONTINUOUS CORE FROM THE WAINWRIGHT \#1 COALBED METHANE TEST WELL, WAINWRIGHT, ALASKA}

David L. LePain, editor

Report of Investigations 2016-3

State of Alaska

Department of Natural Resources

Division of Geological \& Geophysical Surveys 



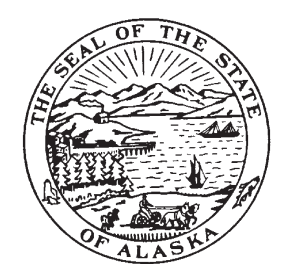

\section{STATE OF ALASKA}

Bill Walker, Governor

DEPARTMENT OF NATURAL RESOURCES

Andy Mack, Commissioner

\section{DIVISION OF GEOLOGICAL \& GEOPHYSICAL SURVEYS}

Steve Masterman, State Geologist and Director

Publications produced by the Division of Geological \& Geophysical Surveys (DGGS) are available for download from the DGGS website (www.dggs.alaska.gov). Publications on hardcopy or digital media can be examined or purchased in the Fairbanks office:

\section{Alaska Division of Geological \& Geophysical Surveys \\ 3354 College Rd., Fairbanks, Alaska 99709-3707 \\ Phone: (907) 451-5010 Fax (907) 451-5050 \\ dggspubs@alaska.gov \\ www.dggs.alaska.gov}

Alaska State Library

State Office Building, 8th Floor

333 Willoughby Avenue

Juneau, Alaska 99811-0571
Alaska Resource Library \& Information Services (ARLIS)

3150 C Street, Suite 100

Anchorage, Alaska 99503-3982 


\section{INTRODUCTION}

This three-chapter volume summarizes the Alaska Department of Natural Resources' study of a continuously cored succession of coal-bearing strata in the Albian-Cenomanian Nanushuk Formation from the Wainwright \#1 core hole, located in the community of Wainwright in northwestern Alaska. The U.S. Geological Survey drilled Wainwright \#1 in 2007 to conduct a preliminary evaluation of the coalbed methane potential of the Nanushuk Formation. The Alaska Divisions of Geological \& Geophysical Surveys and Oil and Gas described the core and conducted a detailed facies analysis. In addition, all major sandy facies in the core were plugged for porosity and permeability measurements and thin-section analysis.

The cored succession includes approximately 1,530 feet of mudstone-dominated delta plain strata. A significant number of sandstone beds are scattered throughout the core, along with several thick sandstone packages. Mud-rich successions such as this typically do not make for good, long, continuous exposures, and this is certainly the case in the Nanushuk outcrop belt to the south of Wainwright. For this reason, the Wainwright core provides an uninterrupted and unparalleled view of the transition from marine-influenced lower delta plain facies to fully nonmarine upper delta plain facies, and the opportunity to examine the reservoir quality of a variety of sand bodies deposited in these settings.

Chapter 1, by Decker and LePain, places the Wainwright \#1 core hole in a regional stratigraphic context using a publicly available 2D seismic line that ties the Tunalik 1 (projected), Wainwright \#1, Peard 1, and Kugrua 1 (projected) wells, and a wireline log-based cross-section using these same wells. Chapter 2, by LePain and Decker, includes a detailed core description and facies analysis of the cored interval. Chapter 3 , by Helmold, summarizes the petrology and reservoir quality of siltstones and sandstones in the cored succession. These results are timely given renewed exploration interest in the Nanushuk Formation spurred by Repsol's and Armstrong's recent discovery of a major reservoir in deltaic sandstones in the Nanushuk east of Wainwright, in the Colville delta area.

Front Cover Photo: Core photograph showing faintly laminated, medium-grained sandstone from a thick distributary channelfill succession in the Wainwright \#1 core hole. The inset photomicrograph shows a lithic arenite with nearly 27 percent porosity at a measured depth of 1,128.1 feet. This thin-section was cut from the butt-end of the plug removed from the core at this depth (circular hole in core). The blue areas in the photomicrograph represent pore space. The porosity versus depth plot shows that grain size is the main control on porosity in sandstones from the Wainwright core. LePain and Decker (this volume) discuss facies identified in the Wainwright core and Helmold (this volume) discusses the petrology of sandstones in the core and implications for reservoir quality. 


\section{CONTENTS}

1 Subsurface relationships of Albian-Cenomanian shallow marine to nonmarine topsets of the Nanushuk Formation, northwestern NPRA, northern Alaska

Paul L. Decker and David L. LePain

Sheet 1-1 Subsurface relationships of Albian-Cenomanian shallow marine to nonmarine topsets of the Nanushuk Formation, northwest NPRA.

doi:10.14509/29655

5 Lithofacies analysis of the Wainwright \#1 continuous core, western Arctic Slope, Alaska: Transition from lower to upper delta plain environments in the Albian-Cenomanian Nanushuk Formation

David L. LePain and Paul Decker

Sheet 2-1 Continuously cored topsets of the Albian-Cenomanian(?) Nanushuk Formation, Wainwright No. 1 well, northwestern Alaska: Deposition in a marine-influenced delta plain setting

doi:10.14509/29656

37 Sedimentary petrology and reservoir quality of Albian-Cenomanian Nanushuk Formation sandstones, USGS Wainwright \#1 test well, western North Slope, Alaska

Kenneth P. Helmold

Appendix 3-A. List of Point-Counted Samples

Appendix 3-B. Routine Core Analyses

Appendix 3-C. Raw Petrographic Data in Wilson Format

Appendix 3-D. Raw Petrographic Data in Decker-Helmold Format

Appendix 3-E. Summary of Petrographic Data

Appendix 3-F. Petrographic Ratios Used to Construct Ternary Diagrams

Appendix 3-G. Grain Size Data in $\varphi$ (phi) Units

Original point count data from Dr. Michael Wilson

doi:10.14509/29657 



\title{
SUBSURFACE RELATIONSHIPS OF ALBIAN-CENOMANIAN SHALLOW MARINE TO NONMARINE TOPSETS OF THE NANUSHUK FORMATION, NORTHWESTERN NPRA, NORTHERN ALASKA
}

\author{
Paul L. Decker ${ }^{1}$ and David L. LePain ${ }^{2}$
}

\begin{abstract}
This brief text and accompanying poster (sheet 1-1) provide regional stratigraphic and structural context for the Wainwright 1 and 1A wells drilled in 2007 by the U.S. Geological Survey (USGS) to investigate coalbed methane potential in the northwestern National Petroleum Reserve-Alaska (NPRA). The Wainwright 1 well was cored continuously from 75 to 1,605 ft (22.9-489.2 m) total depth, and a suite of high-resolution, slim-hole well logs has been compiled from both holes, providing a unique dataset for interpreting the sedimentology, stratigraphic architecture, and reservoir quality of Brookian topset strata of the middle and upper Nanushuk Formation.

The Wainwright 1/1A core and log data document the upward transition from predominantly marine to fully nonmarine depositional settings accompanying east-northeastward progradation of topset strata during Albian to Cenomanian time. Tentative correlations with wells up to tens of kilometers away are possible with the benefit of seismic data. Intervals of fluvial sandstone up to $30 \mathrm{~m}$ thick (recognized in core and well logs) that appear to correlate across these long distances are interpreted as mobile channel-belt deposits; their continuity suggests they are associated with sequence boundaries (regressive surfaces of erosion) that are otherwise difficult to interpret in nonmarine settings. Many coal-bearing intervals also appear to correlate across these long distances, but it is considered unlikely that individual coal seams or sand bodies are continuous among the widely separated wells. The plausible widespread correlation of coaly intervals (likely late transgressive to early highstand systems tracts) and mobile channel belts (likely falling stage to lowstand systems tracts) suggests that expansive areas of the Nanushuk coastal plain were subject to changes in relative sea level, probably due to low relief.
\end{abstract}

\section{DISCUSSION}

This brief paper is part of a three-chapter study that also includes detailed core description and facies analysis (LePain and Decker 2016 [this volume]) and reservoir quality study (Helmold, 2016 [this volume]). This chapter's objective is to place the continuously cored Wainwright $1 / 1 \mathrm{~A}$ well into its regional context using seismic and well log correlations and to note details in core and logs from the well that reflect that greater framework.

The location map (fig. 1-1 of sheet 1-1) identifies the Wainwright $1 / 1 \mathrm{~A}$ location relative to other key exploration wells (Tunalik 1, Peard 1, and Kugrua 1) drilled in northwestern NPRA, as well as the regional two-dimensional (2-D) public seismic grid acquired by the USGS. Seismic transect $A-A^{\prime}$ is spliced together from several different lines to roughly approximate the path of well log correlation section B-B'. Transect A-A' is longer than section B-B', (197 versus $120 \mathrm{~km}$ ), providing context beyond the points of well control on both the west and east ends. The overall west-southwest to east-northeast orientation of both sections is dictated by the location of wells in the area, but is also a reasonable approximation of the general depositional dip and progradation direction in this part of the North Slope during Albian to Cenomanian time (Molenaar, 1985; Huffman and others, 1985).
Several Nanushuk Formation conventional gas reservoirs were discovered in the late 1940s through the mid-1960s in anticlinal traps in the northern foothills compressional province (Schindler, 1988). None of those discoveries lie on the seismic transect or well log section; the Nanushuk gas accumulation discovered by the Meade 1 well is shown to the southeast in figure 1-1 (sheet 1-1).

Figure 1-2 (sheet 1-1) shows two versions of the interpreted seismic transect; the upper version is displayed using a sea level datum, and the lower version is flattened on a shallow horizon in the Nanushuk Formation topsets in this area. Several major bends in the transect significantly exaggerate the structural expression of the Meade Arch. The arch is clearly expressed in the thickness variations of the Ellesmerian and Beaufortian units, but at the Nanushuk level in the area of these wells, structure has a nearly homoclinal southerly dip.

A key aspect of the seismic interpretation is the markedly time-transgressive nature of the toplap surface between the foreset seismic facies (Torok Formation) and the topset seismic facies (predominantly Nanushuk Formation); the purple horizon clearly steps across seismic reflections. The topset seismic facies can be further subdivided into a lower, relatively transparent interval characterized by minor internal acoustic contrast, and an upper, relatively reflective interval with greater

\footnotetext{
${ }^{1}$ Alaska Division of Oil and Gas, 550 West 7th Avenue, Suite 800, Anchorage, AK 99501-3560; paul.decker@alaska.gov

${ }^{2}$ Alaska Division of Geological \& Geophysical Surveys, 3354 College Road, Fairbanks, AK 99709-3707; david.lepain@alaska.gov
} 
impedance contrast. Integrated with log and lithologic data from the wells, these intervals are interpreted to correspond to the dominantly marine lower Nanushuk and dominantly nonmarine, coal-bearing upper Nanushuk strata. The orange seismic horizon represents the gradational contact between the marine- and nonmarinedominated topsets. Correlations with the wells suggest this transition is also time transgressive, although to a lesser degree than the toplap surface at the base of the topsets, with the most pronounced up-section step located between the Peard 1 and Kugrua 1 wells.

The well correlation section of figure 1-3 (sheet 1-1) is flattened on a shallow datum picked in seismic data and tied to well control using integrated sonic log time-depth relationships. The center track of the composite log display is color coded to depict log-derived interpretations of lithology. Given the tens of kilometers between wells and the nonmarine to shallow marine setting, all correlations are tentative and inferred to represent approximately time-equivalent horizons, not necessarily continuous lithosomes. Even so, it appears reasonable to correlate two intervals containing the thickest channel-fill sandstones in Wainwright 1/1A (1,060-1,158 ft [323.1-353 m] measured depth [MD] and 619-667 ft [188.7-203.3 m] MD) to well-developed though slightly thinner intervals in similar stratigraphic position in the other wells. Continuity of sandstone-dominated, channelized fluvial intervals between the wells at these distances suggests they may represent broad channel belts, within which generally east-flowing stream channels migrated laterally over time, depositing sheet-like sands throughout a broad swath of the coastal plain. In addition, it is reasonable to correlate the coaly intervals penetrated at approximate depths of $100 \mathrm{ft}(30.5 \mathrm{~m}), 240 \mathrm{ft}(73.2 \mathrm{~m})$, and $305 \mathrm{ft}(93 \mathrm{~m}) \mathrm{MD}$ in Wainwright $1 / 1 \mathrm{~A}$ across long distances between wells, in the case of the lower two coals, spanning a distance of approximately $100 \mathrm{~km}$.

The widespread distribution of apparently correlative fluvial sandstones up to $30 \mathrm{~m}$ (100 ft) thick interpreted as mobile channel-belt deposits suggests they are associated with falling stage to lowstand systems tract sequence boundaries rather than local accommodation afforded by autocyclic processes. Similarly, coaly intervals present in the upper part of the Wainwright 1/1A wells appear to correlate among the widely separated wells and probably represent late transgressive to early highstand systems tracts. The lateral continuity of these systems tracts at distances approaching $100 \mathrm{~km}$ implies that expansive areas of the Nanushuk coastal plain responded approximately simultaneously to changes in relative sea level, consistent with low topographic relief.

The section penetrated by the Wainwright 1 and $1 \mathrm{~A}$ holes falls within the middle to upper portion of the Albian-Cenomanian Nanushuk Formation topsets. Below about $1,320 \mathrm{ft}(402.3 \mathrm{~m}) \mathrm{MD}$, the section appears dominated by marine facies (LePain and Decker, 2016 [this volume]), with minimal coal, and widespread occurrences of a relatively diverse suite of trace fossils (relatively common Thalassinoides as well as occasional Skolithos, Diplocraterion, Asterosoma, Rhizocorallium, Paleophycos, Teichichnus, Planolites, Phycosiphon, and Anchonichnus or Helminthopsis). Above 1,320 ft (402.3 m) MD, nonmarine characteristics predominate, including more abundant and thicker coals and zones of paleosol development (LePain and Decker, 2016 [this volume]), but there are still a number of relatively thin intervals bearing a slightly less diverse trace fossil suite (sporadic occurrences of Thalassinoides, Skolithos, Diplocraterion, Rossellia, Rhizocorallium, and Paleophycos). Above about $265 \mathrm{ft}(80.8 \mathrm{~m}) \mathrm{MD}$, there are no indications of marine influence, with strata interpreted to represent deposition entirely in alluvial to upper delta plain environments (LePain and Decker, 2016 [this volume]). Thus, the Wainwright $1 / 1 \mathrm{~A}$ well is interpreted to illustrate the general upward transition toward more proximal facies, consistent with the overall progradational nature of the Nanushuk Formation.

\section{SUMMARY}

Two themes emerge from placing the continuously cored Wainwright $1 / 1 \mathrm{~A}$ in its regional context. First, coalbearing horizons and fluvial channel-belt deposits exhibit a high degree of lateral continuity, at least in the proximalto-distal direction, in the middle and upper Nanushuk Formation of the western North Slope. This is consistent with depositional responses linked to changes in relative sea level across expansive systems tracts. Second, the core and context provide new insights into the frequency and extent of marine and brackish influence on dominantly nonmarine facies of the lower delta plain.

\section{ACKNOWLEDGMENTS}

The authors thank several colleagues whose assistance made this study possible. David Houseknecht and Arthur Clark of the USGS facilitated access to the core during its transit through Anchorage. Dede Schwarz, Dan Przywojski, and Mike McCracken of ConocoPhillips Alaska approved and arranged core layout at the Anchorage Bayview core facility. We thank Paul McCarthy and Marwan Wartes for technical reviews of the manuscript.

\section{REFERENCES CITED}

Helmold, K.P., 2016 [this volume], Sedimentary petrology and reservoir quality of Lower Cretaceous Nanushuk sandstones, USGS Wainwright \#1 test well, western North Slope, Alaska, in LePain, D.L., ed., Stratigraphic and reservoir quality studies of continuous core from the Wainwright \#1 coalbed methane test well, Wainwright, Alaska: Alaska Division of Geological \& Geophysical Surveys Report of Investigation 2016-3, 56 p. doi:doi:10.14509/29657

Huffman, A.C., Jr., Ahlbrandt, T.S., Pasternack, I., Stricker, G.D., and Fox, J.E., 1985, Depositional and 
sedimentologic factors affecting the reservoir potential of the Cretaceous Nanushuk Group, central North Slope, Alaska, in Huffman, A.C., Jr., ed., Geology of the Nanushuk Group and related rocks, North Slope, Alaska: U.S. Geological Survey Bulletin 1614, p. 61-74. LePain, D.L., and Decker, P.L., 2016 [this volume], Lithofacies analysis of the Wainwright \#1 continuous core, western Arctic Slope, Alaska-Transition from lower to upper delta plain environments in the Nanushuk Formation, in LePain, D.L., ed., Stratigraphic and reservoir quality studies of continuous core from the Wainwright \#1 coalbed methane test well, Wainwright, Alaska: Alaska Division of Geological \& Geophysical Surveys Report of Investigation 2016-3, 56 p. doi:10.14509/29656
Molenaar, C.M., 1985, Subsurface correlations and depositional history of the Nanushuk Group and related strata, North Slope, Alaska, in Huffman, A.C., Jr., ed., Geology of the Nanushuk Group and related rocks, North Slope, Alaska: U.S. Geological Survey Bulletin 1614, p. 37-60.

Schindler, J.F., 1988, History of exploration in the National Petroleum Reserve in Alaska, with emphasis on the period from 1975 to 1982, in Gryc, George, ed., Geology and exploration of the National Petroleum Reserve in Alaska, 1974 to 1982: U.S. Geological Survey Professional Paper 1399, p. 13-72. 



\title{
LITHOFACIES ANALYSIS OF THE WAINWRIGHT \#1 CONTINUOUS CORE, WESTERN ARCTIC SLOPE, ALASKA: TRANSITION FROM LOWER TO UPPER DELTA PLAIN ENVIRONMENTS IN THE ALBIAN-CENOMANIAN NANUSHUK FORMATION
}

\author{
David L. LePain ${ }^{1}$ and Paul Decker ${ }^{2}$
}

\section{INTRODUCTION}

During summer 2007 the U.S. Geological Survey (USGS) drilled a 1,605-ft-deep test hole in the village of Wainwright, along the Beaufort Sea coast southwest of Barrow, Alaska (fig. 2-1). Continuous core was cut in the Nanushuk Formation from a depth of 75 to $1,605 \mathrm{ft}$. The purpose of this hole was to sample and measure the gas content of coal seams. A second well was drilled nearby for testing purposes. Both wells were logged by the USGS with a high-resolution gamma-ray logging tool. This testing was part of an effort by the USGS (Clark, 2014) to evaluate the coalbed methane potential of nonmarine Nanushuk strata and determine their viability as a reliable energy source for Wainwright (fig. 2-2).

The Wainwright \#1 core provides an outstanding view of Albian-Cenomanian marginal-marine and nonmarine facies in the Nanushuk Formation (fig. 2-2) in an area characterized by widely scattered, low-lying outcrops. The core includes a thick succession of mud-dominated lower and upper delta plain facies that usually make poor outcrops. Where present in outcrop in the foothills belt north of the Brooks Range to the south and southeast, these facies are typically only exposed over short stratigraphic intervals. Thus the Wainwright \#1 core offers a unique opportunity to examine these facies over a stratigraphic thickness never continuously exposed in outcrop.

This report includes the resulting core log (sheet 2-1) and facies analysis. Decker and LePain (2016 [this volume]) place the Wainwright core in a regional stratigraphic context and Helmold (2016 [this volume]) discusses the reservoir quality of sandstones represented in the core.

For detailed discussions of the regional significance of the Nanushuk Formation, refer to Huffman and others $(1985,1988)$, Molenaar $(1985,1988)$, Mull (1985), Houseknecht and Schenk (2001, 2005), Decker (2007), Houseknecht and others (2008), LePain and Kirkham (2001), and LePain and others $(2008,2009)$.

\section{REGIONAL SETTING}

The Nanushuk Formation and coeval outer-shelf, slope, and basinal deposits of the upper Torok Formation fill the western two-thirds of a large Mesozoic-Cenozoic peripheral foreland basin (figs. 2-1 and 2-2). The basin is east-west trending and extends from approximately the
Alaska-Yukon border in the east to the Chukchi Sea coast in the west, and continues offshore to the Herald arch (Bird and Molenaar, 1992). The onshore part of the basin, referred to as the Colville basin, is bounded on its north side by the Barrow arch (fig. 2-1). The Barrow arch is a subsurface high that coincides approximately with the present-day north coast of Alaska, from Point Barrow to the Canning River, and represents a rift shoulder formed when Arctic Alaska separated from a northern landmass (present-day coordinates) in Neocomian time (Valanginian-Hauterivian) (Bird and Molenaar, 1992). The basin is bounded on its south side by the Brooks Range (fig. 2-1), an east-west-trending, north-vergent (present-day coordinates) fold and thrust belt (Moore and others, 1994). The fold and thrust belt consists of a thick stack of far-traveled allochthons emplaced northward during Neocomian time (Mull, 1985; Mayfield and others, 1988), in part contemporaneous with rifting to the north (Bird and Molenaar, 1992; Moore and others, 1994). The foreland basin formed in response to the load imposed by these allochthons (Mull, 1985; Mayfield and others, 1988), and was subsequently filled by detritus shed from them and from more distant sources on the Chukchi platform (and Russian Far East?).

The Nanushuk Formation is a succession of complexly intertonguing marine and nonmarine strata interpreted as marine shelf, deltaic, strandplain, fluvial, and alluvial overbank deposits (fig. 2-2; Huffman and others, 1985; LePain and others, 2009). Thickness estimates for the unit range from 9,020 feet in coastal exposures along the Chukchi Sea in the west (Ahlbrandt and others, 1979) to a zero edge $\sim 46 \mathrm{mi}(75 \mathrm{~km}$ ) east of Umiat (fig. 2-1). Ahlbrandt and others (1979) and Huffman and others (1985) recognized three large deltas" in the Nanushuk. These deltas were probably fed by multiple rivers, with each river building a stack of delta lobes through time and, as such, are more appropriately referred to as deltaic complexes (LePain and others, 2009). The Corwin complex dominates the Nanushuk west of the Meade arch and was interpreted by Ahlbrandt and others (1979) and Huffman and others (1985) to have been constructed by river-dominated deltas. The Corwin complex received sediment from a large drainage basin that extended west of present-day Arctic Alaska (Molenaar, 1985). The western deltas prograded toward the east-northeast, and gradually filled the western twothirds of the Colville basin (Houseknecht and Schenk, 2001; Houseknecht and others, 2008). East of the Meade arch Ahl-

\footnotetext{
${ }^{1}$ Alaska Division of Geological \& Geophysical Surveys, 3354 College Road, Fairbanks, AK 99709-3707; david.lepain@alaska.gov ${ }^{2}$ Alaska Division of Oil and Gas, 550 West 7th Avenue, Suite 800, Anchorage, AK 99501-3560; paul.decker@alaska.gov
} 

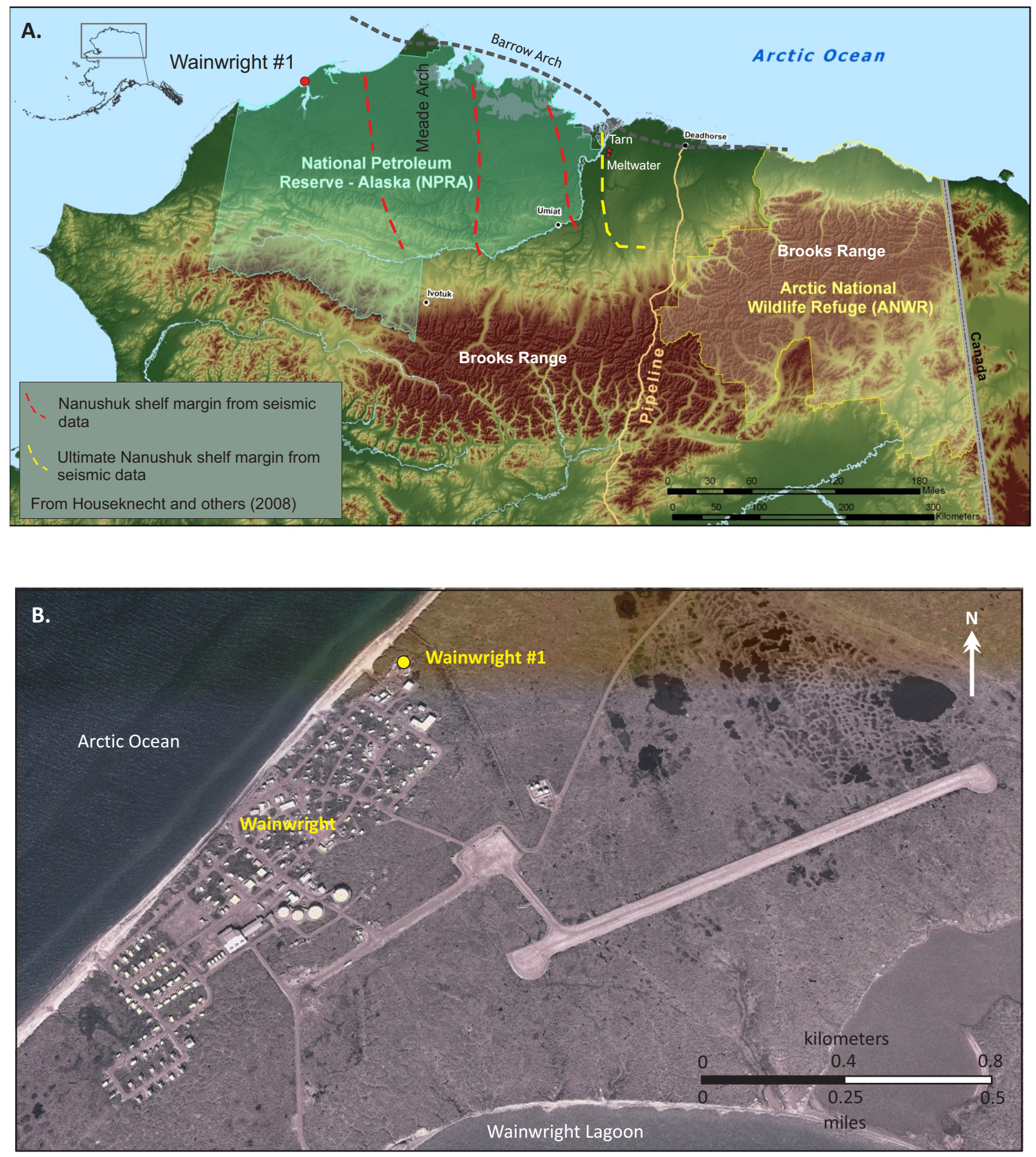

Figure 2-1. A. Shaded-relief map of northern Alaska, showing the location of the Wainwright \#1 well. The red dashed lines show Nanushuk shelf edge positions in the Colville basin through time (younger toward the east); the yellow dashed line shows the ultimate Nanushuk shelf edge. Shelf edge positions shown here are schematic and taken from Houseknecht and others (2008). B. Aerial photograph showing the Village of Wainwright and the location of the Wainwright \#1 well. Modified from Clark (2014). 


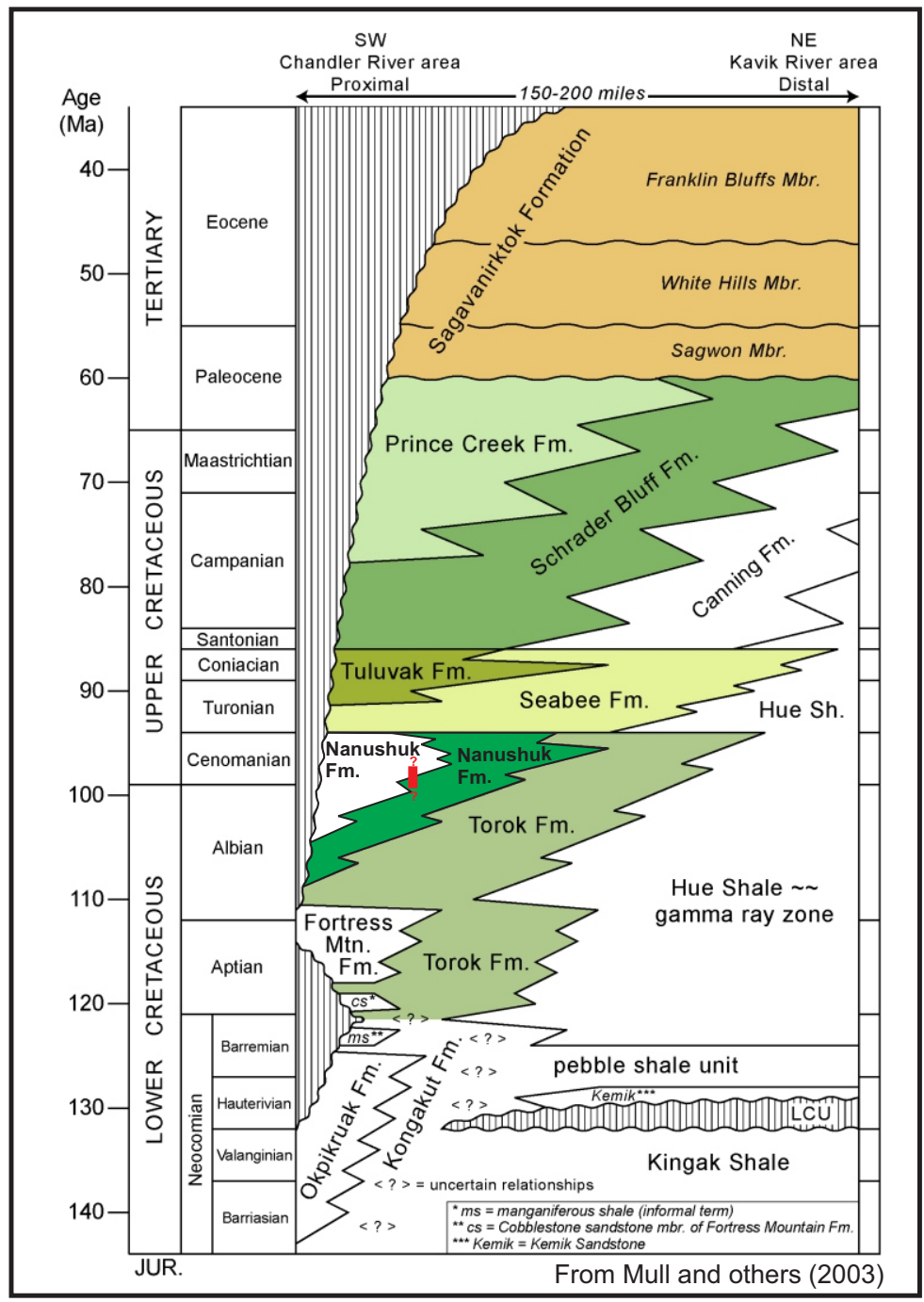

Figure 2-2. Stratigraphic correlation diagram from Mull and others (2003). The vertical red bar in the Nanushuk Formation shows the approximate stratigraphic position of the cored interval in the Wainwright \#1 well. Nanushuk strata shown in green and white represent dominantly marine and dominantly nonmarine strata, respectively. Note this stratigraphic column is for the central North Slope; post-Cenomanian strata have not been recognized in the immediate vicinity of the Wainwright \#1 well.

brandt and others (1979) and Huffman and others (1985) recognized two deltas (complexes), referred to as the Kurupa-Umiat delta and the Grandstand-Marmot delta. These deltas were fed by north-flowing rivers draining smaller catchment areas in the ancestral Brooks Range to the south (Huffman and others, 1985; LePain and others, 2009). Ahbrandt and others (1979) and Huffman and others (1985) interpreted these deltas as river-dominated, but noted a greater degree of wave influence. LePain and others (2009) interpreted these deltas as wave-modified to wave-dominated. Nanushuk strata in the Wainwright \#1 core are part of the Corwin delta complex.

\section{WAINWRIGHT \#1 FACIES}

Twelve facies have been recognized in the Wainwright \#1 core and are summarized in table 2-1. Brief descriptions and interpretations of each are presented below. The degree of bioturbation is characterized using the ichnofabric index of Droser and Bottjer (1986), which ranges from an ichnofabric index of 1 for unbioturbated sediment (here referred to as "II 1") to ichnofabric index of 6 ("II 6") for bedding that is nearly or completely homogenized with no visible traces remaining of original physical sedimentary structures. The facies codes used in this report are adapted from Miall (1996) to accommodate marginal-marine and marine facies. Depths cited in this report are in feet; the thickness of fine-scale stratigraphic features are reported in tenths of feet and the metric equivalent is shown in parentheses.

\section{Fl-LAMINATED MUDSTONE \\ Description}

Facies Fl consists predominantly of dark gray to brown claystone, siltstone, and mudstone characterized by plane-parallel lamination up to 0.15 in (4 mm) thick. Facies Fl commonly displays pronounced fissility (fig. 2-3A). Lamination is typically defined by alternating lighter and darker layers that correspond to slightly coarser and finer grain sizes, respectively (figs. 3A-B). Coarse siltstone to very-fine-grained sandstone is present locally as thin, commonly lenticular, laminae up to 1 in thick $(2.5 \mathrm{~cm}$; figs. $3 \mathrm{~B}-\mathrm{C})$. Convolute laminations are present locally. Thinly interbedded sandstone is a minor component and includes 


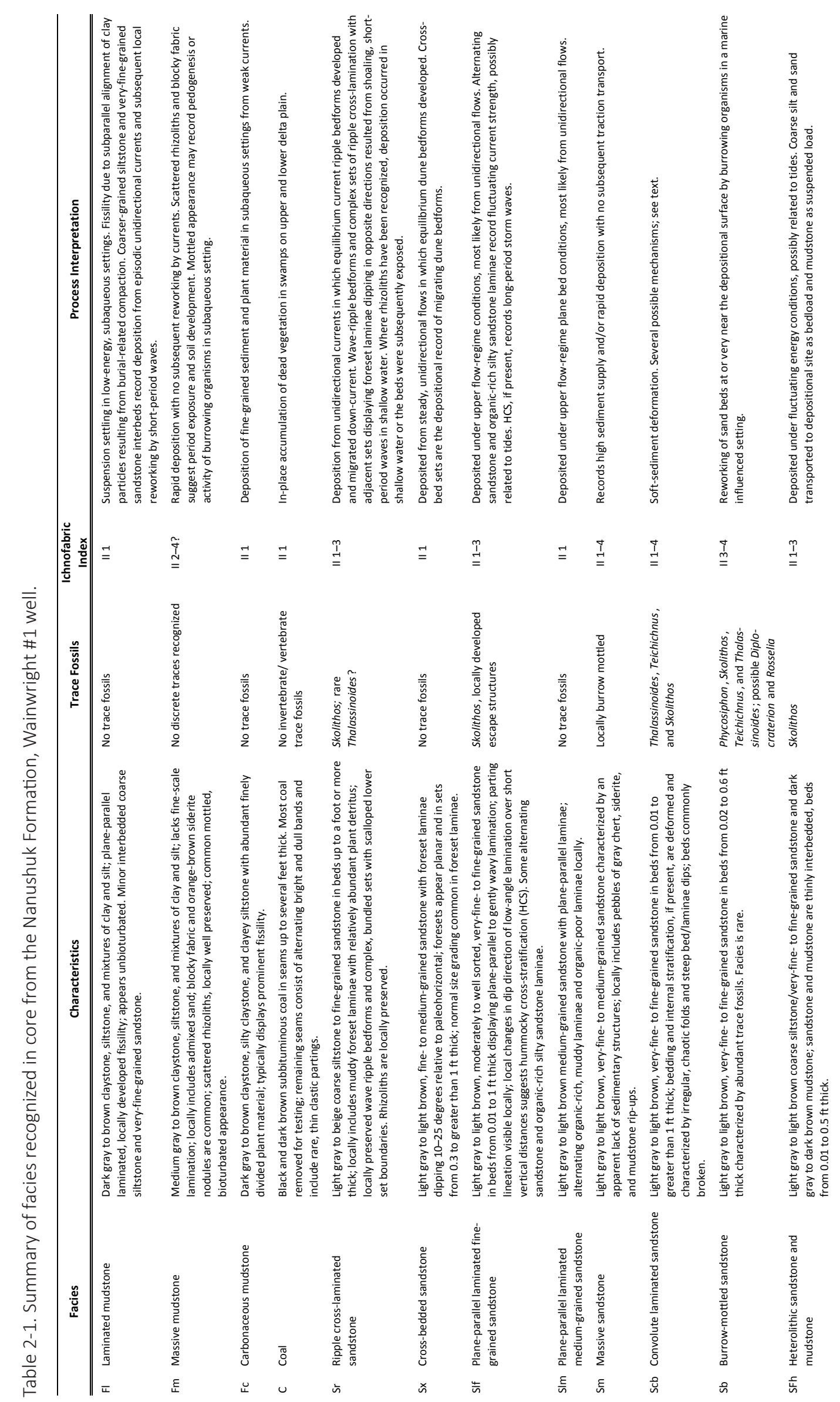



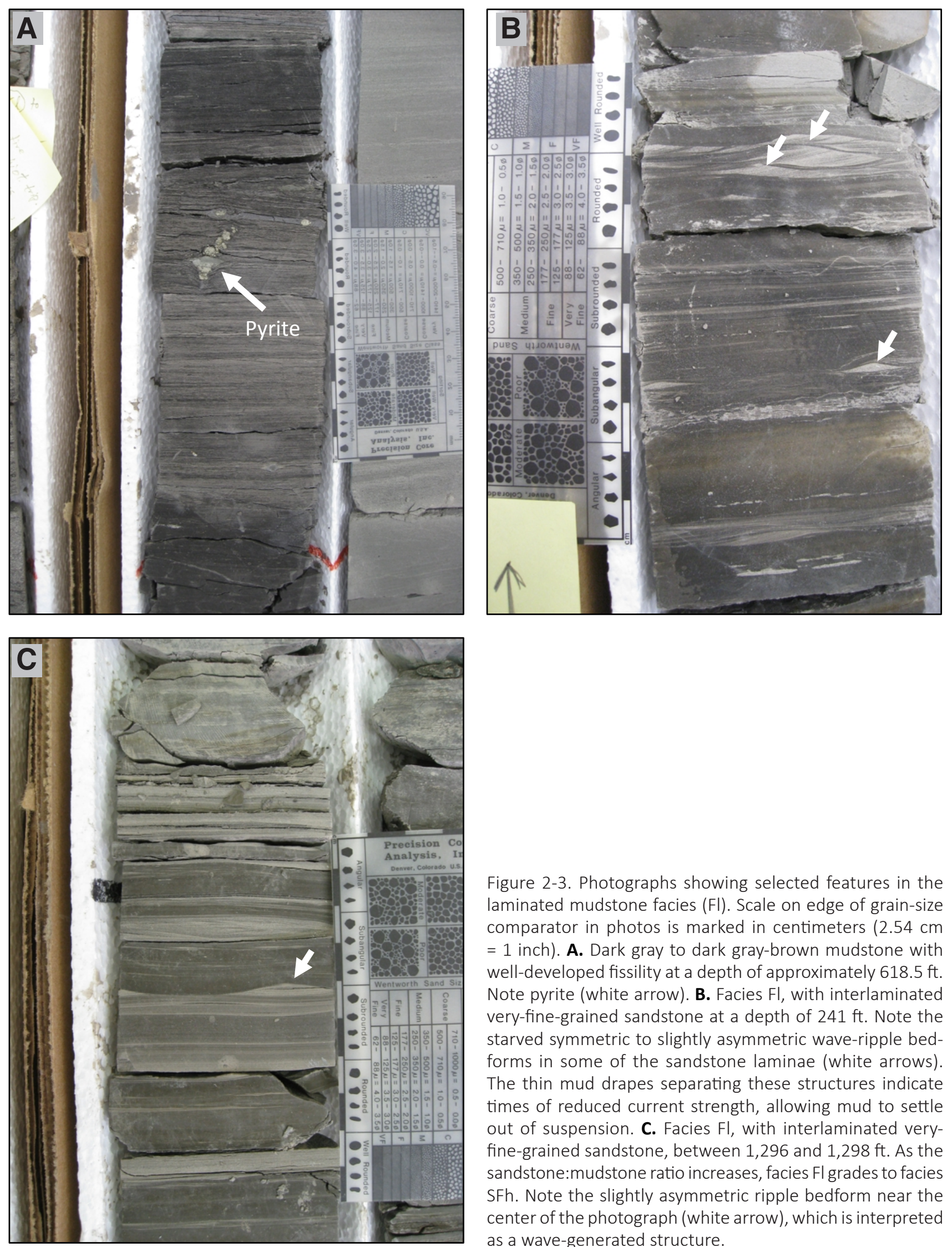

Figure 2-3. Photographs showing selected features in the laminated mudstone facies (FI). Scale on edge of grain-size comparator in photos is marked in centimeters $(2.54 \mathrm{~cm}$ = 1 inch). A. Dark gray to dark gray-brown mudstone with well-developed fissility at a depth of approximately $618.5 \mathrm{ft}$. Note pyrite (white arrow). B. Facies FI, with interlaminated very-fine-grained sandstone at a depth of $241 \mathrm{ft}$. Note the starved symmetric to slightly asymmetric wave-ripple bedforms in some of the sandstone laminae (white arrows). The thin mud drapes separating these structures indicate times of reduced current strength, allowing mud to settle out of suspension. C. Facies Fl, with interlaminated veryfine-grained sandstone, between 1,296 and 1,298 ft. As the sandstone:mudstone ratio increases, facies $\mathrm{FI}$ grades to facies SFh. Note the slightly asymmetric ripple bedform near the center of the photograph (white arrow), which is interpreted as a wave-generated structure. 
plane-parallel lamination, ripple cross-lamination and, less commonly, appears massive. Slightly asymmetrical to symmetrical starved ripple bedforms are locally preserved in some sandstone lenses (white arrows in figs. 3B-C). Nodular siderite and pyrite are minor components of facies Fl (fig. 2-3a). As the number of sandstone interbeds increases, facies $\mathrm{Fl}$ grades to the heterolithic sandstone and mudstone facies (SFh) (fig. 2-3C). Facies Fl appears unbioturbated (II 1).

\section{Interpretation}

Facies Fl records deposition in subaqueous settings characterized by low-energy suspension sedimentation at locations that were beyond the day-to-day influence of higher-energy currents. Fissile mudstone records the subparallel alignment of platy, clay-sized particles resulting from burial and compaction. Plane-parallel laminated siltstone and sandstone record deposition from episodic unidirectional currents, whereas ripple cross-lamination records deposition from migrating two-dimensional current-ripple bedforms under lower-flow-regime conditions (Harms and others, 1975). Local reworking of sand by short-period waves in shallow water resulted in small symmetric to slightly asymmetric wave-ripple bedforms (figs. 3B-C; Collinson and Thompson, 1989). Preservation of fine-scale lamination and the absence of bioturbation indicate deposition in settings hostile to burrowing organisms, possibly due to reduced dissolved oxygen concentrations at or above the sediment-water interface, or a combination of low oxygen and salinity levels.

\section{Fm-MASSIVE MUDSTONE \\ Description}

Facies $\mathrm{Fm}$ consists of medium gray to brown claystone, siltstone, mudstone, and, locally, sandy mudstone. This facies is characterized by a lack of fine-scale lamination and other visible physical sedimentary structures, and lacks well-developed fissility. Facies Fm is locally characterized by a blocky fabric (fig. 2-4A) and commonly includes light orange-brown nodular siderite (fig. 2-4B). Larger siderite accumulations are shown on the core log (sheet 2-1) as siderite bands, which have parallel upper and lower boundaries that appear to conform to bedding. Rhizoliths are present locally (fig. 2-4C). Where present immediately below coal (facies C), facies Fm has a bleached appearance. As in facies $\mathrm{Fl}$, laminae of coarse siltstone to fine-grained sandstone are present locally. As the number of sandstone interbeds increases, facies Fm grades to facies SFh. Discrete trace fossils are generally absent, but the common mottled appearance suggests bioturbation (II 2-4?).

\section{Interpretation}

Most examples of facies Fm record deposition of mudstone in shallow, subaqueous settings removed from sources of coarse-grained sediment. The massive texture resulted from high sedimentation rates from suspension with no subsequent reworking by currents (Collinson,
1968). The sporadic occurrence of moderately bioturbated siltstone and sandstone laminae is consistent with deposition from flood-generated, unidirectional flows that occasionally interrupted this low-energy setting. Examples of this facies that appear bioturbated below a measured depth of 104 feet are interpreted to record deposition in brackish to fully marine settings; examples above this depth record deposition in nonmarine, poorly to moderately drained overbank settings that were subjected to pedogenic modification. Locally developed blocky fabrics and root traces are recognized throughout the cored interval and record disturbance by plants and pedogenic processes (paleosols) operating on intermittently exposed substrates. The blocky fabric (breccia-like in some cases) in the upper part of the core (top of the cored interval to a measured depth of 104 feet) may be related to permafrost or pedogenesis. Siderite precipitated in the shallow subsurface shortly after deposition, and records reducing pore waters and the presence of organic material (Ho and Coleman, 1969; Potter and others, 2005).

\section{FC-CARBONACEOUS MUDSTONE}

\section{Description}

Facies Fc consists of dark gray to dark brown claystone, silty claystone, and clayey siltstone (fig. 2-5A). Abundant finely divided plant material and prominent fissility are principal characteristics. Facies Fc typically includes alternating mudstone and carbonaceous mudstone laminae. An extreme example of this motif consists of alternating thin (up to 1-in- [2-cm-] thick) high-ash coal stringers and laminae of gray fissile mudstone (fig. 2-5B). Nodular siderite is present locally in minor quantities. Trace fossils are absent (II 1).

\section{Interpretation}

Facies Fc records deposition in subaqueous settings distal to sources of coarse-grained sediment. The abundance of fine-grained, well-preserved plant material is consistent with deposition in low-energy settings. Coal stringers record episodic accumulation of allochthonous plant material (up to several inches in pre-compaction thickness) in subaqueous settings that were subsequently buried by fine-grained sediment with less detrital organic material. Abundant plant matter resulted in low dissolved oxygen levels at the sediment-water interface and in the shallow subsurface (Potter and others, 2005), making the setting inhospitable to a burrowing infauna.

\section{C-COAL \\ Description}

Facies $\mathrm{C}$ consists of black to dark brown subbituminous coal in seams a few inches to several feet in thickness. Most coalbeds in the core have been removed (sampled) for various laboratory tests of coalbed methane potential (Clark, 2014). Remaining seams commonly include alternating bright and dull bands up to 0.05 in $(1.3 \mathrm{~mm})$ thick; clastic partings up to $0.05 \mathrm{in}(1.3 \mathrm{~mm})$ thick are present 

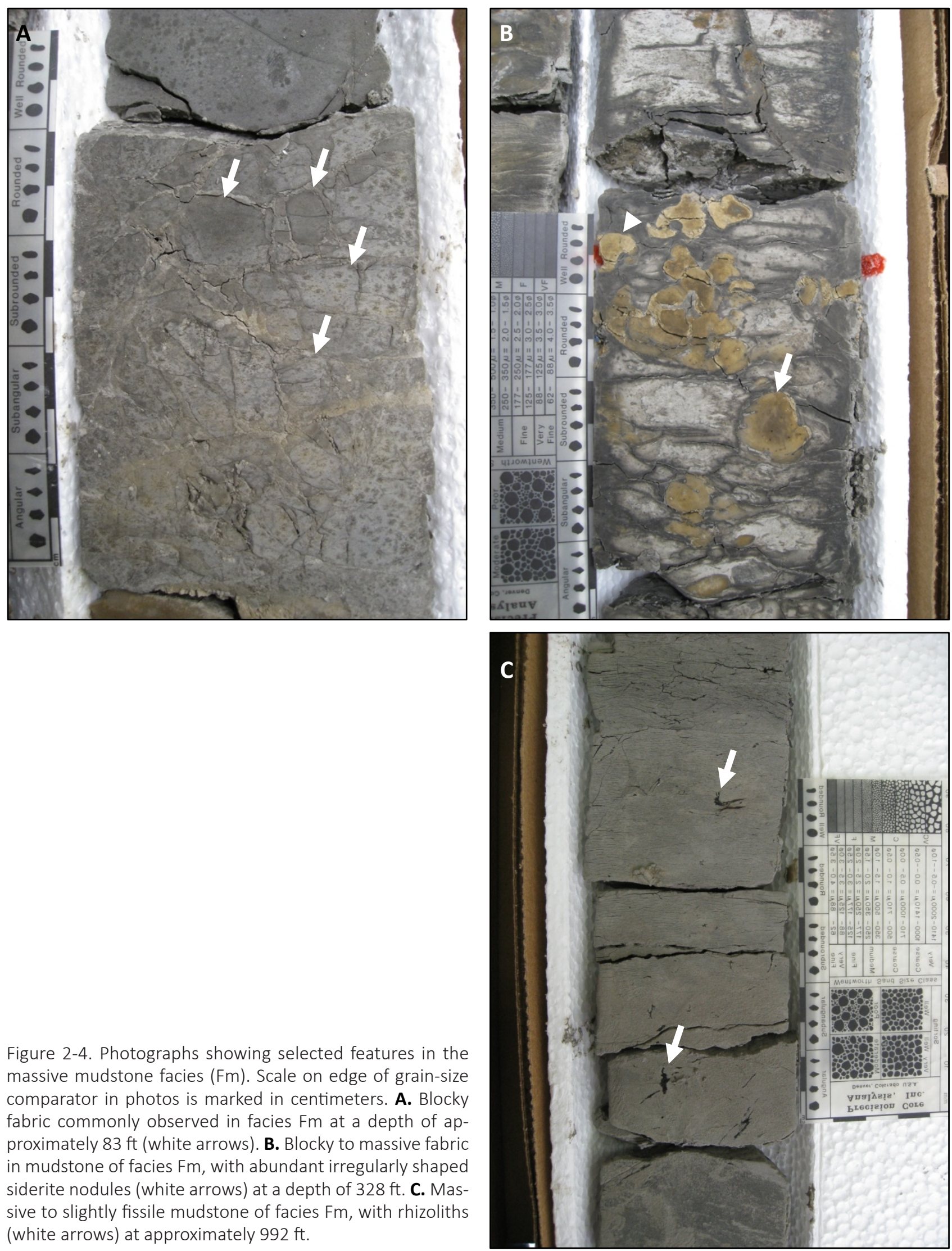

Figure 2-4. Photographs showing selected features in the massive mudstone facies (Fm). Scale on edge of grain-size comparator in photos is marked in centimeters. A. Blocky fabric commonly observed in facies Fm at a depth of approximately $83 \mathrm{ft}$ (white arrows). B. Blocky to massive fabric in mudstone of facies Fm, with abundant irregularly shaped siderite nodules (white arrows) at a depth of $328 \mathrm{ft}$. C. Massive to slightly fissile mudstone of facies $\mathrm{Fm}$, with rhizoliths (white arrows) at approximately $992 \mathrm{ft}$. 

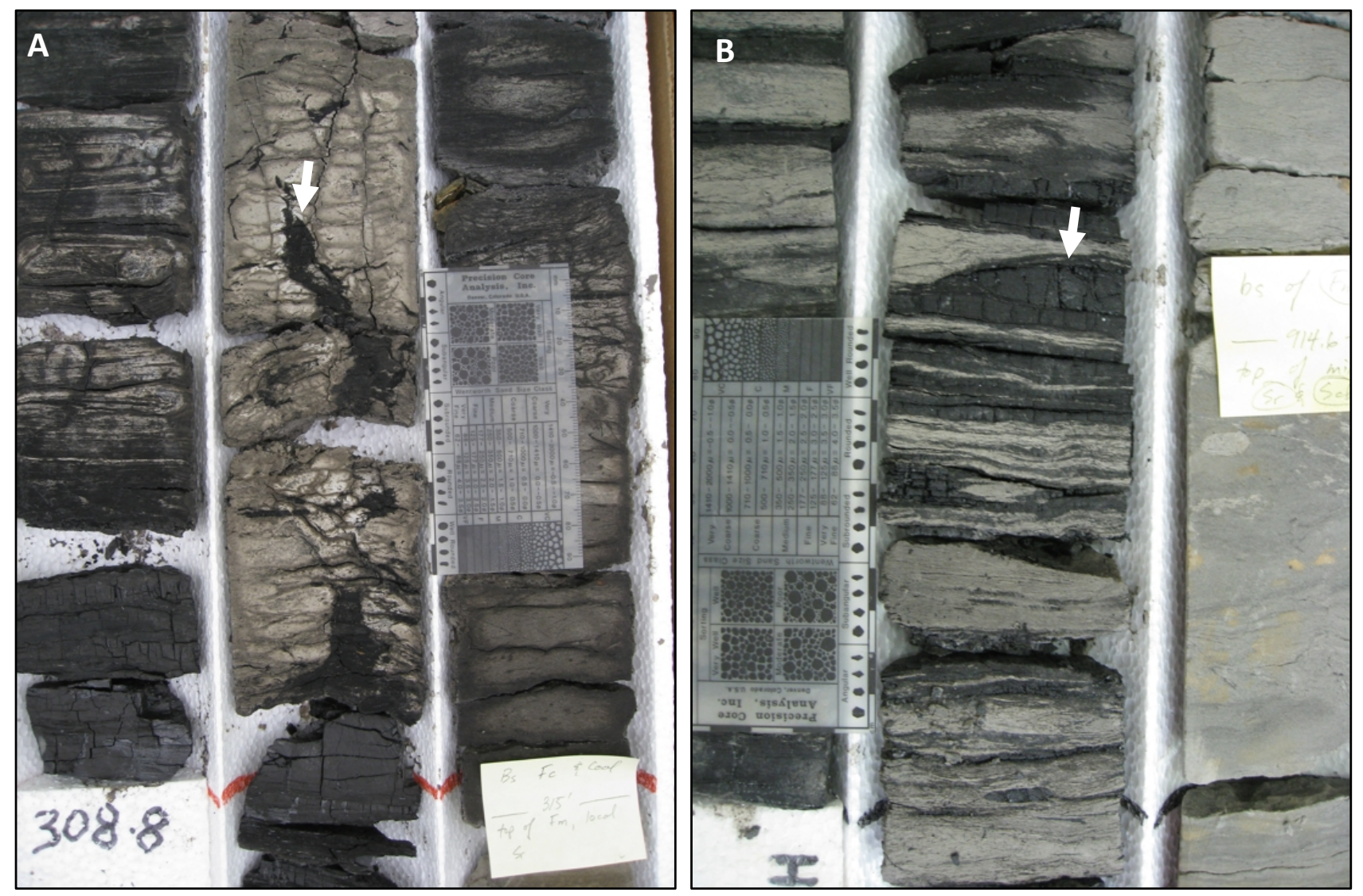

Figure 2-5. Photographs showing selected features in the carbonaceous mudstone facies. Scale on edge of grain-size comparator in photos is marked in centimeters. A. Dark brown carbonaceous mudstone of facies Fc above and below gray massive mudstone (Fm) between 308 and $315 \mathrm{ft}$ depth. Note the large root structure in the gray mudstone filled with dark-brown carbonaceous mudstone (white arrow; facies Fc). B. Interlaminated, fissile mudstone and high-ash coal (white arrow) assigned to facies Fc at a depth of $912 \mathrm{ft}$.

locally. Figure 2-6 shows coalbeds remaining in the core after sampling between 557.7 and $568.1 \mathrm{ft}$.

\section{Interpretation}

Coal records deposition in peat swamps (mires) removed from sources of terrigenous clastic sediment (McCabe, 1984; Galloway and Hobday, 1996). Depositional settings include brackish-water swamps that fringed interdistributary bays on the lower delta plain, and freshwater swamps. The thicker peat accumulations in both settings were protected from active fluvial and distributary channels.

\section{Sr-RIPPLE CROSS-LAMINATED SANDSTONE Description}

Facies Sr consists of light gray to beige coarse siltstone to fine-grained sandstone in beds up to a foot or more thick, with prominent cross-lamination in sets up to $0.2 \mathrm{ft}$ $(6.1 \mathrm{~cm})$ thick. Some sand in facies $\mathrm{Sr}$ is poorly sorted and includes appreciable mud (fig. 2-6, darker brown laminae from 560 to $562.8 \mathrm{ft}$, and fig. 2-7A). Finely divided plant material, where present, is concentrated in muddy foreset laminae (fig. 2-6, $560.5 \mathrm{ft}$, and 7A-B). Mudstone is present as thin drapes up to 0.08 in (2 mm) thick (fig. 2-7C) and thicker interbeds up to a few tenths of a foot thick. Stossside laminae are rarely preserved and set boundaries are typically erosional. Sandstone beds have sharp basal and upper contacts. Simple and complex sets of ripple crosslaminae have been recognized, with the latter consisting of complexly interwoven bundled sets with foresets in adjacent sets dipping in opposite directions and displaying scalloped lower set boundaries (fig. 2-7C). Where mudstone overlies facies Sr, ripple bedforms are locally preserved and display symmetric to slightly asymmetric profiles. Representative sandstone laminae from facies $\mathrm{Fl}$ (figs. 2-3B and 2-3C) show thinly interbedded sandstone that includes small-scale wave-ripple bedforms; where ripple cross-laminated sandstone is the dominant lithology it is assigned to facies Sr. When facies Sr alternates with mudstone beds to form a rhythmic succession it is assigned to facies $\mathrm{SFh}$. Bioturbation ranges from absent (II 1; fig. 2-7B-C) to moderate (II 2-4; fig. 2-7A shows a single escape burrow). Skolithos is most common; Thalassinoides has been recognized in some adjacent beds that may have been ripple cross-laminated prior to disruption by burrowing organisms. 


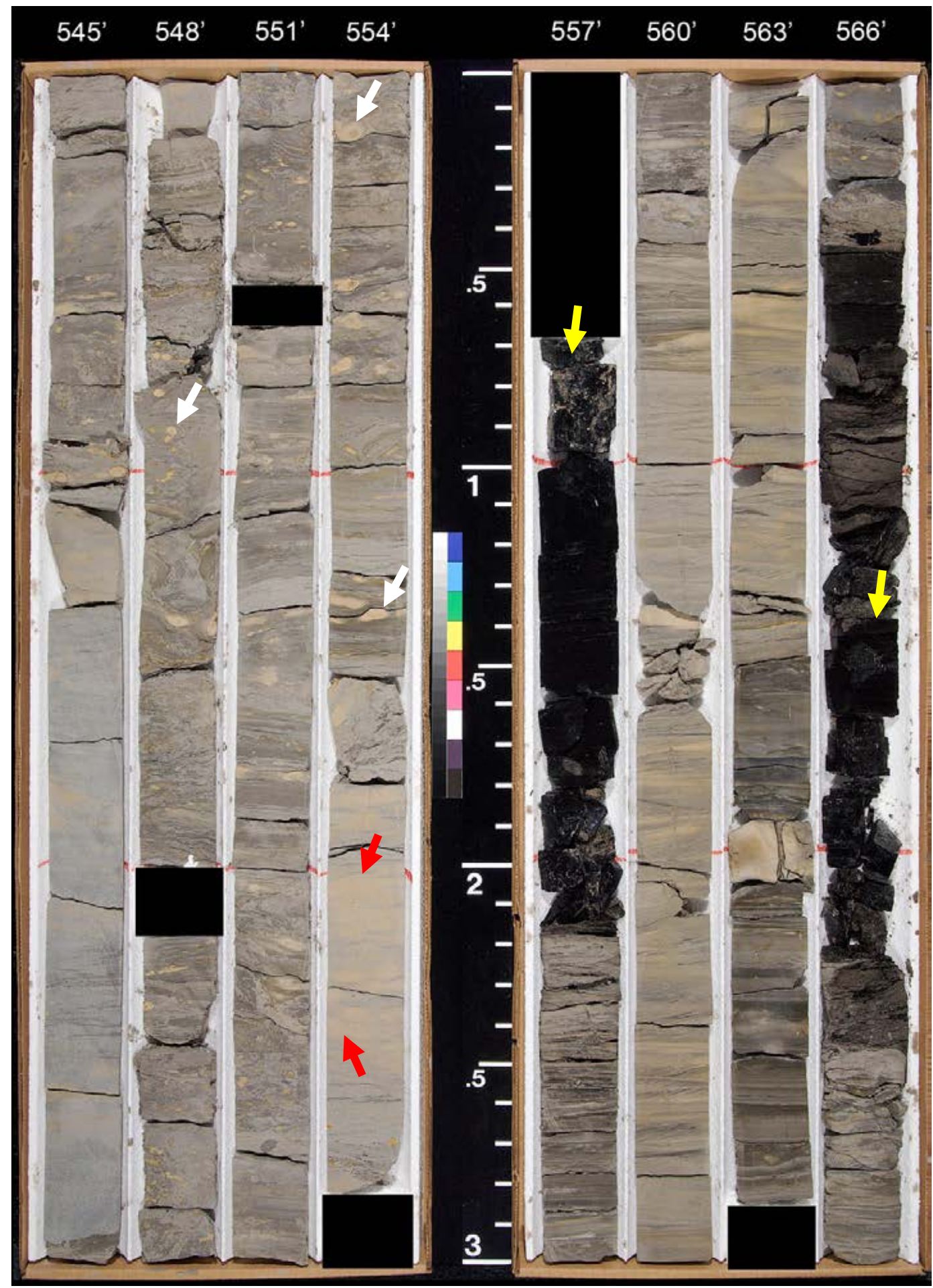

Figure 2-6. Core photograph showing coal between 556.8 and $568.3 \mathrm{ft}$ (yellow arrows), and interbedded mudstone, muddy sandstone, and sandstone with abundant siderite nodules between 545 and $557 \mathrm{ft}$ (white arrows). Note sideritic cement in sandstone from 555.8 to $556.8 \mathrm{ft}$ (red arrows). Note: Each core box holds $12 \mathrm{ft}$ of core in four 3 -ft-long rows; depth in feet is shown at the top of each row. The scale between boxes is marked in feet and tenths of a foot. All core boxes shown in subsequent figures are marked in the same way. 

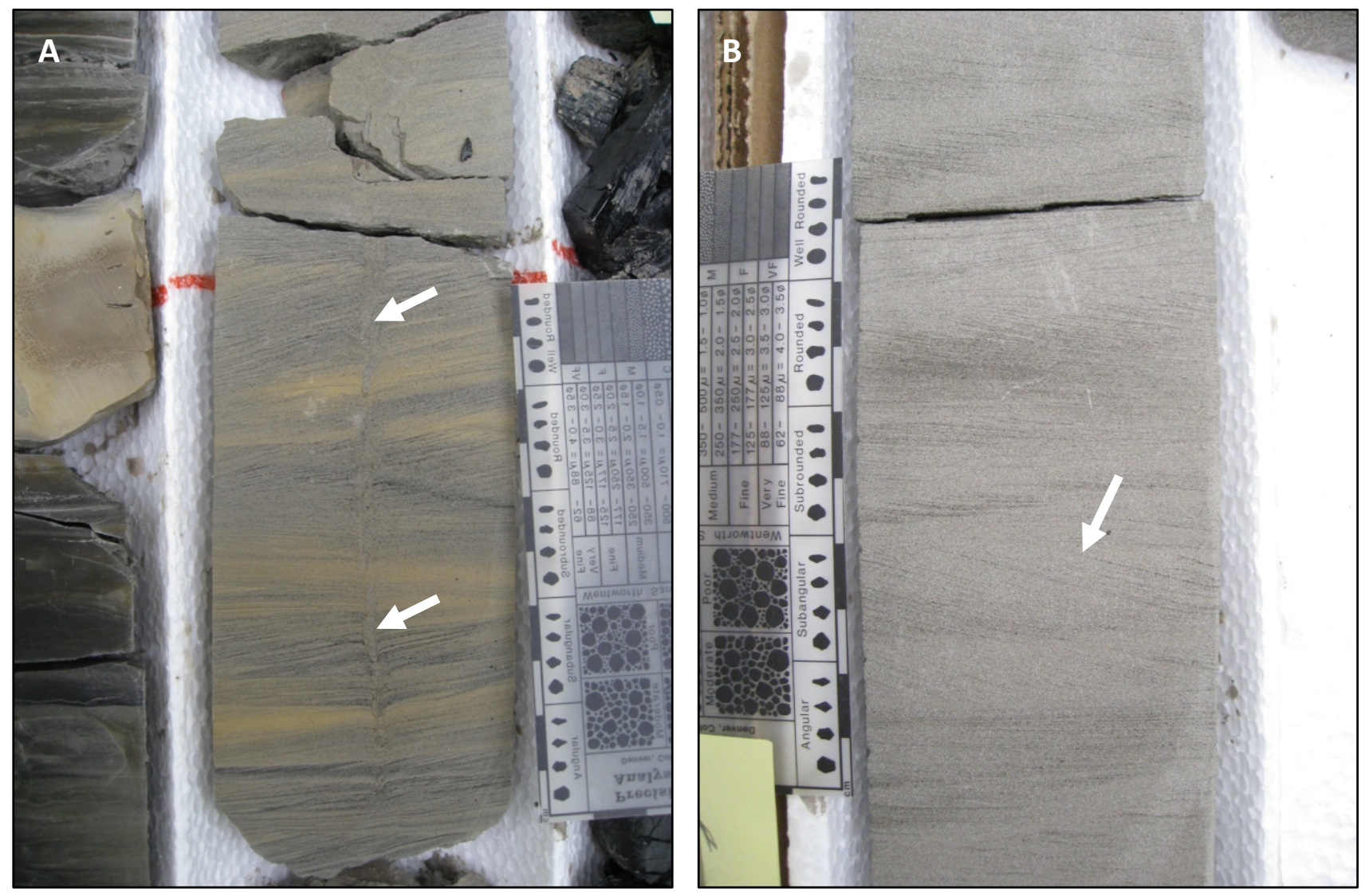

Figure 2-7. Photographs showing selected features in the ripple cross-laminated sandstone facies (Sr). Scale on edge of grain-size comparator in photos is marked in centimeters. A. Stacked sets of ripple cross-laminae penetrated by a single vertical escape burrow between 562 and $565 \mathrm{ft}$ (white arrows; II 2). B. Stacked sets of ripple cross-laminae at a depth of $463.5 \mathrm{ft}$. Stoss-side laminae are not preserved and sets display low climb angles (white arrow). Note muddy foreset laminae (darker-colored laminae). C. Stacked sets of ripple cross-laminae at $687.5 \mathrm{ft}$. Note the complexly interwoven sets with boundaries dipping to the right and left, suggesting a wave origin. Note discontinuous clay drape (white arrow). The lowest set sank into the underlying muddy sand/sandy mud (red arrow) due to a slight density contrast.

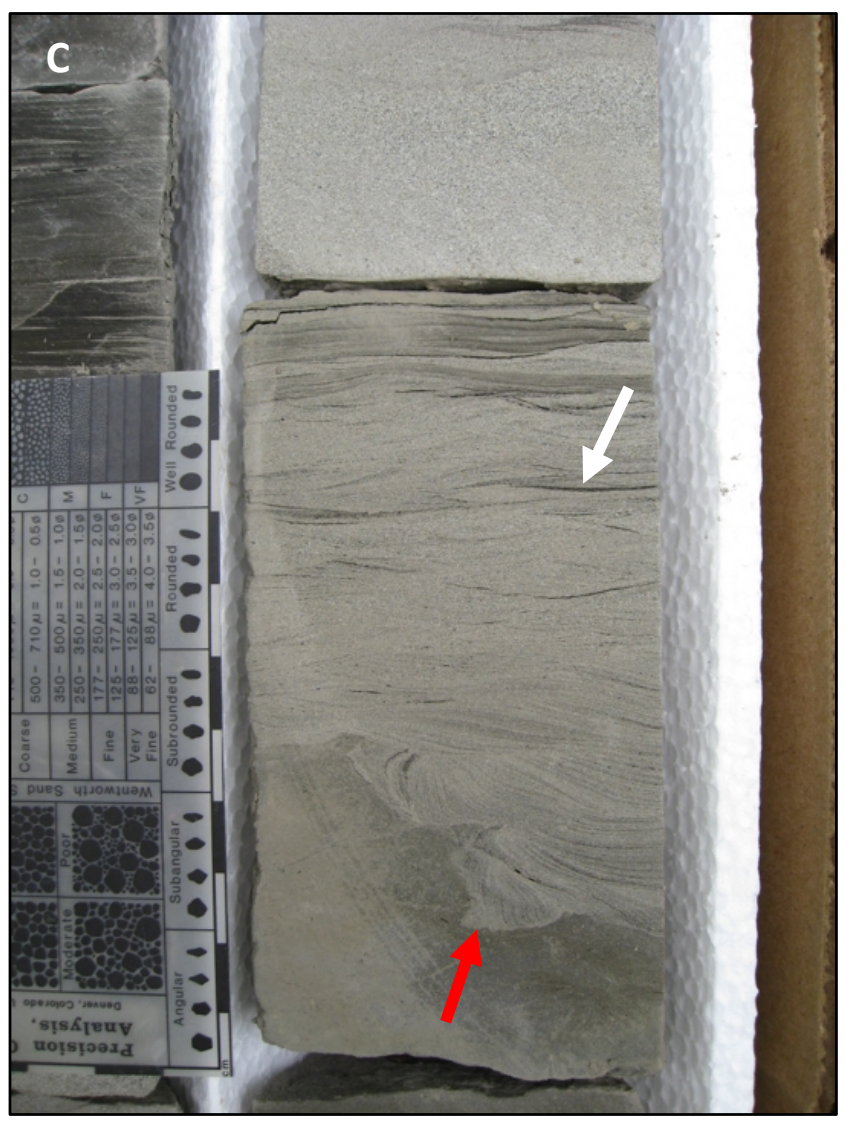




\section{Interpretation}

Ripple cross-laminated sandstone of facies Sr represents the depositional record of small, migrating two-and three-dimensional dunes in a subaqueous setting under lower-flow-regime conditions (Simons and others, 1965; Harms and others, 1975; Allen, 1984). Most cross-lamination in this facies is interpreted as forming initially from unidirectional currents under conditions of relatively low sediment supply such that stoss-side laminae were not preserved (type A ripple drift cross-lamination of Jopling and Walker, 1968; figs. 2-7A-B). Subsequent reworking locally by small, short-period shoaling waves is indicated by preserved small-scale, symmetrical to nearly symmetrical, wave-ripple bedforms (figs. 2-3B and C show examples from facies $\mathrm{Fl}$ ) and the complexly interwoven bundled sets of cross-lamination present in some sand beds (for example, de Raaf and others, 1977; fig. 2-7C).

\section{Sx-CROSS-BEDDED SANDSTONE}

\section{Description}

Facies Sx consists of light gray to light brown, fineto medium-grained sandstone characterized by foreset laminae that dip 10-25 degrees relative to paleohorizontal (figs. 2-8A-B). Foresets appear planar and comprise sets 0.3 $\mathrm{ft}$ to more than $1 \mathrm{ft}(9-30+\mathrm{cm})$ thick. Normal size grading in foreset laminae is common; slight color changes associated with different grain-size fractions and organic debris serve to accentuate foreset stratification. Thin, diffuse pebble lags (1-2 clasts thick) are locally present in facies Sx, usually at or near the base of sets, and consist primarily of sideritic mudstone and mudstone clasts (fig. 2-8B, clasts scattered between 1,088 and 1,095 ft); quartz and chert clasts are present in some lags. Trace fossils have not been recognized in this facies (II 1).
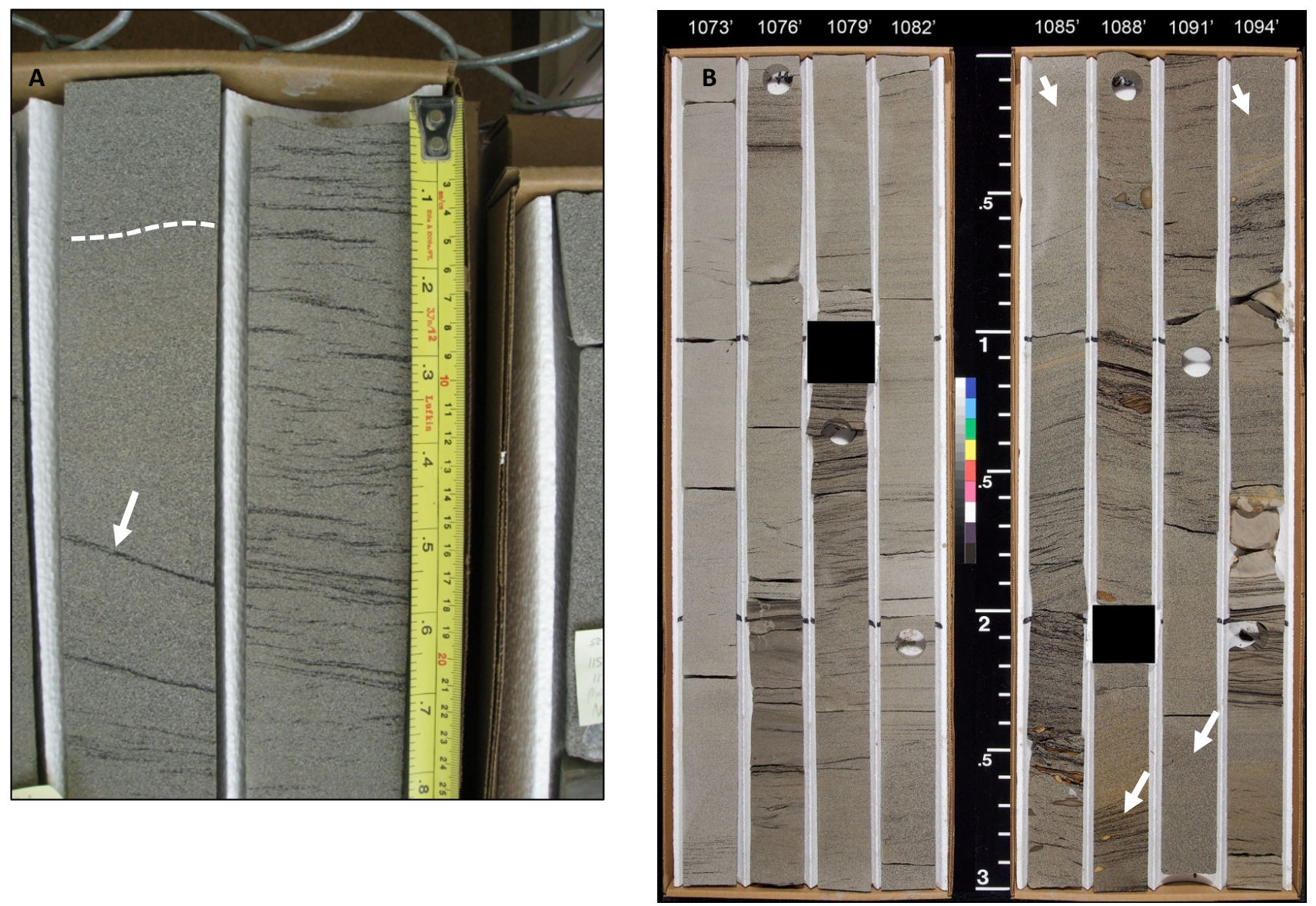

Figure 2-8. Photographs showing selected features in the cross-bedded sandstone facies (Sx). A. Planar foresets in mediumgrained sandstone; some foreset laminae are lined with carbonaceous debris (white arrow; depth approximately 1,151.6 $\mathrm{ft}$ ). Dashed white line marks upper set boundary. Tape measure marked in centimeters (right side) and tenths of a foot (left side). B. Core photo of channel-fill succession between 1,097 and 1,073 ft that includes multiple sets of cross-bedded sandstone (white arrows). 


\section{Interpretation}

Cross-bedded sandstone of facies Sx represents the depositional record of migrating dunes developed in sand in a subaqueous setting in response to unidirectional lower-flow-regime currents (Simons and others, 1965; Harms and others, 1975; Collinson and Thompson, 1989). Planar foresets suggest dunes were characterized by relatively straight crestlines (two-dimensional; Ashley, 1990), but the limited view provided by one core precludes further analysis. Preserved set thicknesses represent only a fraction of original dune heights. Pebbles comprising lags were transported only during events having the highest flow velocities, such as floods. Sideritic mudstone and mudstone clasts were most likely derived from facies Fm and, to a lesser extent, Fc and Fl, as flood currents scoured muddy substrates and entrained iron-rich concretionary masses that were forming at shallow burial depths in adjacent interdistributary bays.

\section{Slf-PLANE-PARALLEL LAMINATED FINE-GRAINED SANDSTONE}

\section{Description}

Facies Slf consists of light gray to light brown, moderately to well sorted, very-fine- to fine-grained sandstone in beds characterized by plane-parallel, flat to gently wavy laminae 0.05 to 0.4 in (1-10 $\mathrm{mm}$ ) thick (figs. 2-9A, C-D). Laminae dipping at low angles that gradually change dip direction up- or down-section over short stratigraphic distances are suggestive of hummocky cross-stratification (fig. 2-9E). Sandstones most commonly have sharp contacts with bounding beds (sandstone and mudstone), but gradational upper contacts with mudstones have been observed. Lamination is commonly defined by subtle grain-size changes and/or the presence of finely divided plant fragments (figs. 2-9A and C); siderite as clasts and in-place cemented zones are present locally. Parting lineation is visible on some parting surfaces. Rarely, facies Slf includes alternating laminae of sandstone and organic-rich silty sandstone that gradually change thickness and abundance in vertical succession, forming a repetitive motif (fig. 2-9D, from $1,102.7$ to $1,099.2 \mathrm{ft}$ ) that is gradational to facies SFh. Bioturbation ranges from absent (II 1) to moderate (II 3-4); most beds are either unbioturbated or only sparsely bioturbated with Skolithos. Some vertical traces are likely escape structures.

\section{Interpretation}

Plane-parallel lamination and parting lineation in sandstones of facies Slf record deposition under upperflow-regime plane bed conditions (Simons and others, 1965; Harms and others, 1975; Allen, 1984), most likely from unidirectional currents. Alternating laminae of sandstone and organic-rich silty sandstone record fluctuations in current velocity from higher velocity, when finer material (silt and small plant fragments) was maintained in suspension or winnowed from the depositional interface, to lower velocity when silt and organic material carried in suspension settled with minimal subsequent transport. Alternating current strength may have resulted from tides (Dalrymple, 1992).

\section{Slm-PLANE-PARALLEL LAMINATED MEDIUM-GRAINED SANDSTONE}

\section{Description}

Facies Slm shares characteristics in common with facies Slf, but is coarser grained and lacks bioturbation (II 1). It consists of light gray to light brown-gray, moderately to well sorted, fine- to medium-grained sandstone characterized by plane-parallel, flat laminae from 0.04 to 0.5 in (1-13 mm) thick (figs. 2-9B and D, white arrows). Alternating laminae of organic-rich, muddy sandstone and organic-poor, mud-free sandstone are locally present.

\section{Interpretation}

Plane-parallel lamination in facies Slm records deposition under upper-flow-regime plane bed conditions associated with unidirectional currents (Simons and others, 1965; Southard, 1971; Harms and others, 1975; Allen, 1984). The coarser grain size and apparent low detrital mud content characteristic of this facies indicate deposition from higher-velocity currents than were responsible for facies Slf, which did not allow mud and finer-grained sand to settle out of suspension. As in facies Slf, locally occurring, interlaminated, organic-rich, muddy sandstone and organic-poor, mud-free sandstone suggest deposition from rhythmically alternating lower-energy and higherenergy flows, possibly associated with tides. The absence of trace fossils is consistent with deposition in high-energy settings characterized by fresh or low-salinity brackish water.

\section{Sm-MASSIVE SANDSTONE \\ Description}

Facies Sm consists of light gray to light brown, veryfine- to medium-grained sandstone in beds 0.01 to $1.0 \mathrm{ft}$ $(0.3-30 \mathrm{~cm})$ thick characterized by an apparent lack of sedimentary structures (fig. 2-10). Sandstones of this facies have sharp bounding contacts with underlying facies, whereas the upper contact with mudstone can be sharp or gradational. Plant fragments ranging in size from coffee grounds (fine sand-size) to greater than $0.1 \mathrm{ft}(3 \mathrm{~cm})$ are present locally as thin, discontinuous drapes. Pebbles are present locally and include light gray chert, siderite, and mudstone rip-ups (fig. 2-10). Thin siderite-cemented zones or bands are also present. Bioturbation ranges from absent (II 1) to moderate (II 3-4). Where bioturbation is present, discrete traces of known affinity have not been identified.

\section{Interpretation}

Facies Sm is interpreted to record rapid deposition with limited or no subsequent traction transport sufficient for equilibrium bedforms to develop (Collinson, 1968; Bhattacharya and Walker, 1991). It is possible that grain- 

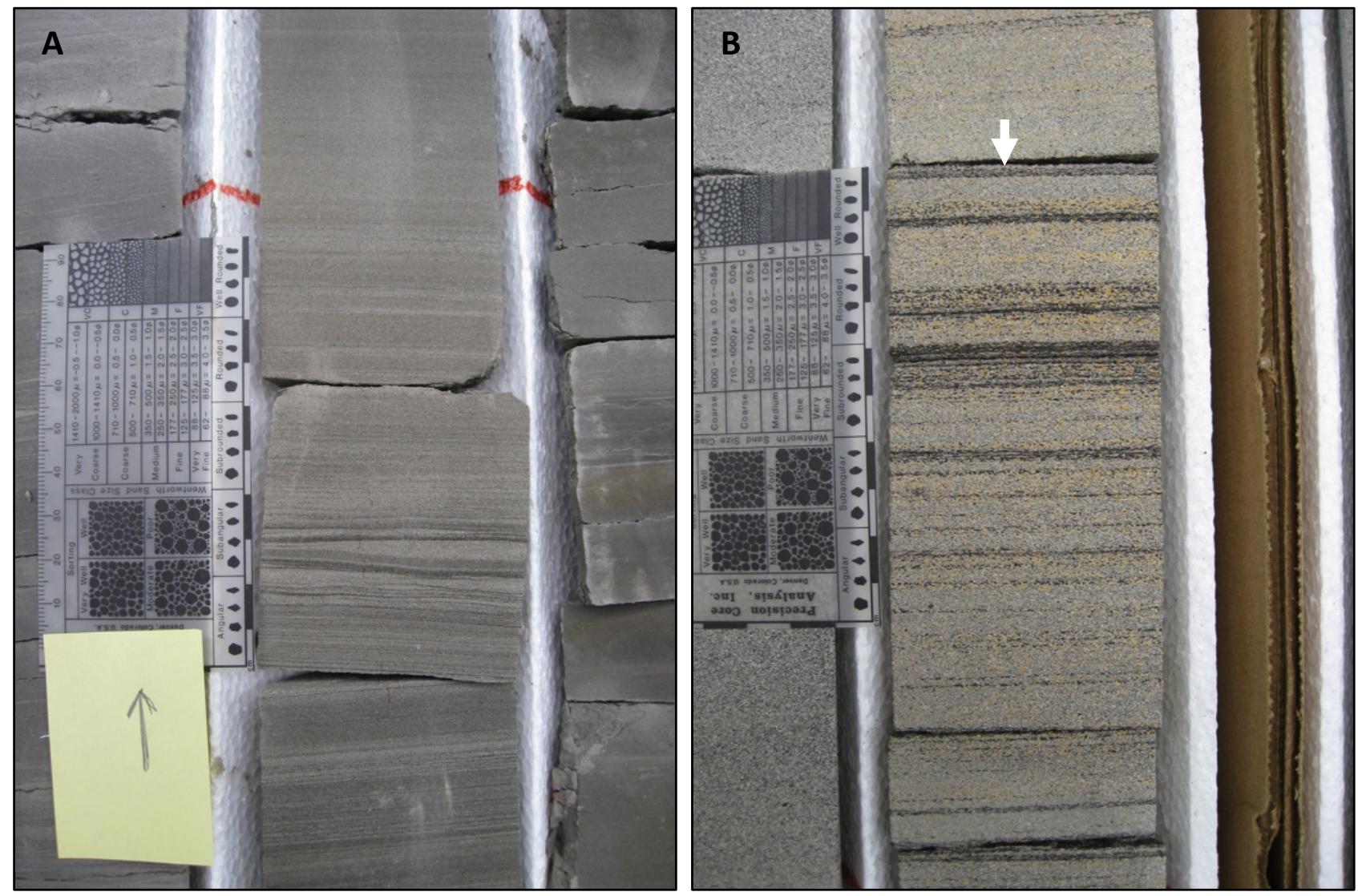

Figure 2-9. Photographs showing selected features in the plane-parallel laminated sandstone facies (SIf and SIm). Scale on edge of grain-size comparator in photos $\mathrm{A}-\mathrm{C}$ is marked in centimeters. A. Well-developed plane-parallel laminae in facies Slf near $624 \mathrm{ft}$ (red line on core tray). B. Planeparallel lamination in facies SIm at $651.5 \mathrm{ft}$ (white arrow). Dark-colored laminae are rich in carbonaceous debris. C. Plane-parallel laminae disrupted by small-scale normal faults at approximately 1,318.3 ft (white arrow) in facies Slf.

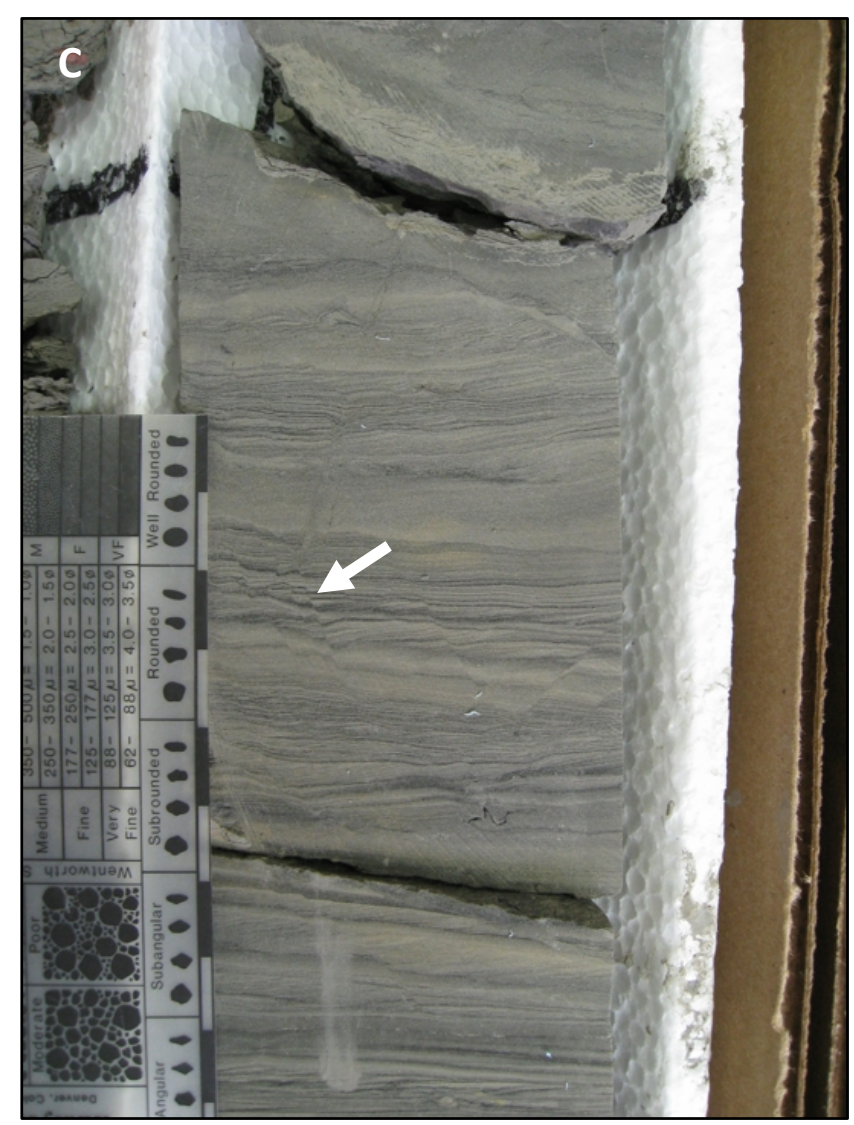



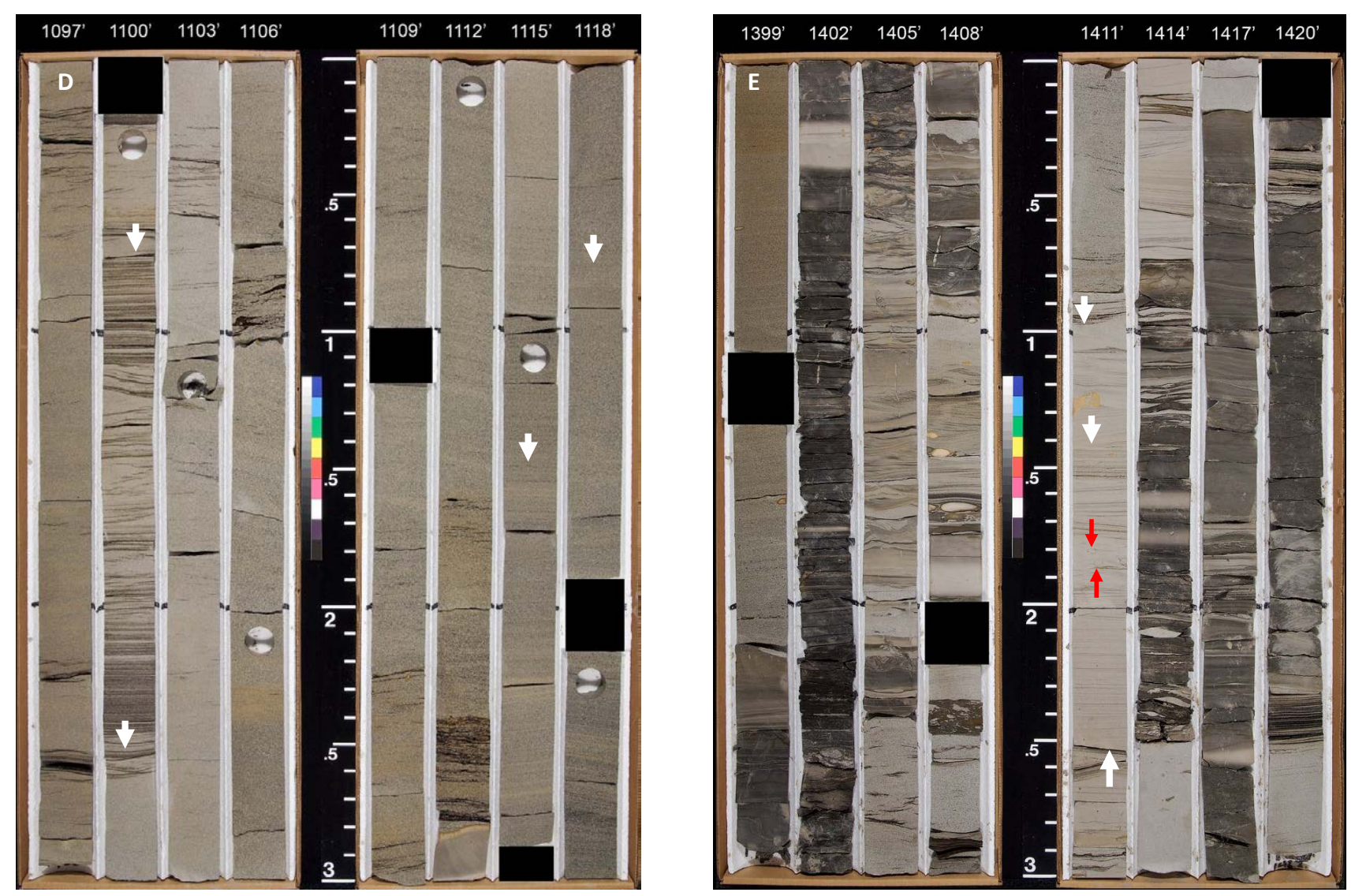

Figure 2-9 (continued). Photographs showing selected features in the plane-parallel laminated sandstone facies (SIf and SIm). D. Plane-parallel laminated sandstone (facies SIm) in a channel-fill succession between 1,100.7 and 1,102.5 ft (white arrows). E. Possible hummocky cross-stratification between 1,412 and 1,413.5 feet (white arrows). Red arrows show possible Paleophycos burrows.

Figure 2-10. Photograph showing massive sandstone (facies $\mathrm{Sm}$ ) at a depth of 1,157 ft. The contact at 1,157.8 ft (red arrow) marks the base of a thick, amalgamated channel complex (amalgamated distributary channel fills) that extends upsection to a depth of $1,060.5 \mathrm{ft}$. Note chert pebble (white arrow). The distributary channel fill truncates disrupted sandy siltstone interpreted as subaqueous levee deposits (below chert pebble and in core on right side of photo). Tape measure marked in centimeters along right edge and tenths of a foot along left edge.

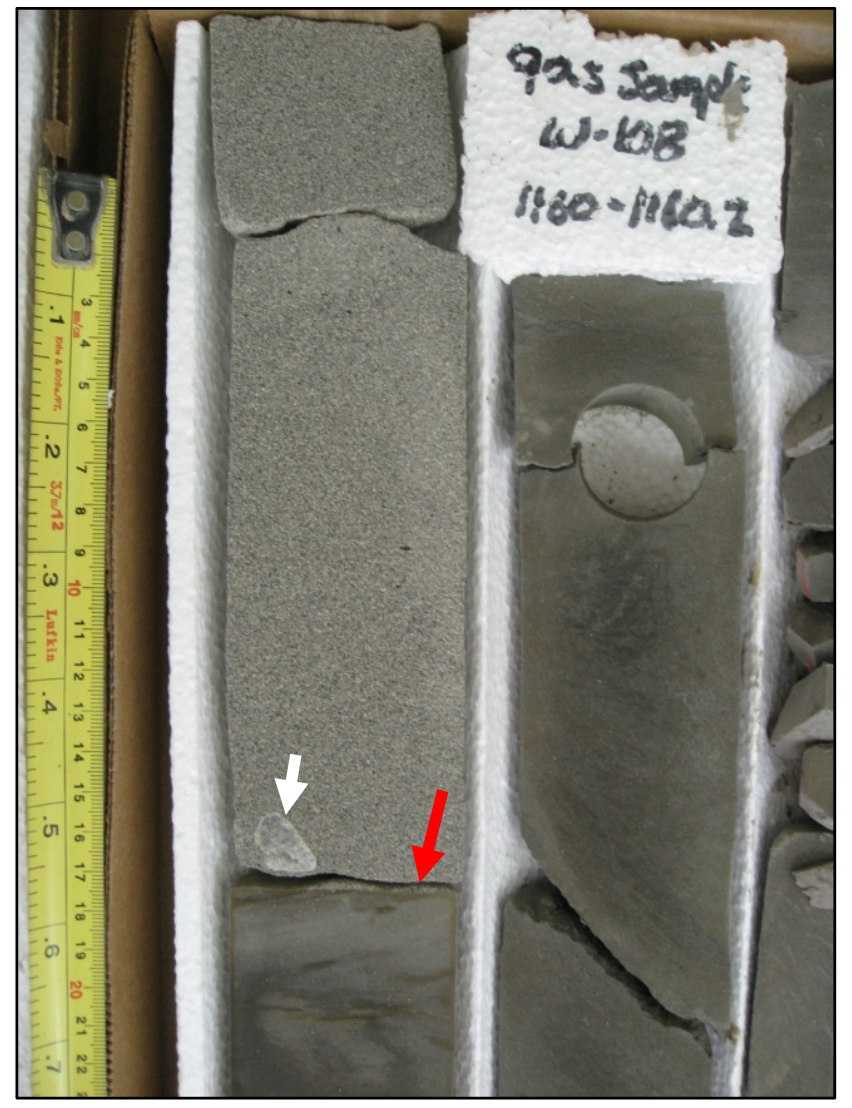


size contrasts and compositional variations are so slight in this facies that sedimentary structures are effectively masked. Without other investigative tools, this possibility is difficult to test.

\section{Scb-CONVOLUTE LAMINATED SANDSTONE Description}

Facies Scb consists of light gray to light brown, very-fineto fine-grained sandstone in beds less than $0.01 \mathrm{ft}$ (much less than $1.0 \mathrm{~mm})$ thick to greater than $1.0 \mathrm{ft}(30 \mathrm{~cm})$ thick that are characterized by deformed laminae (figs. 2-11A-E). Sandstones typically have sharp bounding contacts with mudstones or other sandstone beds; however, gradational upper contacts with muddy lithologies are present. Deformation includes steeply dipping, wavy laminae, tight upright and recumbently folded laminae, broken laminae, detached and folded masses of sandstone encased in mudstone and siltstone (figs. 2-11D-E), and a variety of combinations of these deformation styles. Deformation typically results in a chaotic appearance that is accentuated by the presence of interlaminated mudstone. Original sedimentary structures are recognizable and include plane-parallel lamination and ripple cross-lamination; massive laminae are also present (fig. 2-11E). Siderite as clasts and irregular-shaped nodules is present locally. Bioturbation ranges from absent (II 1) to moderate (II 3-4). Trace fossils include Phycosiphon (and/or Helminthopsis), Rhizocorallium, Skolithos, Teichichnus, Thalassinoides, and Planolites. No single bed includes all of these traces and most beds include only a few genera.

\section{Interpretation}

Facies Scb records sand beds that were originally deposited as facies Sr, Sl, and Sm and subsequently deformed prior to lithification. Plausible deformation mechanisms include: (1) subaqueous deposition of sand on lower-density, uncompacted mud and subsequent foundering of the sand bed (Allen, 1984); (2) subaqueous deposition of sand on an inclined surface and subsequent deformation from downslope creep and/or sliding (Allen, 1984); (3) subaqueous sand deposition and subsequent deformation by gas escaping from underlying mud with decaying terrestrial plant material (Coleman and others, 1964); (4) sand deposition and subsequent deformation by large organisms (such as dinosaurs-"dinoturbation"; Fiorillo and others, 2010); (5) subaqueous sand deposition and subsequent deformation from frictional drag at the interface between a sandy bedform and an overlying moving water column (Allen, 1984); and (6) seismogenic shaking (Greb and Dever, 2002). Given the nature of sediment deformation in the Wainwright core, each of the first three mechanisms could have contributed, at least locally, to soft-sediment deformation features recognized in this facies. The fourth mechanism-deformation by large organisms (dinosaurs)-was clearly operating in nonmarine and very shallow marginal marine settings on the North Slope during middle Albian time, as recently documented by Fiorillo and others (2010). Mechanisms 1, 3 , and 4 most likely contributed to some soft-sediment deformation features observed in the Wainwright core. Deformation by frictional drag is considered unlikely, judging from a lack of preferred orientation of bed dips. Given the tectonic setting (foreland basin), mechanism 6 is possible but difficult to test.

\section{Sb-BURROW-MOTTLED SANDSTONE \\ Description}

Facies Sb consists of light gray to light brown, veryfine- to fine-grained sandstone in beds 0.02 to $0.6 \mathrm{ft}$ $(0.6-18.3 \mathrm{~cm})$ thick, characterized by burrowed fabrics. Bounding contacts with other beds are typically sharp. This facies is differentiated from the other sandy facies by the higher degree of bioturbation: beds are typically moderately to highly bioturbated (II 3-4; fig. 2-12). Recognizable traces include Phycosiphon, Skolithos Teichichnus, and Thalassinoides. Diplocraterion and Rosselia may be present in some beds. Reburrowed traces are present locally (fig. 2-12, Phycosiphon in Teichichnus). Facies Sb is rare in the Wainwright \#1 core.

\section{Interpretation}

Facies Sb records reworking of sand beds at or very near the depositional surface by burrowing organisms. The trace fossils recognized are all common in shallow marine shoreface and proximal shelf settings (Cruziana and Skolithos ichnofacies assemblages; Pemberton and others, 1992), and the genera recognized define a relatively moderate- to high-diversity assemblage. This suggests colonization of sandy substrates in subaqueous settings characterized by hospitable conditions for a burrowing infauna. We interpret this facies to record pauses in sedimentation or complete abandonment of depositional sites following storm events in marine-influenced settings characterized by near normal to normal marine salinities (MacEachern and others, 2007a; Howard, 1975).

\section{Sfh-HETEROLITHIC SANDSTONE AND MUDSTONE}

\section{Description}

Facies SFh consists of a heterolithic association of thinly interbedded light gray to light brown very-fineto fine-grained sandstone and dark gray to dark brown mudstone. Sandstone and mudstone beds range from less than 0.01 to $0.5 \mathrm{ft}(0.3-15.2 \mathrm{~cm})$ thick and alone each would be assignable to one of the sandstone facies (Slf, $\mathrm{Sr}$, or Sm) or mudstone facies (Fl or Fm) described above (except facies C; figs. 13A-E). Sandstone contacts with underlying mudstone are sharp and range from wavy planar (figs. 13C-E) to irregular (figs. 13A-B); upper contacts range from sharp to gradational and many sandstone beds are normally graded (fig. 2-13D). The presence of gutter casts attests to the erosive nature of some of the flows that 

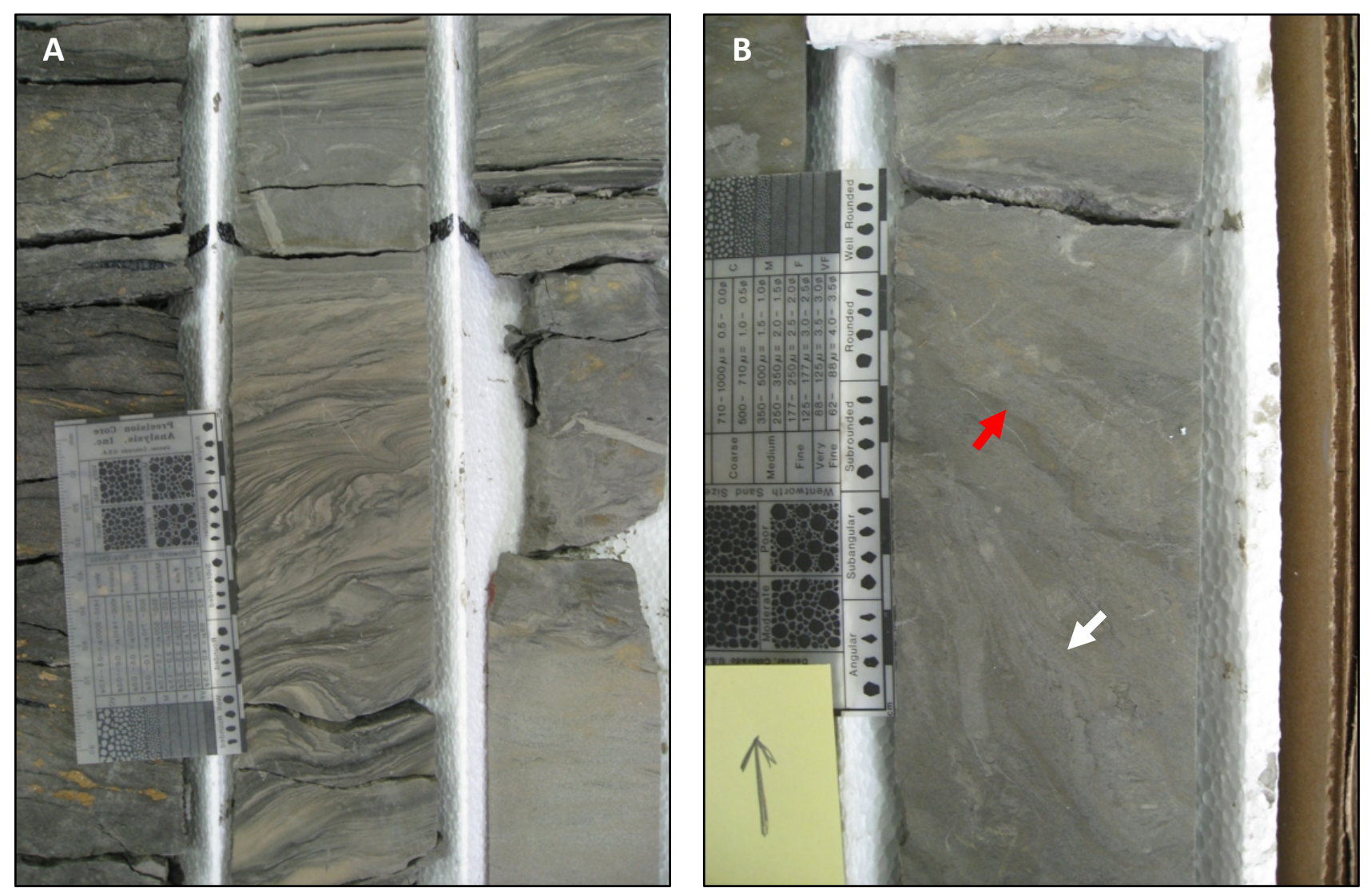

Figure 2-11. Photographs showing selected features in the convolute-bedded sandstone facies (Scb). Scale on edge of grain-size comparator in all photos is marked in centimeters. A. Convolute-bedded sandstone at a depth of 1,487 ft (black line in middle core tray). In its undeformed state this sand was likely plane-parallel laminated. B. Steeply dipping rumpled laminae in muddy sandstone (white arrow) at a depth of approximately $1,210.4 \mathrm{ft}$. Note possible small-scale fault offsets (at and to the right of red arrow). C. Deformed mudstone and sandstone at a depth of 1,219.5 ft. Note the vertical escape burrow filled with sandstone in the laminated interval above the deformed package (white arrow). Note also the smallscale high-angle reverse fault (red arrow).

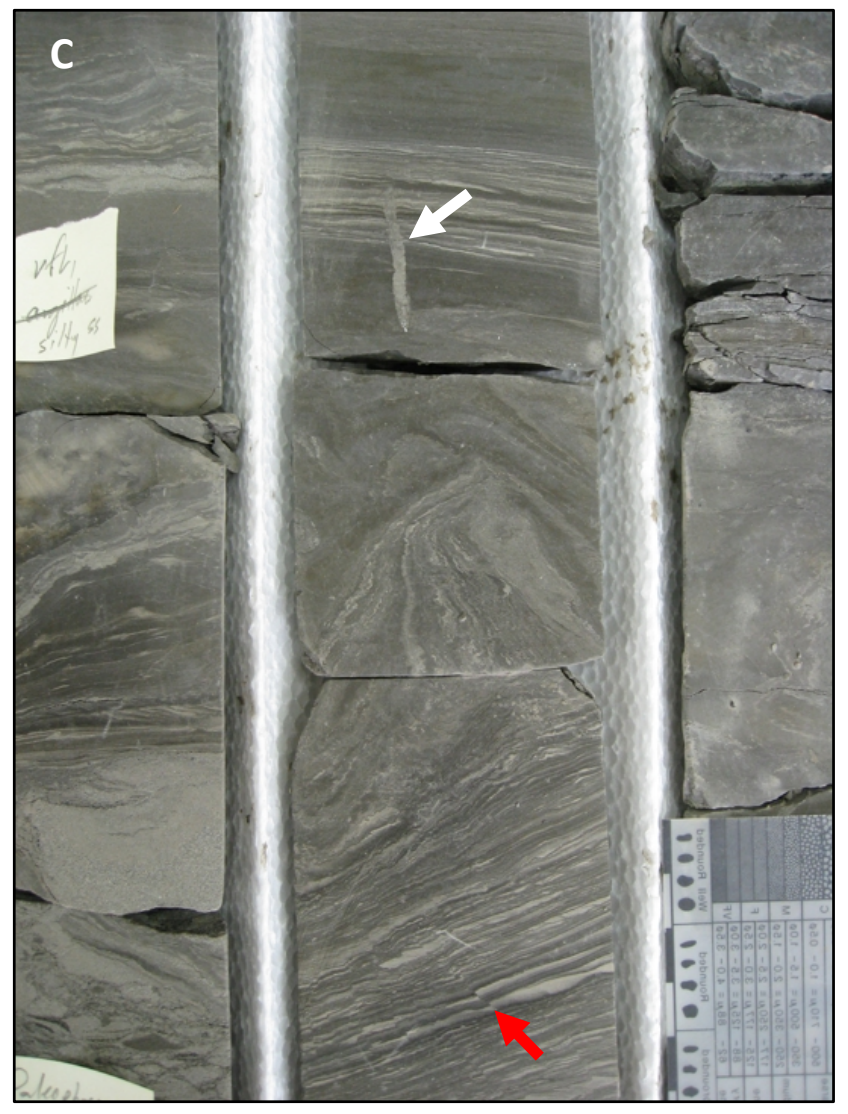



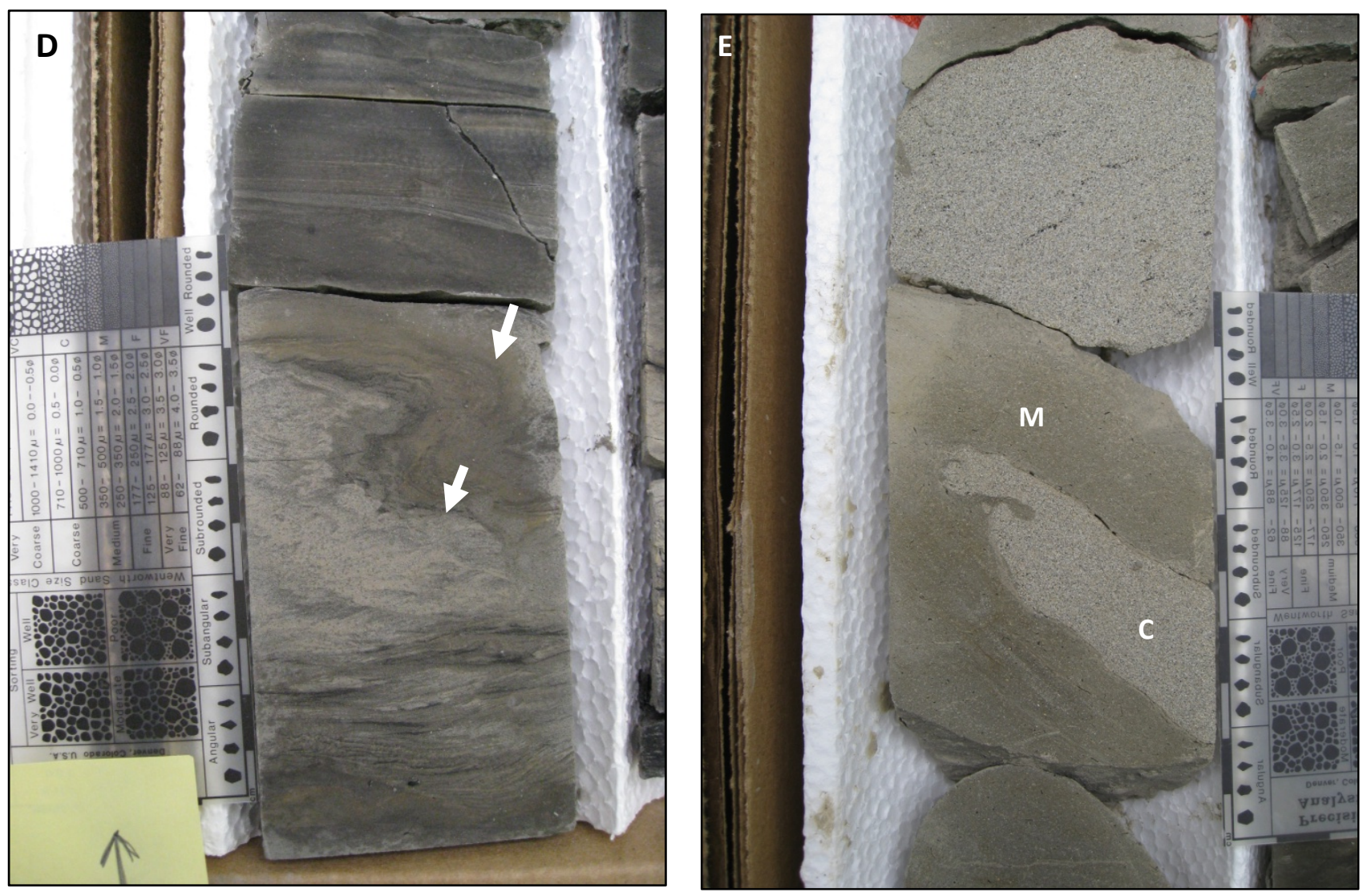

Figure 2-11 (continued). Photographs showing selected features in the convolute-bedded sandstone facies (Scb). Scale on edge of grain-size comparator in all photos is marked in centimeters. D. Convolute bedded mudstone and sandstone (white arrows) at a depth of $114.5 \mathrm{ft}$. E. Finger-shaped protrusion of clean sandstone (white C) that projects upward into muddy sandstone (white M) at a depth of $595.5 \mathrm{ft}$.

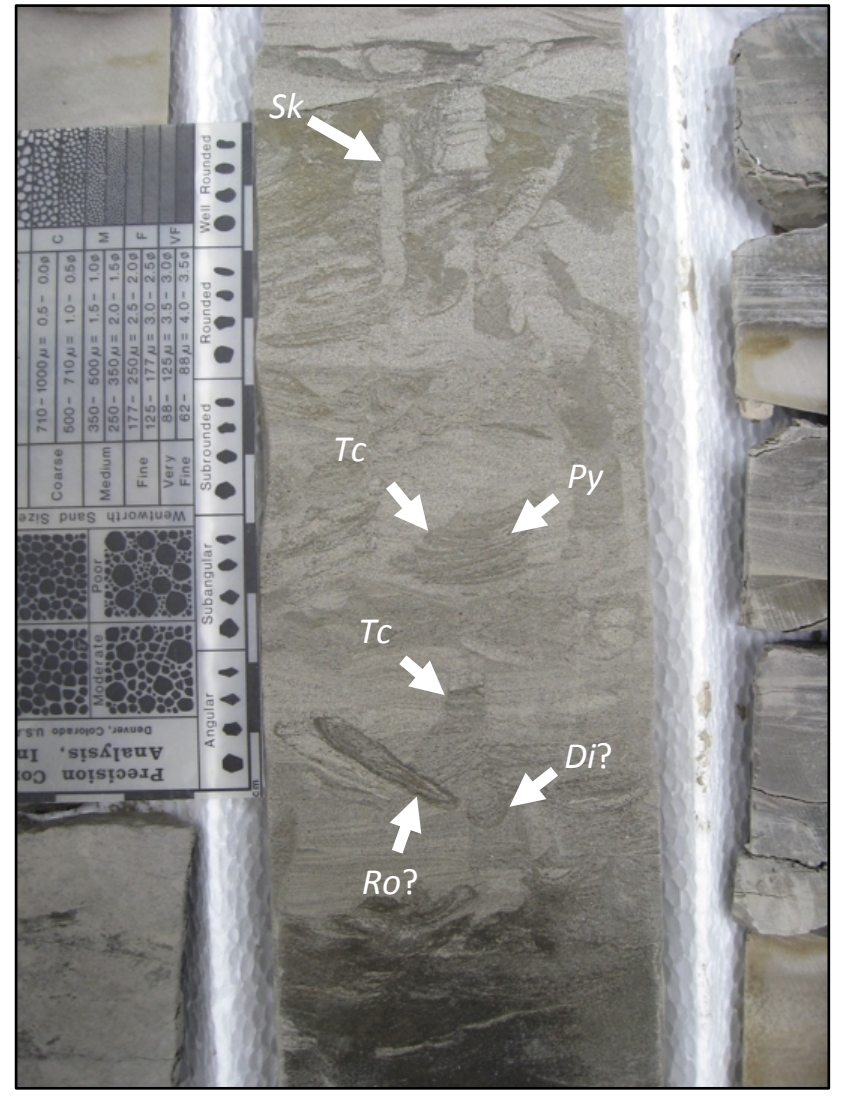

Figure 2-12. Photograph showing selected features in the burrow-mottled sandstone facies (Sb). Scale on edge of grain-size comparator in photo is marked in centimeters. Bioturbated sandstone at a depth of $717.5 \mathrm{ft}$ (II 4) shows visible trace fossils, including Teichichnus (Tc), Skolithos (Sk), Phycosiphon (Py) (or Helminthopsis); and possible Diplocraterion (DI) (some Skolithos could be Diplocraterion) and Rosselia (Ro). Note Phycosiphon or Helminthopsis traces within Techichnus traces. 

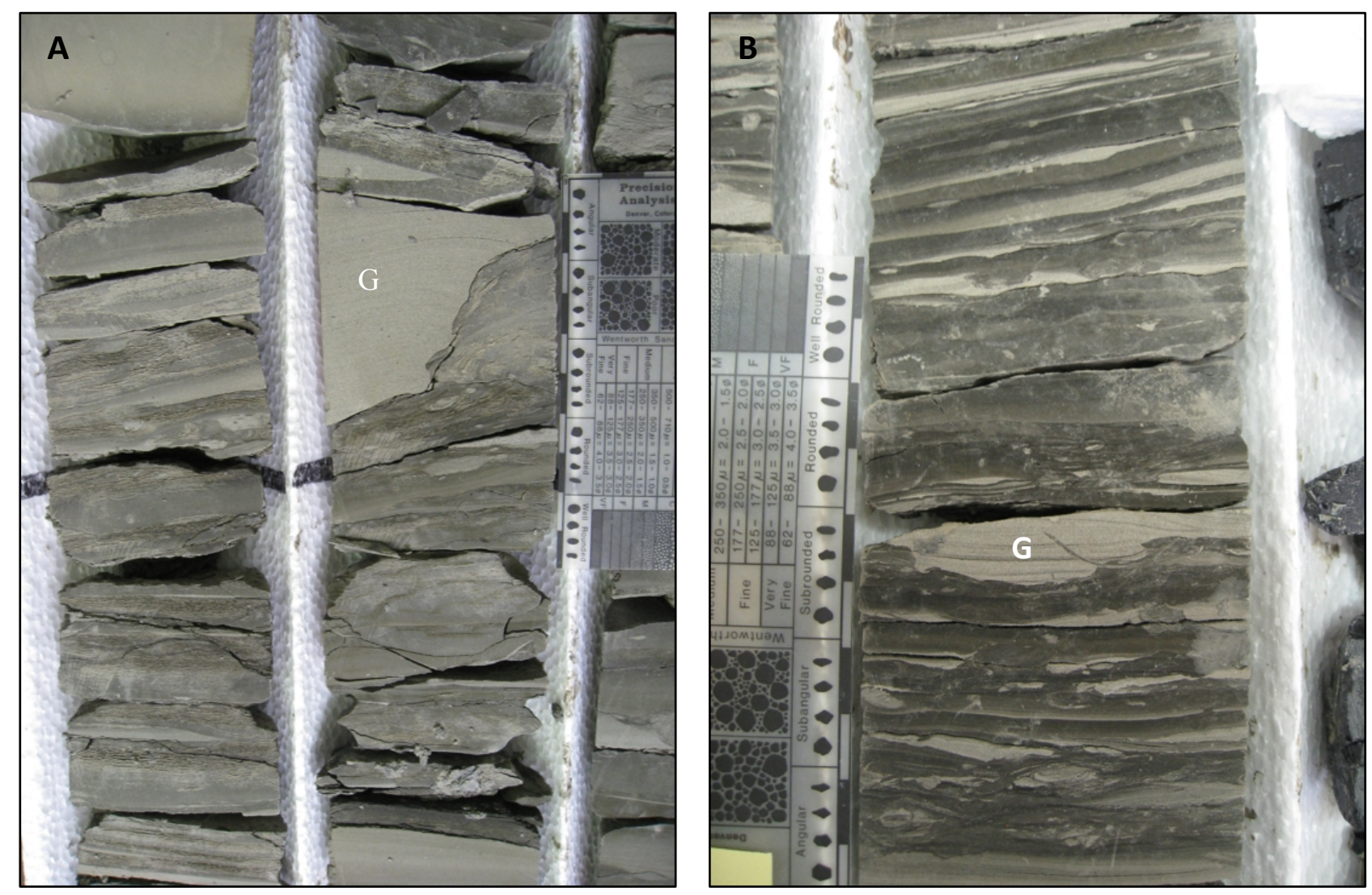

Figure 2-13. Photographs showing selected features in the heterolithic sandstone and mudstone facies (SFh). Scale on edge of grain-size comparator in all photos is marked in centimeters. A. Thinly interbedded sandstone and mudstone of facies SFh near a depth of 1,579 ft (black line on core tray at left). Note the relatively large gutter cast (white $\mathrm{G}$ ), indicating that at least some of the flows that transported sand to this location were highly erosive. B. Thinly laminated sandstone and mudstone of facies SFh at a depth of approximately $1,455.5 \mathrm{ft}$. Note the small gutter cast (white G). C. Interlaminated sandstone and mudstone of facies SFh at a depth of $1,454.5 \mathrm{ft}$. Note subtle normal grading in some sandstone laminae (white triangle).

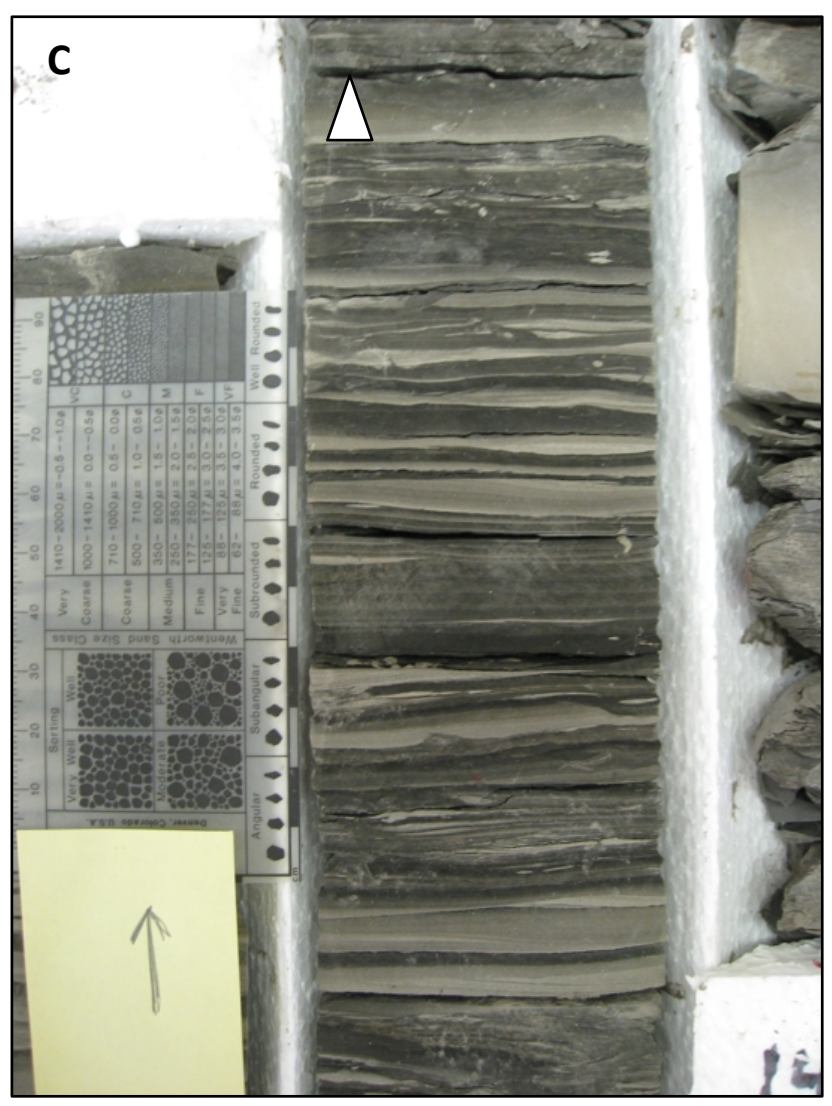



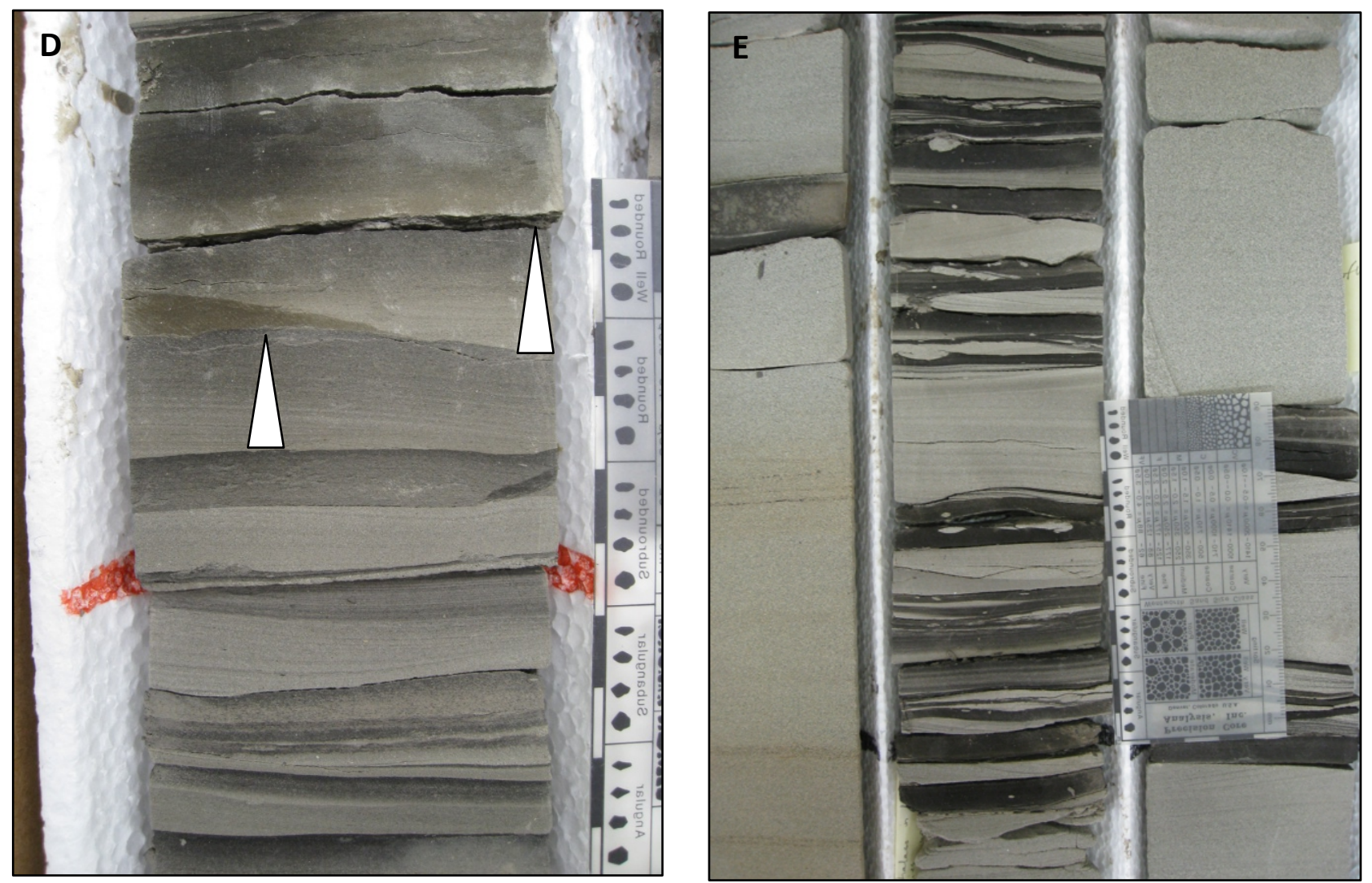

Figure 2-13 (continued). Photographs showing selected features in the heterolithic sandstone and mudstone facies (SFh). Scale on edge of grain-size comparator in all photos is marked in centimeters. D. Normally graded sandstone (white triangles) and minor interbedded mudstone of facies SFh at a depth of $607 \mathrm{ft}$ (red line in core tray). E. Interbedded sandstone and mudstone of facies SFh at a depth of 1,476 ft (black line in center core tray). Note the relatively thick sandstone beds in this example of facies SFh (middle core).

transported sand to the depositional site (figs. 13A-B). Definition of this facies is more arbitrary than others in the core: it is the presence of thinly interlaminated sandstone and mudstone in roughly equal abundance forming a repetitive succession that distinguishes facies SFh from other facies. Bioturbation ranges from II 1 to II 3. Skolithos is the only genera recognized.

\section{Interpretation}

Facies SFh records deposition under fluctuating energy conditions. Sand and coarse silt were transported to the depositional site as bedload and suspended load by turbulent flows associated with relatively-high-energy events. Graded sandstone beds indicate deposition from waning density currents-possibly hyperpycnal flows-though the classic signature of such deposits has not been recognized in this core (Mulder and others, 2003, their fig. 2-9). Interbedded mudstones record deposition from suspension during the waning phase of high-energy events and suspension settling during the intervening lower-energy periods. Given only this one core it is difficult to be more specific in interpreting this facies. Periodic fluctuation in flow strength and direction due to tides is a reasonable interpretation (Thomas and others, 1987; Nio and Yang,
1991) as is episodic overbank flooding and deposition on subaqueous levees (Coleman and others, 1964; Elliot, 1974).

\section{FACIES ASSOCIATIONS AND DEPOSITIONAL SETTING}

The 12 facies outlined in the previous section combine to define six facies associations that, collectively, record deposition in lower delta plain to upper delta plain (upper $190 \mathrm{ft}$ of core) settings (fig. 2-19). These correspond closely to the depositional record of several subenvironments on the delta plain of the Mississippi River (Fisk and others, 1954; Coleman and Gagliano, 1965; Bhattacharya, 2006), including interdistributary bays, distributary channels, crevasse channels, minor mouth bars/crevasse deltas, and channel levees. Like most delta plain successions, facies associations comprising the Wainwright core stack to form a complex succession (compare Fisk and others, 1954; Coleman and others, 1964; Fisher and others, 1969; Horn and others, 1978; Bhattacharya and Walker, 1991). Unequivocal interpretation of the depositional environment is difficult for many segments of the core due to the one-dimensional view afforded by a single core through a 
complex suite of deltaic subenvironments.

Trace fossils and bioturbation fabrics provide valuable information that helps in constraining environmental interpretations of the Wainwright core. Lower delta plain settings in high-constructional, river-dominated deltas are characterized by low-lying marsh and swamp lands interrupted by lakes and interdistributary bays (Fisher and others, 1969). With the constant input of fresh water from riverine sources, water over most of the lower delta plain is fresh to brackish (Coleman and others, 1964). Bioturbation is common in the lower $1,300 \mathrm{ft}$ of the Wainwright core. Most of the identifiable trace fossils are common components in open marine siliciclastic shelf, shoreface, and deltaic successions and include traces assignable to either the Cruziana or Skolithos ichnofacies assemblages (MacEachern and others, 2007a; Pemberton and others, 1992). Trace fossils recognized include Diplocraterion(?), Skolithos, Rhizocorallium, Rosellia(?), Teichichnus, Thalassinoides, Paleophycos, Phycosiphon (and/or Helminthopsis), and Planolites. These genera, taken as an assemblage, resemble high-diversity assemblages in settings characterized by normal marine salinities (Pemberton and others, 1992; MacEachern and others, 2007a). Despite their recognition in the Wainwright core, most bioturbated beds include only a few genera (some only one) and, as a result, are interpreted as low-diversity assemblages that record ecological stress (Pemberton and Wightman, 1992; MacEachern and others, 2007b). The beds with many genera probably record short-lived perturbation of "normal" conditions for the depositional sites that allowed a diverse infaunal assemblage to persist for a brief period.

Bioturbation ranges from absent (II 1), to one or two recognizable traces in an otherwise undisturbed bed (II 2) interstratified with beds that appear undisturbed, to single beds and successions (multiple beds) that are moderately bioturbated (II 3-4). The trace fossil assemblages and their distribution demonstrate a persistent marine influence during deposition of the lower $1,300 \mathrm{ft}$ of the cored succession and, at times, water may have approached normal marine salinities.

Facies associations are briefly described and interpreted in this section, followed by a depositional model that integrates features recognized in the Wainwright \#1 core.

\section{INTERDISTRIBUTARY BAY}

The interdistributary bay association is composed of several facies including massive mudstone (Fm), laminated mudstone $(\mathrm{Fl})$, laminated fine-grained sandstone (Slf), ripple cross-laminated fine-grained sandstone (Sr), massive sandstone $(\mathrm{Sm})$, minor burrow-mottled sandstone $(\mathrm{Sb})$, minor convolute-bedded sandstone $(\mathrm{Scb})$, heterolithic sandstone and mudstone (SFh), carbonaceous mudstone ( $\mathrm{Fc}$ ), and coal (sheet 2-1). Mudstone facies are most abundant and interbedding of the various facies forms a complex succession (fig. 2-14). This complexity is reflected in the gamma-ray profile, which is typically highly serrated (sheet 2-1). Many sandstone and mudstone beds are bioturbated (facies Sb and Fm?) with ichnofabric indices ranging from II 2 to II 4 . The interdistributary bay association envelops most of the remaining associations.

The suite of facies outlined above records deposition in low-energy, shallow-water settings between deltaic distributary channels. The facies association is similar to modern interdistributary bay deposits described from the lower delta plain of the Mississippi River in classic works by Coleman and others (1964) and Coleman and Gagliano (1965), and closely resembles deposits recognized in many ancient deltaic successions (Carboniferous of southwestern England by Collinson, 1968; Elliott, 1976; Carboniferous of eastern North America by Horn and others, 1978; Cenomanian of northwestern Alberta by Bhattacharya and Walker, 1991; Late Cretaceous of Utah by Ryer and Anderson, 2002). Interdistributary bay deposits have been recognized elsewhere in the Nanushuk Formation by Huffman and others $(1985,1988)$, LePain and Kirkham (2001), and LePain and others $(2008 ; 2009)$.

The interdistributary bay setting was interrupted episodically by incursions of coarser-grained sediment as flood waters in nearby channels overtopped poorly developed levees and transported fine-grained sand in suspension and as bedload in sheet flows depositing facies Slf, Sr, Sm, and Scb (fig. 2-14). Mudstones containing a few thin sandstone interbeds record splay deposition in settings distal to channels, whereas many thin to thick sandstone beds and amalgamated sandstone beds indicate deposition proximal to active channels. Waveripple cross-lamination in some sand beds indicates local reworking by short-period waves (shallow water). Trace fossils recognized in this association define a low-diversity assemblage consistent with deposition in a brackish water setting (Pemberton and Wightman, 1992). Syneresis cracks recognized at a depth of $1,532 \mathrm{ft}$ indicate fluctuating salinity, which is consistent with deposition in an interdistributary bay setting characterized by frequent changes in the relative supply of freshwater and seawater.

The scarcity of storm-wave-generated structures (possible hummocky cross-stratification only at approximately $589 \mathrm{ft}$, between 513 and $514 \mathrm{ft}$, between 1,412 and $1,413 \mathrm{ft}$, and at 1,475.5 ft; sheet 2-1; figs. 2-9E and 14) is consistent with deposition in low-energy bays protected from open marine conditions. Coal and carbonaceous mudstone are relatively common and demonstrate the presence of peat swamps along the perimeter of many bays in locations removed from sources of coarse-grained sediment (Fisher and others, 1969; Horn and others, 1978; Bhattacharya and Walker, 1991).

The thick interdistributary bay-fill succession between 1,242 and $1,495 \mathrm{ft}$ is a good example of this association (sheet 2-1). This interval includes thinly laminated mudstone that accumulated in a quiet-water setting distal to active channels-the thin laminations indicating little, if any, disturbance by burrowing organisms after deposition (sheet 2-1; fig. 2-14; 1,375.5-1,396 ft). This interval also includes a succession of interbedded mudstone (largely 

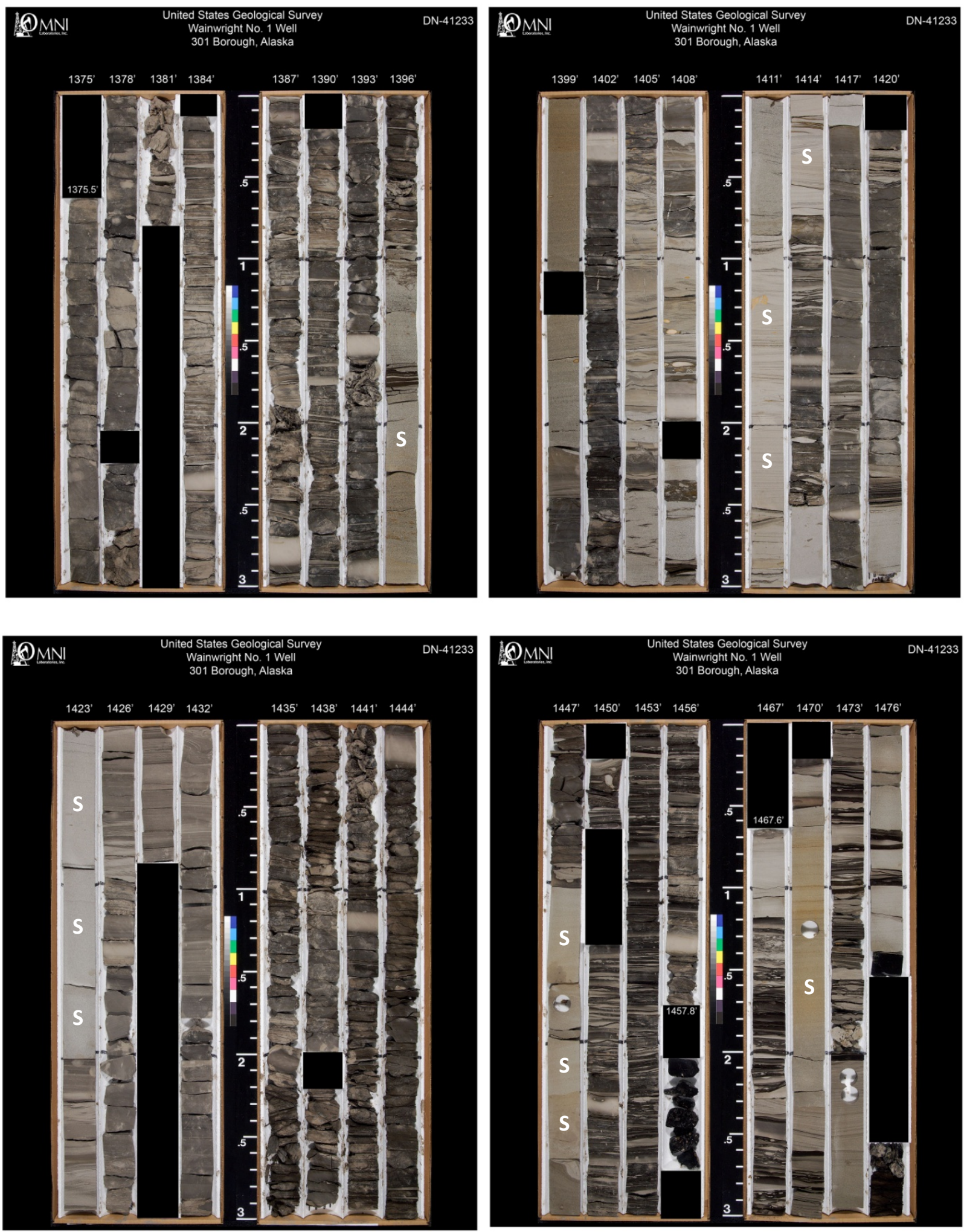

Figure 2-14. Core photos, showing the typical expression of the interdistributary bay association. The base of the succession shown is at a depth of 1,479 ft, corresponding to the lower right corner of the lower right photo; the top of the succession shown is at a depth of 1,375 ft, corresponding to the upper left corner of the upper left photo. The interdistributary bay succession consists of dark brown to dark gray mudstone with numerous thin sandstone laminae and several thicker sandstone beds interpreted as tabular crevasse-splay deposits. Sandstones are light tan to light reddish tan; selected beds are marked with a white $\mathrm{S}$. The black rectangles correspond to coals that were removed for laboratory analysis. 
$\mathrm{Fl}$ with minor $\mathrm{Fm}$ and $\mathrm{Fc}$ ) and sandstone (Slf, Sr, and Scb) interpreted as splay sand sheets (fig. 2-14;1,396-1,476 ft).

\section{CHANNEL}

The channel association consists of cross-bedded sandstone (Sx), fine- to medium-grained, plane-parallel laminated sandstone (Slm), massive sandstone (Sm), and ripple cross-laminated sandstone facies (Sr; sheet 2-1). The association has sharp bounding contacts with mudstones of the interdistributary bay association and sandy siltstones and thin sandstones of the levee association. The lower contact is erosive and the association is characterized by a fining-upward grain-size motif and barrel- to bell-shaped gamma-ray profile. Fine- to medium-grained cross-bedded sandstone (Sx) and plane-parallel laminated sandstone (Slm) comprise the lower and middle portion of most channel fills; these facies grade upsection to fine-grained, ripple cross-laminated sandstone. Internal erosion surfaces are common and are often overlain by siderite clast or mudstone chip lags.

A thick succession from $1,060.5$ to $1,157.7 \mathrm{ft}$ includes at least two fining-upward successions interpreted as two amalgamated channel fills (distributary channels; sheet 2-1; fig. 2-15). The lowest is capped by a siderite band a few inches thick (at 1,095.6 ft), whereas the uppermost foot or so of the upper fining-upward succession includes rhizoliths and is overlain by carbonaceous mudstone of the interdistributary bay association (fig. 2-15, above 1,060.5 ft). Collectively, the fine-grained, ripple cross-laminated sand, siderite bands, and rhizoliths (only in the uppermost succession) capping these two channel-fill successions indicate waning flow and channel abandonment. The upper fining-upward succession either represents rejuvenation of the same channel or reoccupation of the same location by a different channel. Repetitive mudstone drapes on sandstone between 1,153.3 and 1,154.5 ft, and interbedded, fine-grained, ripple cross-laminated sandstone (facies $\mathrm{Sr}$ ) and plane-parallellaminated sandstone (facies Slm and Slf), both including mud drapes, between 1,100 and $1,102.5 \mathrm{ft}$, suggest a tidal influence (fig. 2-15). Rhizoliths capping the uppermost succession $(1,060-1,061 \mathrm{ft})$ indicate the depositional surface was either emergent or in shallow enough water that marsh-type plants were able to grow.

The facies composition and thickness of channel fills recognized in the Wainwright core are comparable to channel deposits recognized in other ancient deltaic successions (Dunvegan Formation of Bhattacharya and Walker, 1991; Ferron Sandstone of Ryer and Anderson, 2002; Wilcox Group of Galloway, 1968), and in outcrops of the Nanushuk Formation (McCarthy, 2003; LePain and others, 2009). Subsurface data suggest the amalgamated channels from $1,060.5$ to $1,157.7 \mathrm{ft}$ and 619.3 to $667 \mathrm{ft}$ are part of channel belts that have regional extent in the depositional dip direction (northeast to the east; Decker, 2016 [this volume]). If the $97-\mathrm{ft}$-thick succession shown in fig. 2-15 and discussed in the previous paragraph is the depositional record of a single channel, it was comparable in size (at least scour depth) to the modern Mississippi River along its lower reaches in Louisiana (see channel cross-sections in Fisk, 1947).

\section{CREVASSE CHANNEL}

The crevasse channel association consists largely of ripple cross-laminated sandstone ( $\mathrm{Sr}$ ), and minor finegrained, plane-parallel laminated sandstone (slf), massive sandstone $(\mathrm{Sm})$, and convolute bedded sandstone ( $\mathrm{Scb}$ ). This association has a sharp lower contact with mudstone, can have a sharp or gradational upper contact with mudstone, and has a fining-upward grain-size motif and blocky- to bell-shaped gamma-ray profile (sheet 2-1; fig. 2-16, base; fig. 2-17, 587.5 to 593.3 feet). The crevasse channel association is differentiated from the distributary channel association by sediment grain size and total thickness-the former being thinner and consisting of finer-grained sand. With these criteria, it is still possible that some occurrences of the distributary channel association have been misidentified as crevasse channel fills. Further blurring this distinction is that large crevasse channels can evolve into major distributaries under the right conditions (Elliot, 1974).

The crevasse channel association represents the fill of relatively long-lived channels that cut through distributary channel levees. Channels were cut during major flood events and acted as conduits for transporting relatively coarse-grained sediment to quiet water settings in adjacent interdistributary bays (Coleman and others, 1964; Elliott, 1974). The fining-upward grain-size trends recognized in some crevasse channel fills record waning flow and gradual abandonment. Bioturbation, if present, is limited to the upper part of crevasse channel fills, indicating that flow velocities were too strong and/ or freshwater from the feeder channels made conditions inhospitable for burrowing organisms when channels were active (fig. 2-16). Burrowing organisms (or colonizing plants) were able to colonize the substrate only after channels were abandoned and sedimentation rates were greatly reduced (Elliott, 1976).

\section{MINOR MOUTH BAR/CREVASSE DELTA}

The minor mouth bar/crevasse delta association, referred to hereafter as the mouth bar association, consists of laminated mudstone $(\mathrm{Fl})$, massive mudstone $(\mathrm{Fm})$, ripple cross-laminated sandstone ( $\mathrm{Sr})$, fine-grained plane-parallel laminated sandstone (Slf), convolutebedded sandstone ( $\mathrm{Scb})$, and heterolithic sandstone and mudstone (SFh; sheet 2-1). The mouth bar association gradationally overlies interdistributary bay deposits and is overlain abruptly by either crevasse channel-fill deposits or additional interdistributary bay deposits. A prominent coarsening-upward grain-size trend characterizes this association and examples typically grade upward from mudstone or interbedded mudstone and sandstone near the base to dominantly sandstone near the top (sheet 2-1; 

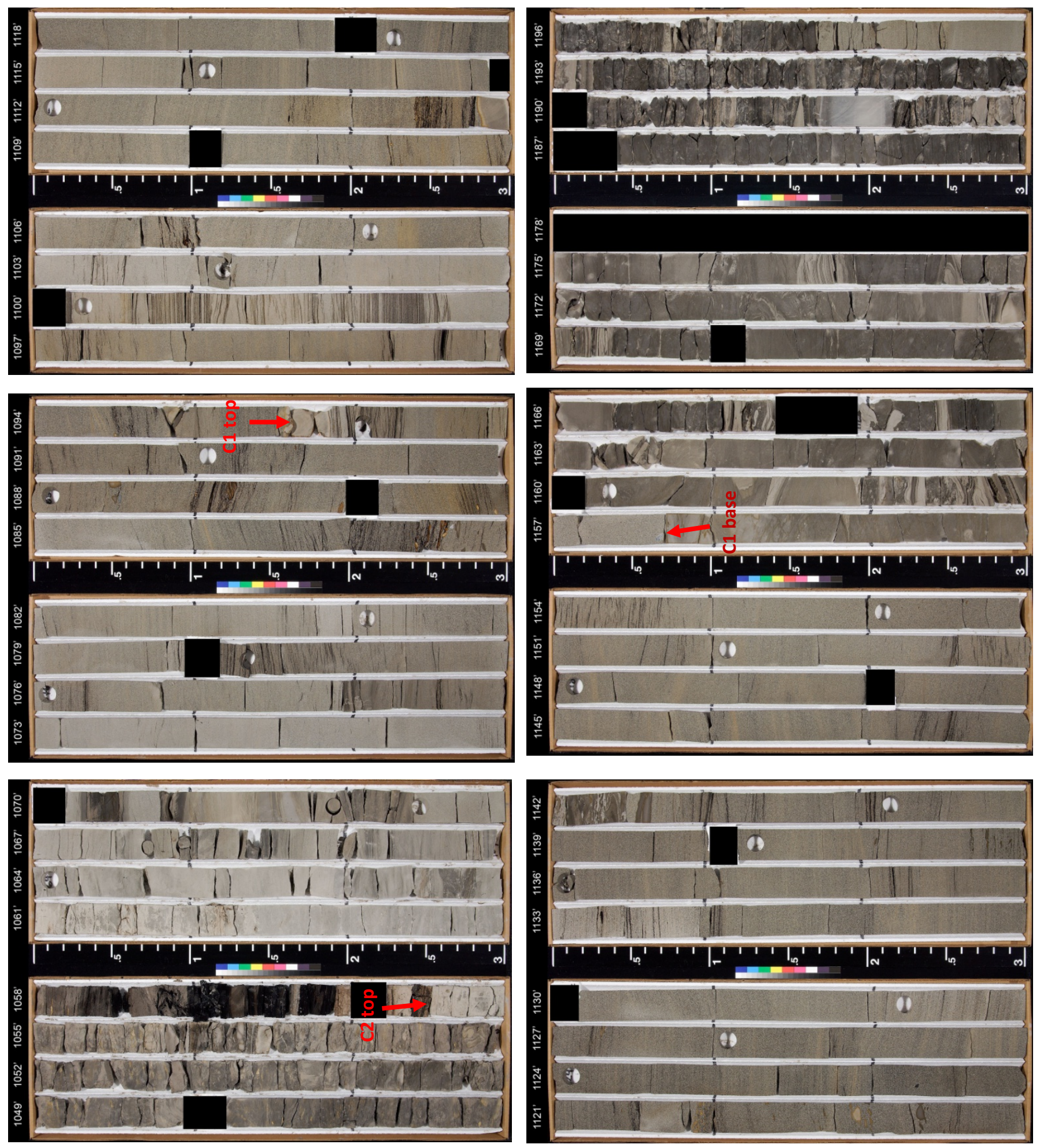

v่⿱亠凶禸㔾

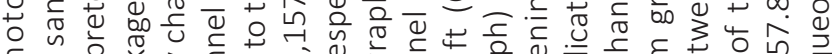

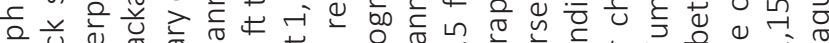

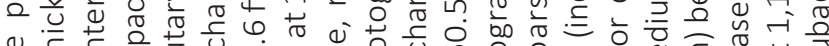

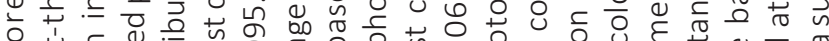

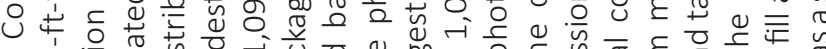

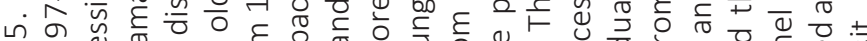

ᄀr

$\sim$ no

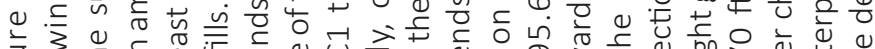

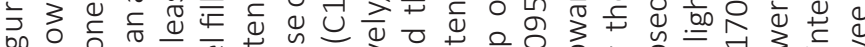

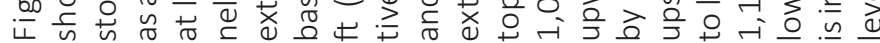


fig. 2-17; approximately 593.3 to $601 \mathrm{ft}$ ). The association records gradual progradation of mouth bars into quiet water interdistributary bay settings from the downstream ends of crevasse channels (Fisk and others, 1954; Coleman and others, 1964; Elliot, 1974).

The vertical succession through this association closely resembles mouth bar deposits recognized in modern interdistributary bay successions of the Mississippi River (Fisk and others, 1954; Coleman and others, 1964; Coleman and Gagliano, 1965; Elliott, 1974) and in ancient deltaic successions (Elliott, 1976; Horn and others, 1978; Bhattacharya and Walker, 1991), including the Nanushuk Formation (LePain and Kirkham, 2001; McCarthy, 2003; LePain and others, 2009). Examples that include mudstone at their base and culminate in amalgamated sandstone beds record a complete progression from distal mouth bar to crevasse channel deposits (fig. 2-17; 587.5 to $593.3 \mathrm{ft}$, interpreted as crevasse channel fill).
Most examples of this association in the Wainwright core lack wave-ripple cross-lamination, a structure that is commonly recognized in mouth bar deposits from other deltaic successions. The absence of wave-formed structures suggests deposition in low-energy bay settings below fair-weather wave base. Fair-weather wave base in open marine settings lies between 16 and $50 \mathrm{ft}$ (Walker, 1984) and is likely to occur at much shallower depths in protected bays such that mouth bar deposits could easily escape reworking by waves if the depositional surface did not build to within a few feet of the water surface. Gradual subsidence from compaction of underlying muds further ensured these mouth bar sands escaped wave reworking.

\section{CHANNEL LEVEE}

The channel levee association consists of laminated and massive mudstone (facies $\mathrm{Fl}$ and $\mathrm{Fm}$ ) and convolute bedded sandstone (Scb; sheet 2-1). Soft-sediment deformed beds,

Figure 2-16. Core photo, showing a finingupward succession between 1,001.4 and $1,021.8 \mathrm{ft}$, interpreted as the fill of a crevasse channel. Note the sharp contact with underlying mudstones of the interdistributary bay association (white arrow at 1,021.8 $\mathrm{ft}$ ) and the fining-upward grain-size motif indicated by the gradually increasing mud content in channel fill (gradually increasing number of dark-colored beds toward the top of the package, from approximately $1,001.4$ to 1,015.6 ft). The contact with overlying mudstones is sharp (white arrow at $1,001.4 \mathrm{ft}$ ). The fining-upward motif records gradual abandonment of the crevasse channel.

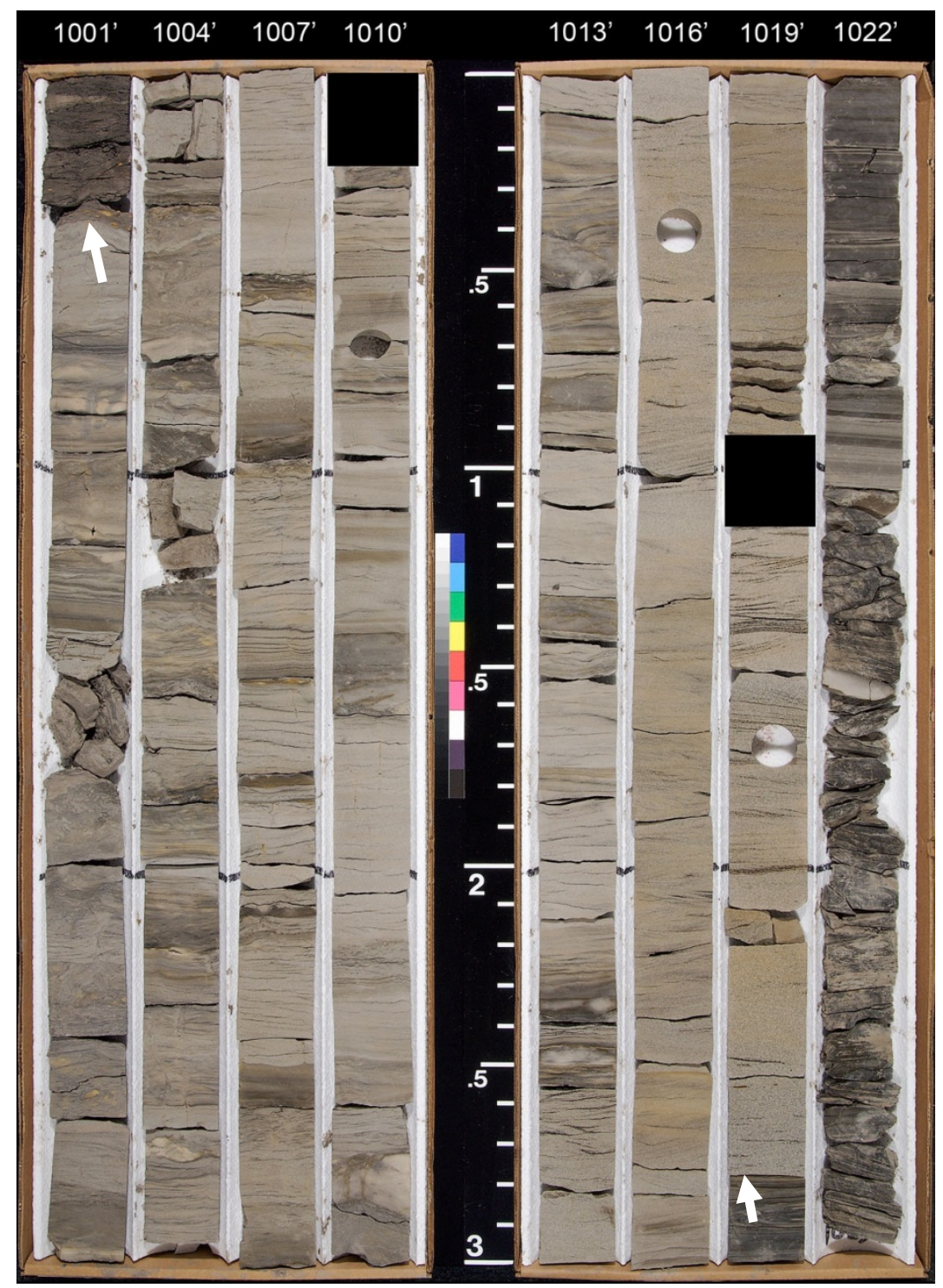


bioturbation textures, and in-place siderite(?) concretions are characteristic of this association. The basal contact with underlying associations (most commonly interdistributary bay) is gradational (sheet $2-1$; fig. $2-15 ; \sim 1,175$ to $1,193 \mathrm{ft}$ recording a transition from bayfill to distal levee), whereas the upper contact is typically sharp (fig. 2-15; $1,157.7 \mathrm{ft}$ ). The association is characterized by a subtle to prominent coarsening-upward grain-size motif. Both the channel levee and distributary mouth bar associations are characterized by coarsening-upward grain-size motifs and include similar facies. Given these similarities and limitations imposed by a single core, interpretation as channel levee deposits and our ability to clearly distinguish them from mouth bar deposits is questionable. Channel levee deposits have been recognized in the Nanushuk in outcrop (LePain and Kirkham, 2001; McCarthy, 2003; LePain and others, 2009).

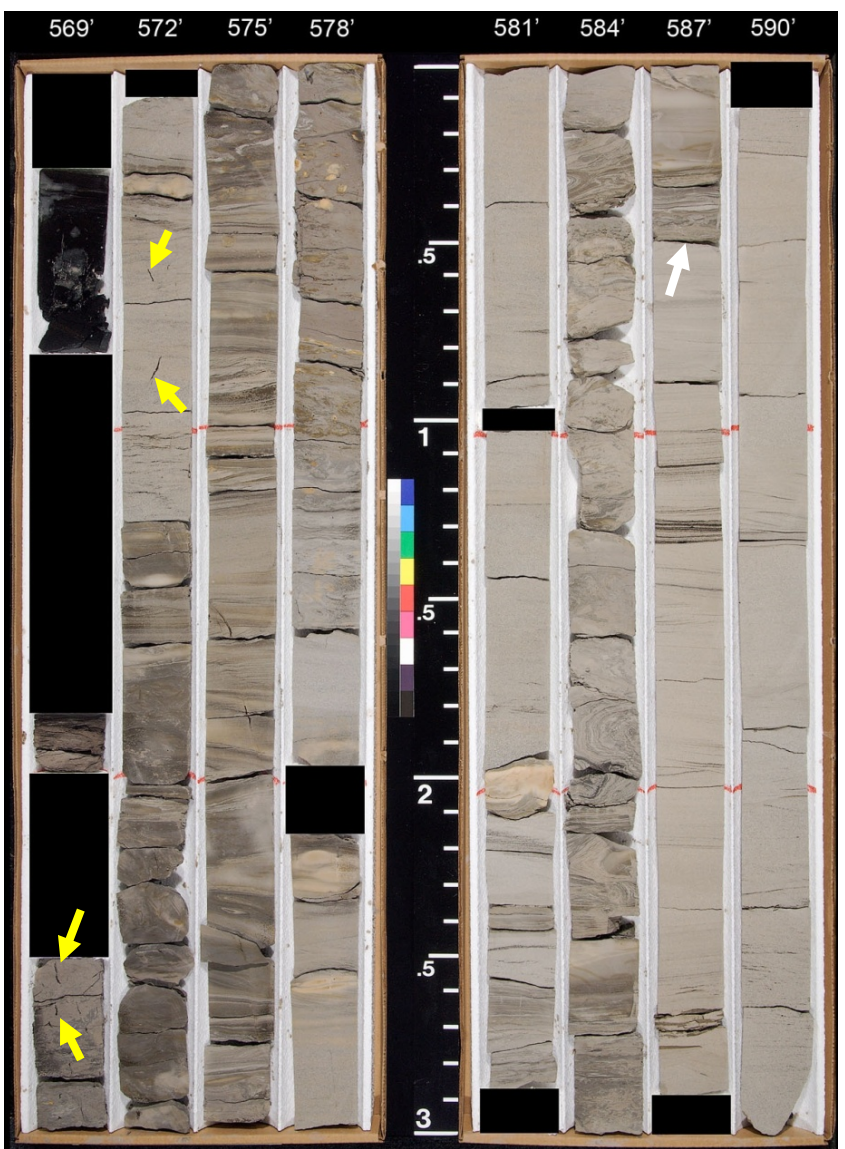

\section{ALLUVIAL FLOOD BASIN}

The alluvial flood basin association consists of laminated mudstone ( $\mathrm{Fl})$, massive mudstone $(\mathrm{Fm})$, carbonaceous mudstone $(\mathrm{Fc})$, and coal (C), with interbedded ripple cross-laminated sandstone (Sr), heterolithic sandstone and mudstone (SFh), and minor convolute-bedded sandstone (Scb; sheet 2-1). Figure 2-18 shows core from a depth of 123 to $226 \mathrm{ft}$ and represents a typical example of this association in the Wainwright well. The upper $104 \mathrm{ft}$ of core (not shown in fig. 2-18) commonly appears brecciated or disrupted, which may have resulted from permafrost or pedogenic processes. Scattered rhizoliths and possible soil peds suggest the presence of paleosols.

This association is interpreted as the deposits of a poorly drained alluvial flood basin. The absence of marine trace fossils distinguishes this association from the interdistributary bay association and provides the basis for differentiating lower delta plain deposits from upper delta plain deposits (Fisk and others, 1954; Bhattacharya,

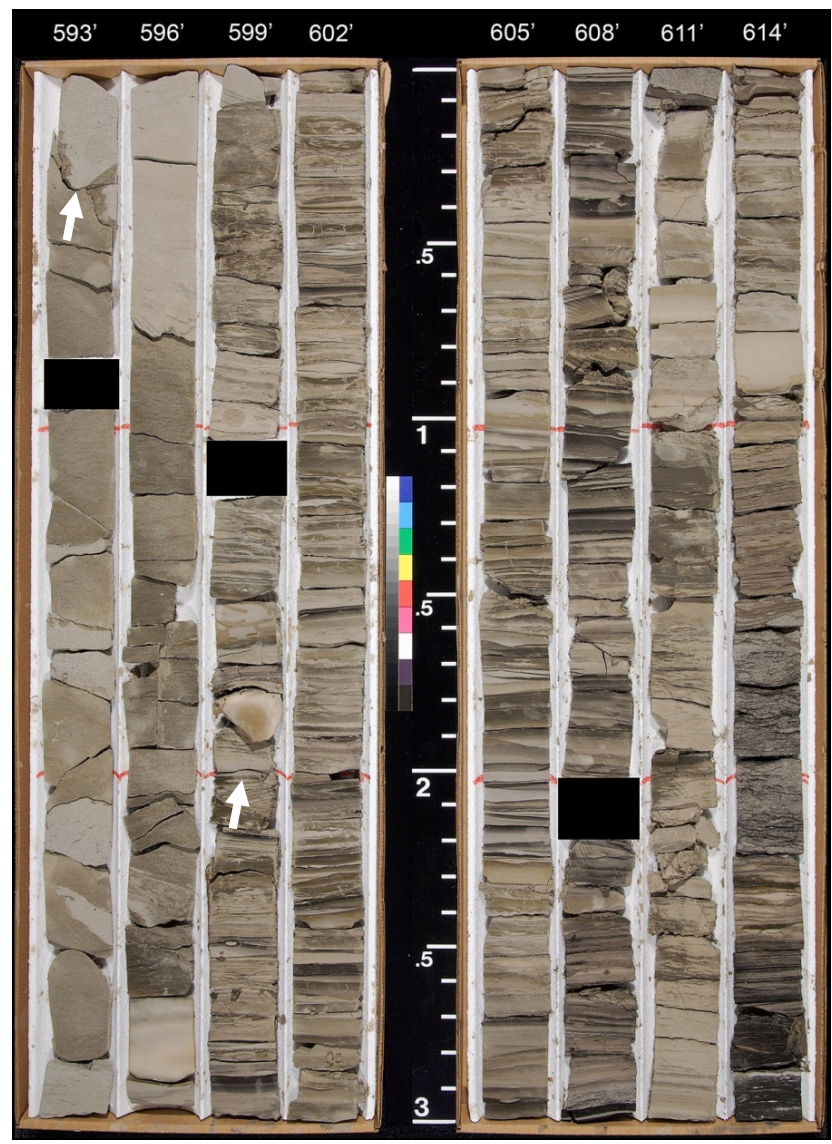

Figure 2-17. Core photo, showing prominent coarsening-upward succession (approximately 593.3 to $601 \mathrm{ft}$; white arrows) interpreted as the deposits of a crevasse delta. The erosion surface separating light-colored clean sandstone from darkercolored muddy sandstone to sandy siltstone at $593.3 \mathrm{ft}$ (white arrow) is interpreted as a scour surface marking the base of a small crevasse channel that cut into crevasse delta mouth bar deposits. The mudstone and muddy sandstone above the upper white arrow (587.5 ft) may record gradual abandonment of the crevasse channel. Sandstones above $584.2 \mathrm{ft}$ are probably splay sandstone sheets. Note rhizoliths in sandstone at $572.6 \mathrm{ft}, 572.9 \mathrm{ft}$, and in mudstone at 571.6 and $571.7 \mathrm{ft}$ (yellow arrows). 

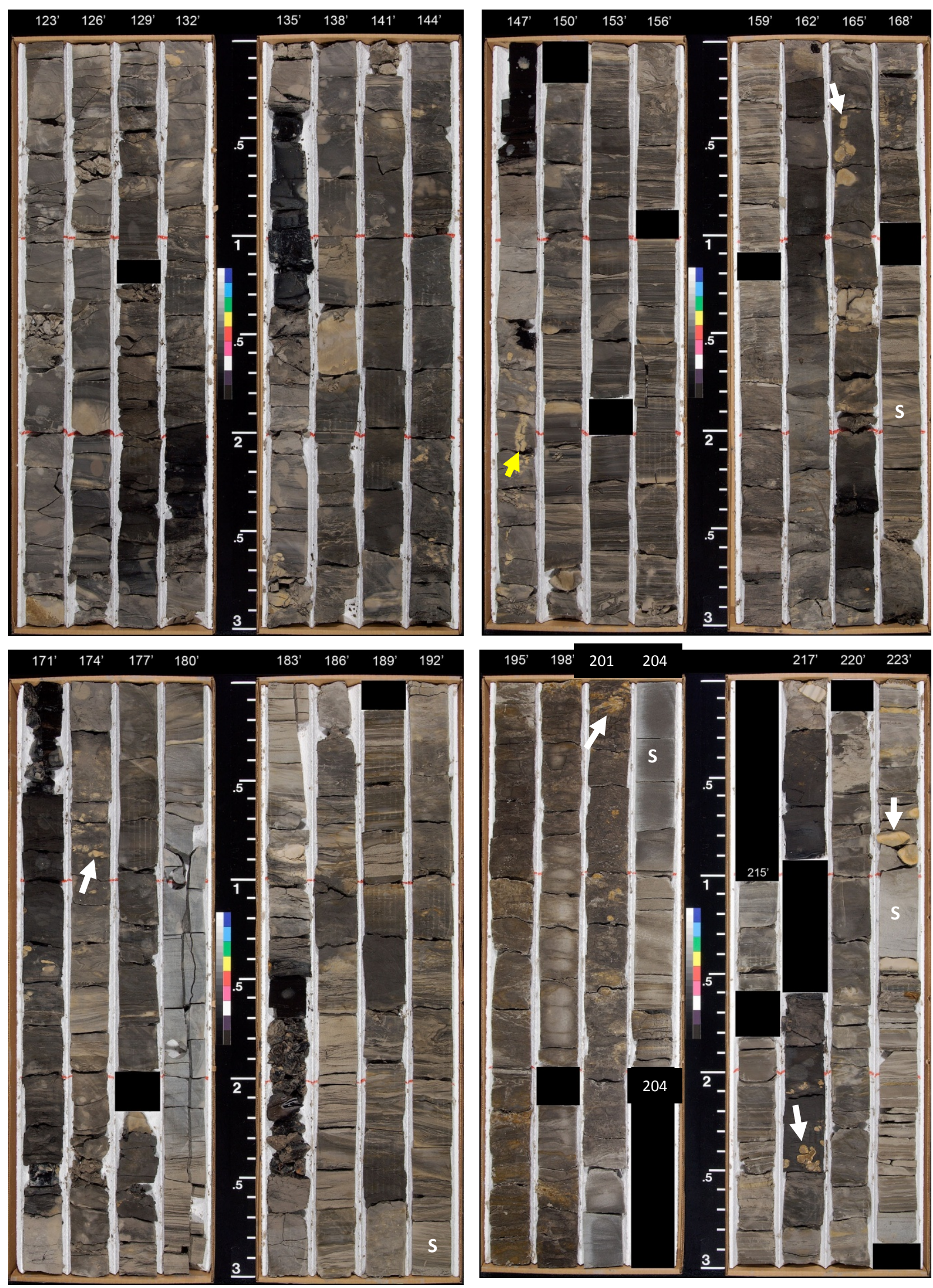

Figure 2-18. Core photos, showing a thick mudstone succession from 123 to $226 \mathrm{ft}$ interpreted as alluvial flood basin deposits (upper delta plain). The lighter-colored beds are sandstones that were deposited as tabular splays (white S). Note the sideritized rhizolith(?) at $149 \mathrm{ft}$ (yellow arrow) and the siderite nodules throughout (selected nodules shown with white arrows). 
2006). Alluvial floodbasin deposits have been recognized in outcrops of the Nanushuk Formation south of Umiat (McCarthy, 2003; LePain and others, 2009).

\section{DEPOSITIONAL MODEL}

The suite of facies and facies associations recognized in the Wainwright \#1 well is consistent with deposition in a lower delta plain setting characterized by interdistributary bays, major channels, and associated subenvironments (levees, crevasse channels, etc.; fig. 2-19). The persistent presence of a moderate to low diversity suite of marine trace fossils throughout much of the lower 1,300+ $\mathrm{ft}$ of core suggests that interdistributary bays were routinely characterized by brackish water and, for brief periods, may have had normal marine salinities. The suite of facies and the lack of obvious trace fossils above a depth of $265 \mathrm{ft}$ is consistent with deposition in a poorly drained alluvial (upper delta) plain setting. Subsurface and core data suggest the thick channel deposits between 1,060.5 and 1,157.7 ft and between 619.3 and $667 \mathrm{ft}$ represent attractive analogs for potential reservoirs in topsets up depositional dip (west) from the ultimate Nanushuk shelf edge on the central North Slope (see Houseknecht and others, 2008, their figs. 1 and 3). The absence of significant thicknesses of sandstones with abundant wave-generated structures, including hummocky cross-stratification, is consistent with deposition in a river-dominated deltaic setting (Bhattacharya, 2006). This is also consistent with previous interpretations of Nanushuk deltas west of the Meade arch as river dominated (Ahlbrandt and others, 1979; Huffman and others, 1985).

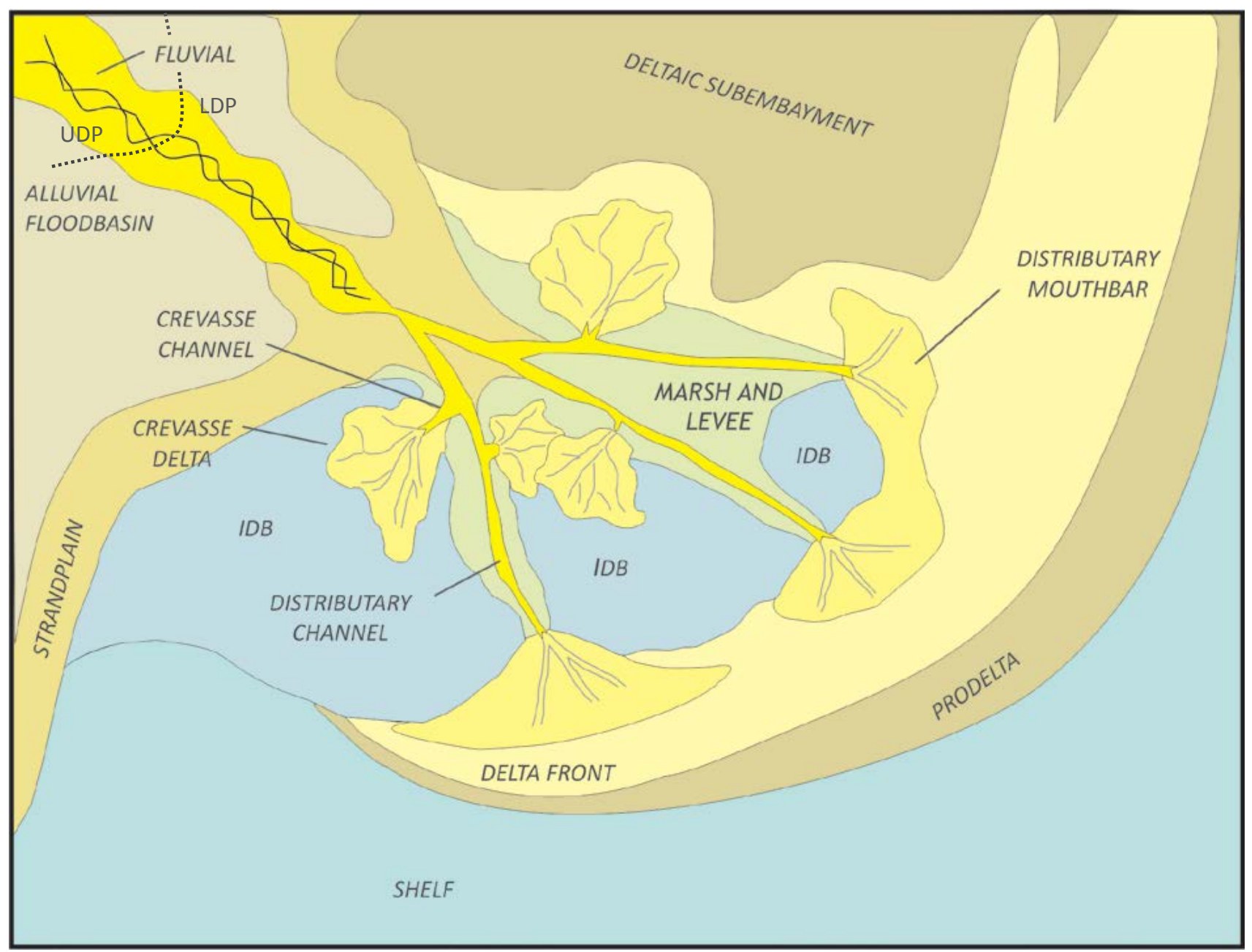

Figure 2-19. Generalized drawing showing a delta lobe and its subenvironments (modified from LePain and others, 2009). The progression of environments recorded in the core, from base to top, defines a progradational succession starting with prodelta or interdistributary bay mudstones and thin-bedded sandstone with trace fossils suggestive of reduced salinity conditions, and ending in an alluvial flood basin package lacking marine indicators. The interdistributary bayfill succession in the lower 85 percent of the core is punctuated by numerous splay sandstones, crevasse channel fills, distributary channel fills, and at least one levee succession. IDB = interdistributary bay; LDP = lower delta plain; UDP = upper delta plain. 


\section{CONCLUSIONS}

Our facies analysis of the Wainwright \#1 core has identified 12 lithofacies, which combine to define six facies associations. Facies associations include most of the subenvironments associated with river-dominated deltas, including interdistributary bay, distributary channel, channel levee, crevasse channel and delta, and splay sand sheets. The interdistributary bay association dominates the cored interval and envelops all other associations in the lower $1,340 \mathrm{ft}$ of core; the alluvial flood basin association dominates the upper $265 \mathrm{ft}$ of core. Trace fossils are common and locally abundant in the lower $1,340 \mathrm{ft}$ of the cored succession, but have not been identified in the upper $265 \mathrm{ft}$. Trace fossils include genera belonging to both the Cruziana and Skolithos ichnofacies. The massive mudstone facies $(\mathrm{Sm})$ commonly appears burrow mottled, while most sandstone beds having trace fossils appear only lightly bioturbated. These beds usually only include traces belonging to a few genera, defining low- to moderate-diversity assemblages. A few sandstone beds are moderately to highly bioturbated. These beds include high-diversity assemblages consisting of several genera typically found in open marine settings. The distribution of facies associations and trace fossil assemblages allow distinction of lower and upper delta plain settings. The lower $1,340 \mathrm{ft}$ of core records a persistent marine influence (mostly brackish water, with only a few beds recording normal marine salinity) and represents deposition in a lower delta plain setting. Marine trace fossils are absent in the upper part of the cored succession, which comprises alluvial flood basin, mire, and splay sand associations deposited in an upper delta plain setting removed from marine influence. The suite of facies associations documented in the Wainwright \#1 core is consistent with deposition in a river-dominated deltaic setting.

Core from the Wainwright \#1 well provides important information on the reservoir potential of the Nanushuk Formation. The thick channel complex between 1,065.5 and $1,157.7 \mathrm{ft}$ appears to have significant regional extent (Decker and LePain, 2016 [this volume]) and represents an attractive reservoir target. This channel complex is encased in mudstones of the interdistributary bay association, which would serve as an effective stratigraphic trap for hydrocarbons. Thinner channel deposits have also been recognized in the core between 619 and $667 \mathrm{ft}$ that are also encased in a mudstone-dominated succession. Judging from this core and analog data from outcrops to the south and southeast (Huffman and others, 1985, 1988; LePain and others, 2008, 2009), it is reasonable to infer that stacked reservoirs could easily be present in the formation in the subsurface of the central North Slope. This conclusion is consistent with core from exploration wells in the central and eastern NPRA (LePain and Kirkham, 2001). See Helmold (2016 [this volume]) for information on the reservoir quality of the cored succession.

\section{ACKNOWLEDGMENTS}

We thank David Houseknecht and Ken Bird of the USGS for allowing access to the Wainwright core prior to shipping it from Anchorage to Denver, and for providing high-quality core photographs and wireline log data. In addition, we gratefully acknowledge the U.S. Geological Survey for paying to have the core slabbed. Art Clark managed drilling, coring, and wireline logging operations in Wainwright for the USGS and is responsible for field operations that resulted in excellent core recovery and quality. We thank Conoco-Phillips management for permission to use core layout space at the company's storage facility in Anchorage. We gratefully acknowledge Dede Schwarz, Dan Przywojski, and Mike McCracken of ConocoPhillips for their help laying out the core. We thank Marwan Wartes and Paul McCarthy for reviewing a draft of this report and offering many suggestions that helped improve our facies descriptions and clarify our interpretations.

\section{REFERENCES CITED}

Ahlbrandt, T.S., Huffman, A.C., Fox, J.E., and Pasternack, I., 1979, Depositional framework and reservoir quality studies of selected Nanushuk Group outcrops, North Slope, Alaska, in Ahlbrandt, T.S., ed., Preliminary geologic, petrologic, and paleontologic results of the study of Nanushuk Group rocks, North Slope, Alaska: U.S. Geological Survey Circular 794, p. 14-31.

Allen, J.R.L., 1984, Sedimentary structures, their character and physical basis (unabridged; one-volume edition)Developments in sedimentology, 30: Amsterdam, Netherlands, Elsevier, 663 p.

Ashley, G.M, 1990, Classification of large-scale subaqueous bedforms-A new look at an old problem: Journal of Sedimentary Petrology, v. 60, no. 1, p. 160-172.

Bhattacharya, J.P., 2006, Deltas, in Posamentier, H.W., and Walker, R.G., eds., Facies Models Revisited: SEPM Society for Sedimentary Geology, Special Publication 84, p. 237-292.

Bhattacharya, J.P., and Walker, R.G., 1991, River- and wave-dominated depositional systems of the Upper Cretaceous Dunvegan Formation, northwestern Alberta: Bulletin of Canadian Petroleum Geology, v. 39, no. 2, p. 165-191.

Bird, K.J., and Molenaar, C.M., 1992, The North Slope foreland basin, Alaska, in Macqueen, R.W., and Leckie, D.A., eds., Foreland basins and fold belts: AAPG Memoir 55, p. 363-393.

Clark, A.C., 2014, Coalbed natural gas exploration, drilling activities, and geologic test results, 2007-2010, Wainwright, Alaska: U.S. Geological Survey Open-File Report 2014-1004, 65 p. doi:10.3133/ofr20141004

Coleman, J.M., and Gagliano, S.M., 1965, Sedimentary structures, Mississippi River deltaic plain, in Middleton, G.V., ed., Primary sedimentary structures and 
their hydrodynamic interpretation: SEPM Special Publication 12, p. 133-148.

Coleman, J.M., Gagliano, S.M., and Webb, J.E., 1964, Minor sedimentary structures in a prograding distributary: Marine Geology, v. 1, no. 3, p. 240-258. doi:10.1016/0025-3227(64)90062-3

Collinson, J.D., 1968, The sedimentology of the Grindslow shales and Kinderscout grit-A deltaic complex in the Namurian of northern England: Journal of Sedimentary Petrology, v. 39, no. 1, p. 194-221. doi:10.1306/74D71C17-2B21-11D7-8648000102C1865D

Collinson, J.D., and Thompson, D.B., 1989, Sedimentary structures, 2nd edition: London, Unwin Hyman, $207 \mathrm{p}$.

Dalrymple, R.W., 1992, Tidal depositional systems, in Walker, R.G., and James, N.P., eds., Facies modelsResponse to sea level change: Geological Association of Canada, p. 195-218.

Decker, P.L., 2007, Brookian sequence stratigraphic correlations, Umiat Field to Milne Point Field, west-central North Slope, Alaska: Alaska Division of Geological \& Geophysical Surveys Preliminary Interpretive Report 2007-2, 19 p., 1 sheet. doi:10.14509/15758

Decker, P.L., and LePain, D.L., 2016 [this volume], Subsurface relationships of Albian-Cenomanian shallow marine to nonmarine topsets of the Nanushuk Formation, northwestern NPRA, northern Alaska, in LePain, D.L., ed., Stratigraphic and reservoir quality studies of continuous core from the Wainwright \#1 coalbed methane test well, Wainwright, Alaska: Alaska Division of Geological \& Geophysical Surveys Report of Investigation 2016-3, 56 p. doi:10.14509/29655

de Raaf, J.F.M., Boersma, J.R., and Van Gelder, A., 1977, Wave-generated structures and sequences from a shallow marine succession, Lower Carboniferous, County Cork, Ireland: Sedimentology, v. 24, no. 4, p. 451-483. doi:10.1111/j.1365-3091.1977.tb00134.x

Droser, M.L., and Bottjer, D.J., 1986, A semiquantitative field classification of ichnofabric: Journal of Sedimentary Petrology, v. 56, no. 4, p. 558-559.

Elliot, T., 1974, Interdistributary bay sequences and their genesis: Sedimentology, v. 21, no. 4, p. 611-622. doi:10.1111/j.1365-3091.1974.tb01793.x

Elliot, T., 1976, Upper Carboniferous sedimentary cycles produced by river-dominated, elongate deltas: Journal of the Geological Society of London, v. 132, no. 2, p. 199-208. doi:10.1144/gsigs.132.2.0199

Fiorillo, A.R., Decker, P.L., LePain, D.L., Wartes, M.A., and McCarthy, P.J., 2010, A probable Neoceratopsian manus track from the Nanushuk Formation (Albian, northern Alaska): Journal of Iberian Geology, v. 36, no. 2, p. 165-174. doi:10.5209/rev JIGE.2010.v36.n2.4

Fisher, W.L., Brown, L.F., Scott, A.J., and McGowan, J.A., 1969, Delta systems in the exploration for oil and gasA research colloquium: Austin, TX, The University of Texas at Austin, Bureau of Economic Geology, 78 p.

Fisk, H.N., 1947, Fine-grained alluvial deposits and their effects on Mississippi River activity: Vicksburg, MS,
U.S. Corps of Engineers, Waterway Experiment Station, v. II, 74 plates.

Fisk, H.N., Kolb, C.R., McFarlan, Edward, Jr., and Wilbert, L.J., Jr., 1954, Sedimentary framework of the modern Mississippi delta [Louisiana]: Journal of Sedimentary Petrology, v. 24, no. 2, p. 76-99.

Galloway, W.E., 1968, Depositional systems of the Lower Wilcox group, north-central Gulf Coast basin: Transactions-Gulf Coast Association of Geological Societies, v. 18, p. 275-289.

Galloway, W.E., and Hobday, D.K., 1996, Terrigenous clastic depositional systems: Berlin, Springer-Verlag, $489 \mathrm{p}$.

Greb, S.F., and Dever, G.R., 2002, Critical evaluation of possible seismites-Examples from the Carboniferous of the Appalachian basin, in Ettensohn, F.R., Rast, N.R., and Brett, C.E., eds., Ancient seismites: Geological Society of America Special Paper 359, p. 109-125.

Harms, J.C., Southard, J.B., Spearing, D.R., and Walker, R.G., 1975, Depositional environments as interpreted from primary sedimentary structures and stratification sequences: SEPM Short Course No. 2, lecture notes, $161 \mathrm{p}$.

Helmold, K.P., 2016 [this volume], Sedimentary petrology and reservoir quality of Lower Cretaceous Nanushuk sandstones, USGS Wainwright \#1 test well, western North Slope, Alaska, in LePain, D.L., ed., Stratigraphic and reservoir quality studies of continuous core from the Wainwright \#1 coalbed methane test well, Wainwright, Alaska: Alaska Division of Geological \& Geophysical Surveys Report of Investigation 2016-3, 56 p. doi:10.14509/29657

Ho, Clara, and Coleman, J.M., 1969, Consolidation and cementation of Recent sediments in the Atchafalaya basin: Geological Society of American Bulletin, v. 80, no. 2, p. 183-192.

Horn, J.C., Ferm, J.C., Caruccio, F.T., and Baganz, B.P., 1978, Depositional models in coal exploration and mine planning in Appalachian region: AAPG Bulletin, v. 62 , no. 12 , p. $2,379-2,411$. doi:10.1306/C1EA551216C9-11D7-8645000102C1865D

Houseknecht, D.W., and Schenk, C.J., 2001, Depositional sequences and facies in the Torok Formation, National Petroleum Reserve-Alaska (NPRA), in Houseknecht, D.W., ed., NPRA core workshop-Petroleum plays and systems in the National Petroleum ReserveAlaska: Society for Sedimentary Geology (SEPM) Core Workshop Notes, v. 21, p. 179-199. doi:10.2110/ cor.01.01.0179

Houseknecht, D.W., and Schenk, C.J., 2005, Sedimentology and sequence stratigraphy of the Cretaceous Nanushuk, Seabee, and Tuluvak Formations exposed on Umiat Mountain, north-central Alaska: U.S. Geological Survey Professional Paper 1709-B, 18 p.

Houseknecht, D.W., Bird, K.J., and Schenk, C.J., 2008, Seismic analysis of clinoform depositional sequences and shelf-margin trajectories in Lower Cretaceous (Albian) strata, Alaska North Slope: Basin Research, v. 21, no. 5, p. 644-654. doi:10.1111/i.1365-2117.2008.00392.x 
Howard, J.D, 1975, The sedimentological significance of trace fossils, in Frey, R.W., ed., The study of trace fossils: New York, Springer-Verlag, p. 131-146.

Huffman, A.C., Ahlbrandt, T.S., and Bartsch-Winkler, S., 1988, Sedimentology of the Nanushuk Group, North Slope, in Gryc, George, ed., Geology and exploration of the National Petroleum Reserve in Alaska, 1974 to 1982: U.S. Geological Survey Professional Paper 1399, p. 281-298. http://dggs.alaska.gov/pubs/id/4159

Huffman, A.C., Ahlbrandt, T.S., Pasternack, Ira, Stricker, G.D., and Fox, J.E., 1985, Depositional and sedimentologic factors affecting the reservoir potential of the Cretaceous Nanushuk Group, central North Slope, in Huffman, A.C., ed., Geology of the Nanushuk Group and related rocks, North Slope, Alaska: U.S. Geological Survey Bulletin 1614, p. 61-74. http://dggs.alaska. gov/pubs/id/4561

Jopling, A.V., and Walker, R.G., 1968, Morphology and origin of ripple-drift cross-lamination with examples from the Pleistocene of Massachusetts:Journal of Sedimentary Petrology, v. 38, no. 4, p. 971-984. doi:10.1306/74D71ADC2B21-11D7-8648000102C1865D

LePain, D.L., and Kirkham, R., 2001, Potential reservoir facies in the Nanushuk Formation (Albian-Cenomanian), central North Slope, Alaska-Examples from outcrop and core, in Houseknecht, D.W., ed., NPRA Core Workshop: Petroleum plays and systems in the National Petroleum Reserve - Alaska: SEPM Core Workshop No. 21, p. 19-36.

LePain, D.L., Decker, P.L., and Wartes, M.A., 2008, Measured sections and preliminary interpretations of the Nanushuk Formation exposed along the Colville River near the confluences with the Awuna and Killik rivers, in Wartes, M.A., and Decker, P.L., ed., Preliminary results of recent geologic field investigations in the Brooks Range foothills and North Slope, Alaska: Alaska Division of Geological \& Geophysical Surveys Preliminary Interpretive Report 2008-1D, p. 41-45, 4 sheets. doi:10.14509/16088

LePain, D.L., McCarthy, P.J., and Kirkham, Russell, 2009, Sedimentology and sequence stratigraphy of the middle Albian-Cenomanian Nanushuk Formation in outcrop, central North Slope, Alaska: Alaska Division of Geological \& Geophysical Surveys Report of Investigation 2009-1, 78 p., 1 sheet. doi:10.14509/19761

MacEachern, J.A., Bann, K.L., Pemberton, S.G., and Ginras, M.K., 2007a, The ichnofacies paradigm-High-resolution paleoenvironmental interpretation of the rock record, in MacEachern, J.A., Bann, K.L., Gingras, M.K., and Pemberton, S.G., eds., Applied ichnology: SEPM Short Course Notes 52, Tulsa, Oklahoma, p. 27-64.

MacEachern, J.A., Pemberton, S.G., Bann, K.L., and Ginras, M.K., 2007b, Departures from the archetypal ichnofacies-Effective recognition of physic-chemical stresses in the rock record, in MacEachern, J.A., Bann, K.L., Gingras, M.K., and Pemberton, S.G., eds., Applied ich- nology: SEPM Short Course Notes 52, Tulsa, Oklahoma, p. 65-93.

Mayfield, C.F., Tailleur, I.L., and Kirschner, C.E., 1988, Bedrock geologic map of the National Petroleum Reserve in Alaska, in Gryc, George, ed., Geology and exploration of the National Petroleum Reserve in Alaska, 1974 to 1982: U.S. Geological Survey Professional Paper 1399, p. 187-190, scale 1:500,000.

McCabe, P.J., 1984, Depositional environments of coal and coal-bearing strata, in Rahmani, R.A., and Flores, R.M, eds., Sedimentology of coal and coal-bearing sequences: International Association of Sedimentologists Special Paper 7, p. 13-42.

McCarthy, P.J., 2003, Alluvial facies and paleosols in the Cretaceous Nanushuk Formation, Kanayut River, North Slope, Alaska-Preliminary results from the 2001 field season: Alaska Division of Geological \& Geophysical Surveys Preliminary Interpretive Report 2003-1, 19 p. doi:10.14509/2920

Miall, A.D., 1996, The geology of fluvial deposits: Berlin, Springer-Verlag, $582 \mathrm{p}$.

Molenaar, C.M., 1985, Subsurface correlations and depositional history of the Nanushuk Group and related strata, North Slope, Alaska, in Huffman, A.C., ed., Geology of the Nanushuk Group and related rocks, North Slope, Alaska: U.S. Geological Survey Bulletin 1614, p. 37-59.

Molenaar, C.M., 1988, Depositional history and seismic stratigraphy of Lower Cretaceous rock in the National Petroleum Reserve in Alaska and adjacent areas, in Gryc, George, ed., Geology and exploration of the National Petroleum Reserve in Alaska, 1974 to 1982: U.S. Geological Survey Professional Paper 1399, p. 593-621.

Moore, T.E., Wallace, W.K., Bird, K.J., Karl, S.M., Mull, C.G., and Dillon, J.T., 1994, Geology of northern Alaska, in Plafker, G., and Berg, H.C., eds., The geology of Alaska: Geological Society of America, The Geology of North America, v. G-1, p. 49-140.

Mulder, Thierry, Syvitski, J.P.M., Migeon, Sebastien, Faugeres, J.-C., and Savoye, Bruno, 2003, Marine hyperpycnal flows-Initiation, behavior, and related deposits-A review: Marine and Petroleum Geology, v. 20, no. 6-8, p.861-882. doi:10.1016/j.marpetgeo.2003.01.003

Mull, C.G., 1985, Cretaceous tectonics, depositional cycles, and the Nanushuk Group, Brooks Range and Arctic Slope, Alaska, in Huffman, A.C., ed., Geology of the Nanushuk Group and related rocks, North Slope, Alaska: U.S. Geological Survey Bulletin 1614, p. 7-36. http:// dggs.alaska.gov/pubs/id/4559

Mull, C.G., Houseknecht, D.W., and Bird, K.J., 2003, Revised Cretaceous and Tertiary stratigraphic nomenclature in the Colville Basin, northern Alaska: U.S. Geological Survey Professional Paper 1673, 59 p. http://dggs. alaska.gov/pubs/id/4052

Nio, S.D., and Yang, C.S., 1991, Diagnostic attributes of clastic tidal deposits-A review, in Smith, D.G., Reinson, 
G.E., Zaitlin, B.A., and Rahmani, R.A., eds., Clastic tidal sedimentology: Canadian Society of Petroleum Geologists Memoir 16, p. 3-27.

Pemberton, S.G., and Wightman, D.M., 1992, Ichnological characteristics of brackish water deposits, in Pemberton, S.G., ed., Applications of ichnology to petroleum exploration-A core workshop: SEPM Core Workshop 17 , p. $141-167$.

Pemberton, S.G, Frey, R.W., Ranger, M.J., and MacEachern, J.A., 1992, The conceptual framework of ichnology, in Pemberton, S.G., ed., Applications of ichnology to petroleum exploration-A core workshop: SEPM Core Workshop 17, p. 1-32.

Potter, P.E., Maynard, J.B., and Depetris, P.J., 2005, Mud and mudstones-Introduction and overview: Berlin, Springer-Verlag, $297 \mathrm{p}$.

Ryer, T.A., and Anderson, P.B., 2002, Facies of the Ferron Sandstone [chapter 3], in Chidsey, T.C., ed., Geological and petrophysical characterization of the Ferron Sandstone for 3-D simulation of a fluvial-deltaic reservoir: Utah Geological Survey Miscellaneous Publication 02-6. www.mapstore.utah.gov/mp02-6.html
Simons, D.B., Richardson, E.V., and Nordin, C.F., Jr., 1965 Sedimentary structures generated by flow in alluvial channels, in Middleton, G.V., ed., Primary sedimentary structures and their hydrodynamic interpretation-A symposium: SEPM Special Publication, v. 12, p. 34-52. doi:10.2110/pec.65.08.0034

Southard, J.B., 1971, Representation of bed configurations in depth-velocity-size diagrams: Journal of Sedimentary Petrology, v. 41, no. 4, p. 903-915. doi:10.1306/74D723B0-2B21-11D7-8648000102C1865D

Thomas, R.G., Smith, D.G., Wood, J.M., Visser, John, Calverley-Range, E.A., and Koster, Emlyn, 1987, Inclined heterolithic stratification-Terminology, description, interpretation and significance: Sedimentary Geology, v. 53, no. 1-2, p. 123-179. doi:10.1016/\$00370738(87)80006-4

Walker, R.G., 1984, Shelf and shallow marine sands, in Walker, R.G., ed., Facies models, 2nd edition: Geoscience Canada Reprint Series 1, p. 141-170. 



\title{
SEDIMENTARY PETROLOGY AND RESERVOIR QUALITY OF ALBIAN- CENOMANIAN NANUSHUK FORMATION SANDSTONES, USGS WAINWRIGHT \#1 TEST WELL, WESTERN NORTH SLOPE, ALASKA
}

\author{
Kenneth P. Helmold ${ }^{1}$
}

\section{INTRODUCTION}

The U.S. Geological Survey (USGS) conducted a project in 2007 (Clark, 2014) to evaluate the coalbed methane potential of the Albian-Cenomanian Nanushuk Formation as a reliable source of energy for the village of Wainwright, located southwest of Barrow on the Beaufort Sea coast (fig. 3-1). As part of this project the USGS Wainwright \#1 test well was drilled, which included $1,530 \mathrm{ft}$ of continuous core from a depth of 75 to $1,605 \mathrm{ft}$. The analytical program included sampling and measuring the gas content of coals that could have potential as a coalbed methane resource. The sedimentology of the core was documented by LePain and Decker (2016 [this volume]); the regional subsurface context for this core is presented by Decker and LePain (2016 [this volume]). As a parallel study, this report documents the sedimentary petrology and reservoir quality of the Nanushuk siltstones and sandstones encountered in the well.

\section{REGIONAL FRAMEWORK}

The Nanushuk Formation is a thick succession of marine, transitional, and nonmarine strata of Albian to Cenomanian age deposited in the asymmetrical Colville foreland basin (fig. 3-2). The formation is present in outcrop in a belt $30-50 \mathrm{~km}$ wide and roughly $650 \mathrm{~km}$ long in the northern foothills of the Brooks Range. The Nanushuk includes a lower, dominantly marine succession of shale, siltstone, and sandstone deposited in shelf, deltaic, and shoreface settings. The lower unit is gradationally overlain by a dominantly nonmarine succession of mudstone, coal, sandstone, and conglomerate deposited in lower delta plain and alluvial settings (Huffman and others, 1985; LePain and others, 2009; Mull and others, 2003). Together these units form a thick regressive package punctuated by marine transgressions resulting from channel avulsion and subsidence of the abandoned delta lobes (LePain and others, 2009) and episodic pulses of basin subsidence (Molenaar, 1985). The uppermost beds of the Nanushuk consist of a Cenomanian mixed marine, marginal-marine, and nonmarine succession deposited during a regional transgressive episode that culminated in termination of fluvial and deltaic deposition and the re-establishment of widespread marine shelf conditions throughout the central and western North Slope, and deposition of the Turonian Seabee Formation (LePain and others, 2009; Molenaar, 1985).
Early Cretaceous uplift of the Brooks Range resulted in clastic detritus shed into the foreland basin from southern and southwestern terranes. These deposits include the deepwater to nonmarine Fortress Mountain Formation, deepwater turbidites of the Torok Formation, and coeval shallow marine to nonmarine strata of the Nanushuk Formation. The Torok and Nanushuk Formations collectively represent the transition from an underfilled to an overfilled basin (LePain and others, 2009), with Nanushuk strata eventually breaching the Barrow arch in the late Albian (Molenaar, 1985). Regional studies suggest Nanushuk deposition occurred in three large deltaic complexes separated by the north-south-trending Meade arch (Ahlbrandt and others, 1979; Huffman and others, 1985). The Corwin delta is west of the arch and was interpreted to be the product of river-dominated systems (Ahlbrandt and others, 1979; Huffman and others, 1985). It was sourced from a large drainage basin that extended west of present-day Arctic Alaska (Molenaar, 1985). East of the arch, two delta complexes, the Kurupa-Umiat and Grandstand-Marmot deltas, were recognized as river-dominated systems with a greater degree of wave influence (Ahlbrandt and others, 1979; Huffman and others, 1985) and have been reinterpreted as wave-modified to wave-dominated deltas (LePain and others, 2009). They were fed by north-flowing rivers draining smaller catchment areas in the ancestral Brooks Range to the south (Huffman and others, 1985; LePain and others, 2009). Initial work on the petrology of these deltaic systems, with emphasis on mineralogy, reservoir quality, provenance, and petroleum potential, was conducted by Bartsch-Winkler $(1979,1985)$, Bartsch-Winkler and Huffman (1988), and Johnsson and Sokol (2000). Reservoir quality of the Nanushuk sandstones was previously investigated by Reifenstuhl and Loveland (2004). The collective Nanushuk deltaic deposits, along with coeval slope and basinal deposits of the Torok Formations, fill the western portion of the Colville basin (Houseknecht and Schenk, 2001; Houseknecht and others, 2008).

\section{DATASETS}

Fifty-one (51) plugs were cut from the conventional core and submitted to Weatherford Laboratories for routine core analysis. The analyses were run under a net confining stress of $400 \mathrm{psi}$. Because of the rubbly nature of some of the plugs, complete petrophysical data (porosity, permeability, and grain density) could only be obtained for 46 samples (appendices 3-A, 3-B). Trimmed end-cuts 

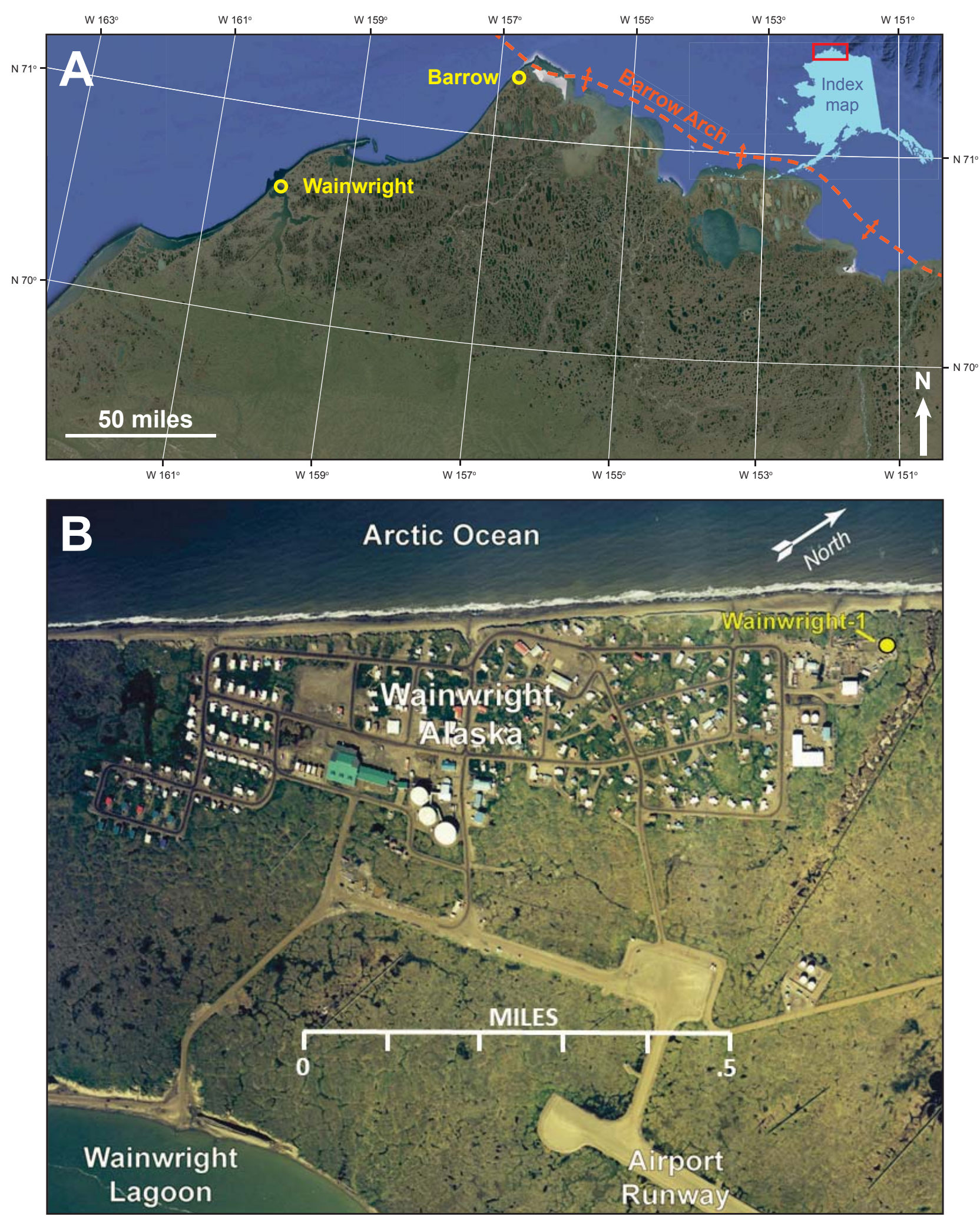

Figure 3-1. A. Google Earth satellite image, showing the location of the villages of Wainwright and Barrow on the North Slope of Alaska. Inset index map of Alaska shows the location of the satellite image. B. Aerial photograph of Wainwright, showing the location of the Wainwright \#1 test well (from Clark, 2014). 
from the plugs were submitted to Petrographics, Inc., of Montrose, CO, for preparation of standard petrographic thin sections. The samples were impregnated with epoxy spiked with both blue and fluorescent dyes prior to thinsection preparation. After initial inspection, 48 sandstones and siltstones were selected for modal analyses, which were performed by Michael D. Wilson of Wilson \& Associates. He counted a minimum of 400 points using the traditional (non Gazzi-Dickinson) point-counting method
(Ingersoll and others, 1984; Decker and Helmold, 1985) to determine the composition of the framework (detrital grains) and intergranular components (matrix, cement, porosity). The modal analyses are presented in two formats: (1) raw counts of Wilson (appendix 3-C), and (2) standardized hierarchical categories originally devised by Decker (1985) and modified by Helmold in subsequent years (appendix 3-D). All interpreted data, plots, and tables in this report are based on the Decker-Helmold

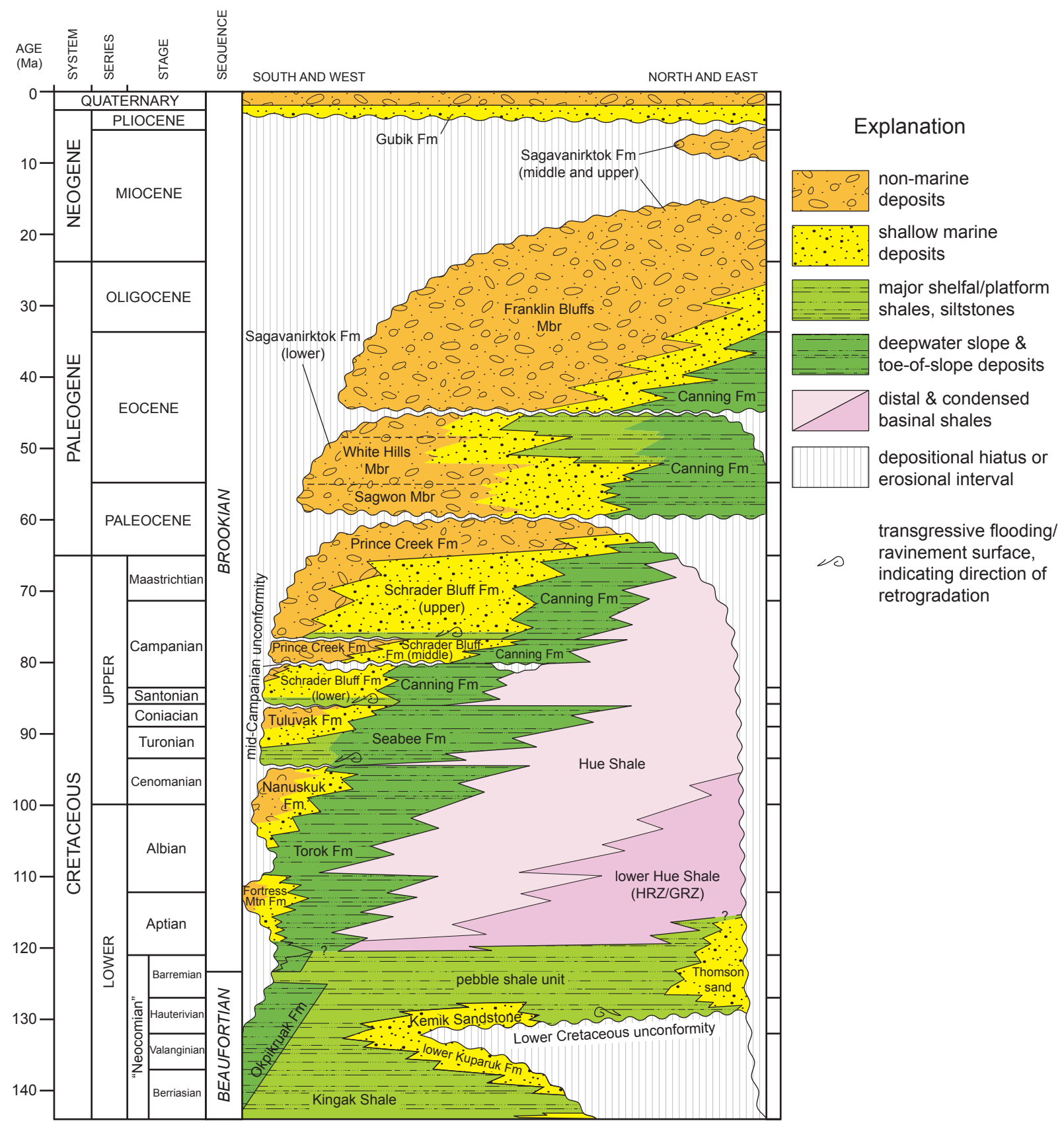

Figure 3-2. Chronostratigraphic column for the Colville basin, Alaska, showing the stratigraphic position of the Nanushuk Formation; revised from Mull and others (2003), Garrity and others (2005), Decker (2010), and Gillis and others (2014). Abbreviations as follows: Fm = Formation; Mbr = Member; Mtn = Mountain; HRZ = Highly radioactive zone; GRZ = Gamma-ray zone. 
system. Summaries of the modal data, standard petrologic parameters, and ternary ratios are presented in appendix 3-E, and petrographic ratios used to construct ternary diagrams are listed in appendix 3-F.

Wilson conducted a second count of 100 grains (including matrix) for each sample for grain size. A complete listing of the grain-size data, in both millimeter and $\varphi$ (phi) units, is presented in appendix 3-G. The original composition and grain-size files provided by Wilson and a file containing the composition data in DeckerHelmold format are available from the DGGS website (doi:10.14509/29657).

\section{PETROLOGIC FACIES}

As part of the detailed core description, LePain and Decker (2016 [this volume]) assigned sedimentologic facies to horizons from which plugs were taken for petrologic and routine core analyses (appendix 3-A, Core Facies). These designations were based largely on sedimentologic characteristics, primarily grain size and sedimentary structures. In several instances the assignments were equivocal because more than one facies was present in close proximity to the sampled horizons. To better integrate the sedimentologic (LePain and Decker, 2016 [this volume]) and petrologic analyses, the thin sections were examined and samples were reassigned to a sedimentary facies based on combined petrologic and sedimentologic criteria (appendix 3-A, TS Facies). The petrology of some of these facies groups were fairly similar, while other facies exhibited significant within-group variability in petrologic parameters. It was therefore decided to analyze the petrology of the samples independent from their sedimentology. The relationship between sedimentary facies and petrofacies is tabulated in table 3-1.

Two samples are heavily carbonate cemented and were assigned to a separate group, which was excluded from further statistical analyses. The remaining samples were grouped into petrofacies using the statistical capabilities of Data Desk, a statistical software application produced by Data Description, Inc. (Velleman, 1998). Fifty-five variables describing petrographic attributes including texture (such as grain size, sorting), composition (such as grain types, matrix, cements), and reservoir quality (such as porosity, permeability, intergranular volume) were amassed into a database. In several cases, mathematical transformations of variables (for example, logarithms of permeability and grain size) were also included. The variables were evaluated to determine suitability for use in allocating samples to petrofacies. Some variables (for example, 'glauconite') contained null values for most of the samples, signifying the absence of glauconite. Other variables (for example, 'quartz cement') contained similar values for most of the samples, resulting in low standard deviations and little discriminating power. The 25 most significant variables were statistically compared with each other to ascertain which pairs had the greatest positive or negative correlation (table 3-2). Three of the most highly correlated variables, representing texture, composition, and reservoir quality, were designated as grouping variables. Grain size (measured in millimeters) was selected to represent texture, bulk chert content to represent composition, and thin-section porosity as a proxy for reservoir quality. Thin-section porosity was chosen over routine (measured) porosity, which was more highly correlated with grain size, so that all three parameters could be ascertained directly from point-count analyses. The three parameters were displayed on a rotating plot in Data Desk (fig. 3-3), which provides an intuitive means to investigate relationships among three variables without using statistical analyses (Velleman, 1998). This fully rotatable plot was studied in all three dimensions to search for clustering of the data into distinct groups. If clusters were apparent, the plot was rotated until maximum separation was obtained among the samples, at which point they were assigned to individual groups (Velleman, 1998). Using this methodology, the samples were assigned to one of four petrofacies; the two cemented samples were allocated to a fifth petrofacies. The petrofacies are designated: (1) Siltstone petrofacies, (2) Very-fine-grained sandstone petrofacies, (3) Fine-grained sandstone petrofacies, (4) Medium-grained sandstone petrofacies, and (5) Carbonate-cemented sandstone petrofacies. The compositions of the petrofacies are illustrated in a series of ternary diagrams (fig. 3-4), their texture is displayed in a plot of cumulative grain size (fig. 3-5), and representative photomicrographs are shown in

Table 3-1. Relationship between sedimentologic facies and petrofacies. Key to sedimentologic facies: SIf = plane-parallel laminated fine-grained sandstone; SIm = plane-parallel laminated medium-grained sandstone; Sx = cross-bedded sandstone; $\mathrm{Sm}=$ massive sandstone; $\mathrm{Sr}=$ ripple cross-laminated sandstone; $\mathrm{Scb}=$ convolute laminated sandstone; SFh = heterolithic sandstone and mudstone; $\mathrm{Fm}=$ massive mudstone.

$\begin{array}{lrrr} & \text { SIf } & \text { SIm } & \text { Sx } \\ \text { Cemented sandstone } & 0 & 0 & 0 \\ \text { Siltstone } & 1 & 0 & 0 \\ \text { Very-fine sandstone } & 9 & 0 & 0 \\ \text { Fine sandstone } & 2 & 12 & 4 \\ \text { Medium sandstone } & 0 & 3 & 0 \\ \text { Total } & \mathbf{1 1} & \mathbf{1 5} & \mathbf{4}\end{array}$

\begin{tabular}{rrrrrr}
\multicolumn{5}{c}{ Sedimentologic Facies } & \\
Sm & Sr & Scb & SFh & Fm & Total \\
1 & 1 & 0 & 0 & 0 & 2 \\
0 & 3 & 3 & 0 & 2 & 9 \\
0 & 5 & 0 & 2 & 0 & 16 \\
3 & 0 & 0 & 0 & 0 & 21 \\
0 & 0 & 0 & 0 & 0 & 3 \\
$\mathbf{3}$ & $\mathbf{1 0}$ & $\mathbf{3}$ & $\mathbf{2}$ & $\mathbf{3}$ & $\mathbf{5 1}$
\end{tabular}




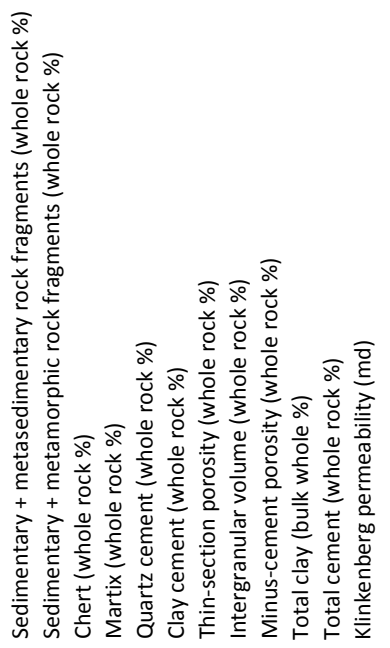

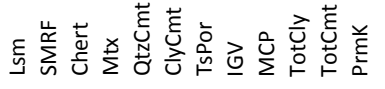

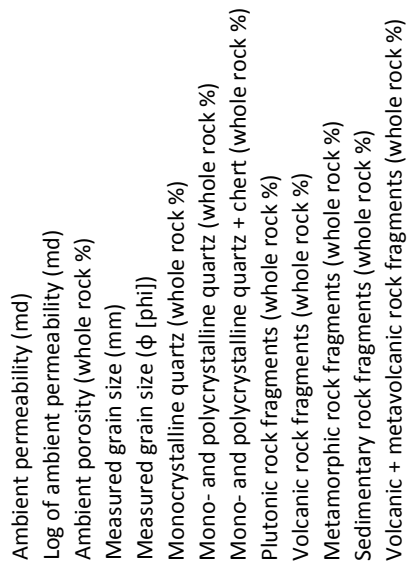

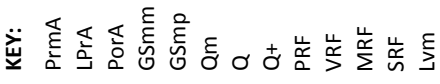


figs. 3-6-3-10. The relationship between the petrofacies and sedimentologic facies of LePain and Decker (2016 [this volume]) are presented in table 3-1.

To assess how these petrofacies compare to other Nanushuk sandstones in terms of composition, texture, and reservoir quality, data from 25 North Slope exploration wells (table 3-3) are included in the various scatter and ternary plots.

\section{SILTSTONE PETROFACIES}

The siltstone petrofacies is represented by nine samples (only six were point-counted) that typically consist of laminated, clay-rich siltstones with a fairly high clay content (fig. 3-6). They have an average modal composition of $\mathrm{Q}_{\mathrm{t71}} \mathrm{F}_{14} \mathrm{~L}_{15}, \mathrm{Q}_{\mathrm{m} 57} \mathrm{~F}_{14} \mathrm{~L}_{\mathrm{t} 29}, \mathrm{Q}_{\mathrm{m} 80} \mathrm{P}_{12} \mathrm{~K}_{8}, \mathrm{Q}_{\mathrm{p} 49} \mathrm{~L}_{\mathrm{vm} 4} \mathrm{~L}_{\mathrm{sm} 46}$ (fig. 3-4, appendix 3-F), and a plagioclase/total feldspar (P/F) ratio of 0.61 . The average grain size (fig. 3-5, appendix 3-G) of the siltstones is $0.011 \mathrm{~mm}$ (fine silt), with an average Folk sorting (Folk, 1974) of 3.39 (very poor). Their framework composition is dramatically different from the sandstones, owing largely to their finer grain size (see section on petrologic trends, below). Monocrystalline quartz $\left(\mathrm{Q}_{\mathrm{m}}\right)$ is the single-most-abundant detrital grain, averaging 48 percent of the framework fraction. Chert is a minor detrital component (4 percent of framework), in contrast to the coarser-grained detritus in which it is more abundant. Feldspar comprises approximately 12 percent of the framework and consists of roughly equal proportions of plagioclase and K-feldspar. Sedimentary rock fragments (SRFs), consisting largely of detrital carbonate, mudstone, and argillite, are the dominant lithic component (average 8 percent of framework), with lesser amounts of felsic volcanic and plutonic grains, phyllite, and quartzite. Micas (average 3.5 percent) and organic material (average 6 percent) are more abundant than in the sandstones, based on their hydrodynamic equivalence with the finer detritus.

Overall reservoir quality of the siltstones is moderately poor to poor with an average air permeability of $1.22 \mathrm{md}$ (0.96 md Klinkenberg permeability) and average porosity of 15 percent (fig. 3-11). They contain significant detrital clay matrix (average 37 percent), which has a pronounced effect on reservoir quality, particularly permeability

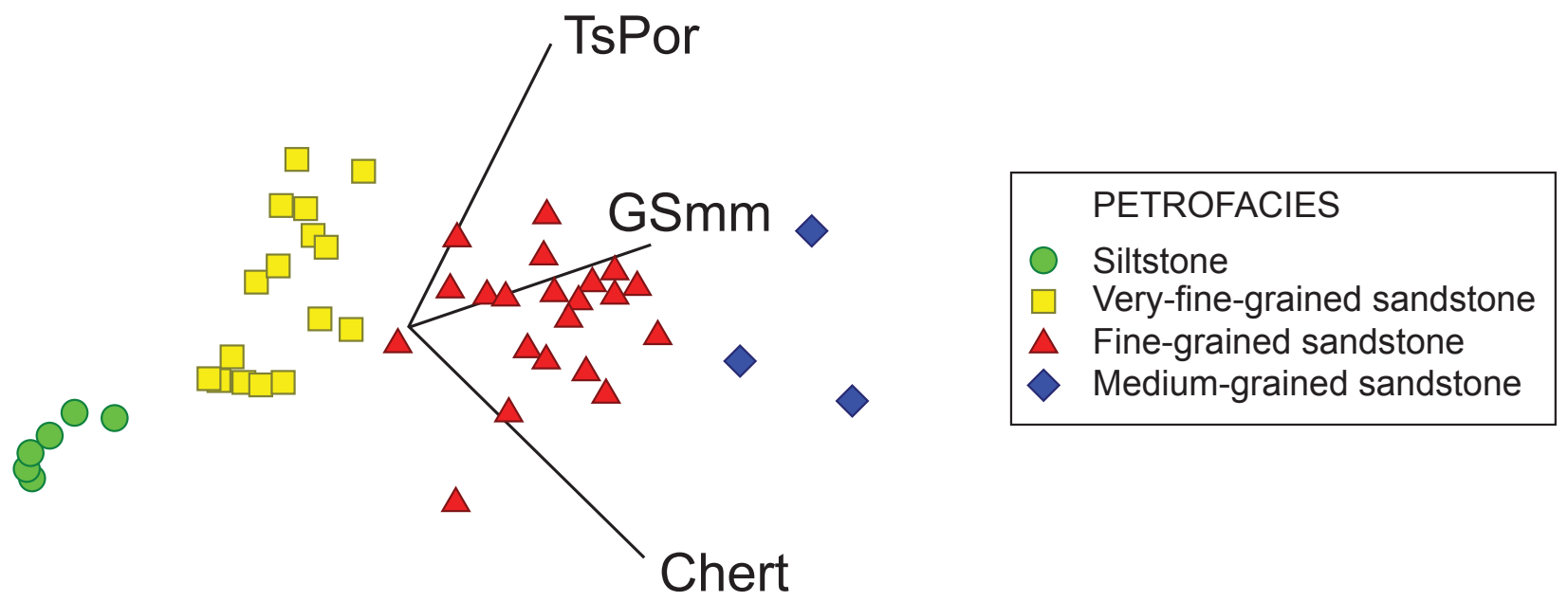

Figure 3-3. Static image of rotating plot used to assign samples to one of four petrofacies. Variables are thin-section porosity (\%), grain size $(\mathrm{mm})$, and chert content (\%). The cemented sandstones are excluded from this plot and assigned to a fifth petrofacies. This plot, which is fully rotatable in the Data Desk environment, provides an intuitive means to investigate relationships among three variables without using statistical analyses. Typically the plot is rotated in all three dimensions until maximum separation is obtained among the samples, at which point they can be assigned to individual groups.

Figure 3-4 (right). Ternary diagrams showing composition of Nanushuk sandstones. The data were obtained via the traditional point-counting method in which phaneritic rock fragments are classified as the appropriate lithology (for example, granite, diorite, gabbro, gneiss). See table 3-4 for explanation of grain and intergranular parameters used in the diagrams. A. $Q_{t} F L$ diagram; most samples plot in the litharenite, feldspathic litharenite, and lithic arkose fields of Folk (1974). Chert is apportioned to the $Q_{t}$ pole, resulting in samples grouping closer to that pole. $\mathbf{B}$. $Q_{m} F L_{t}$ diagram; all samples plot in the litharenite and feldspathic litharenite fields of Folk (1974). Chert is apportioned to the $L_{t}$ pole, resulting in a wide data spread with coarser-grained samples closer to that pole and siltstones closer to the $Q_{m}$ pole. $\mathbf{C}$. $Q_{m} P K$ diagram; the siltstones contain more monocrystalline quartz and therefore plot closer to the $\mathrm{Q}_{m}$ pole. Most samples contain slightly more plagioclase than K-feldspar. D. $Q_{p} L_{v m} L_{s m}$ diagram; all samples plot along the $Q_{p}-L_{s m}$ join, indicating a relative paucity of volcanic and metavolcanic detritus. E. $L_{s} L_{v} L_{m}$ diagram; the lithic population of all samples consists largely of sedimentary rock fragments (SRF). This trend is partially due to the inclusion of chert with the SRFs. F. фCM diagram; the siltstones are enriched in matrix, resulting in poor reservoir quality. The medium- and fine-grained sandstones are most porous; the two cemented sandstones lack any thin-section porosity. 

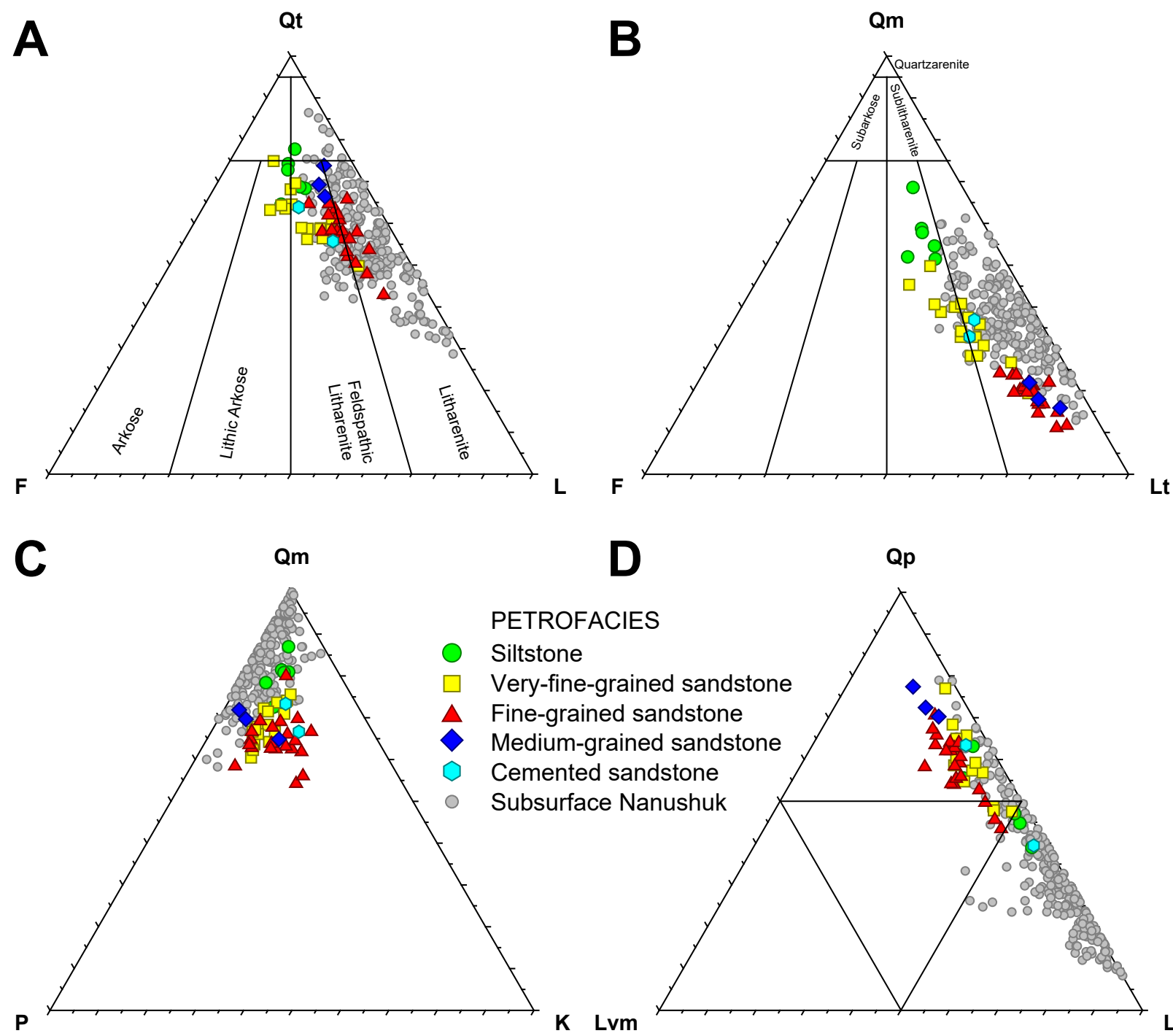

D
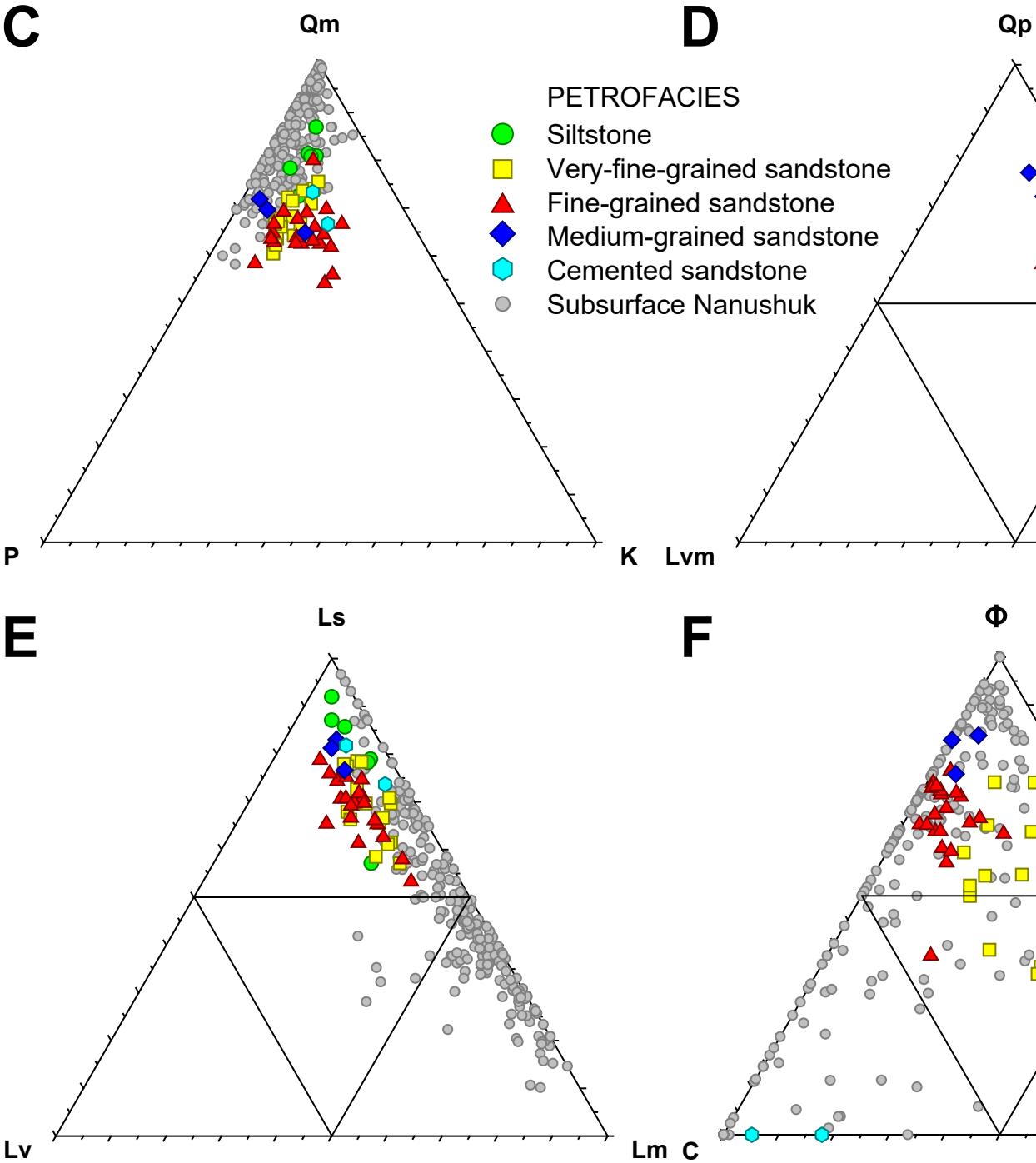

K Lvm

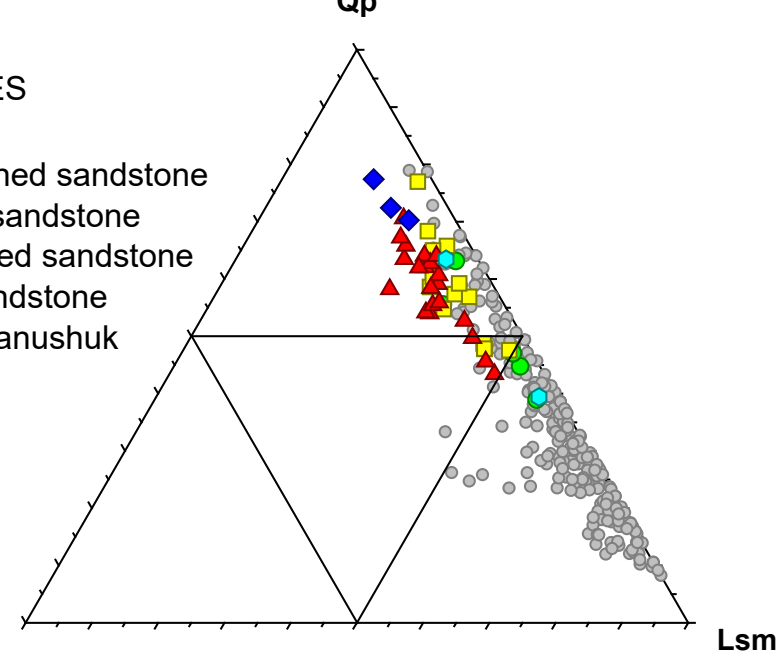

$\mathbf{F}$

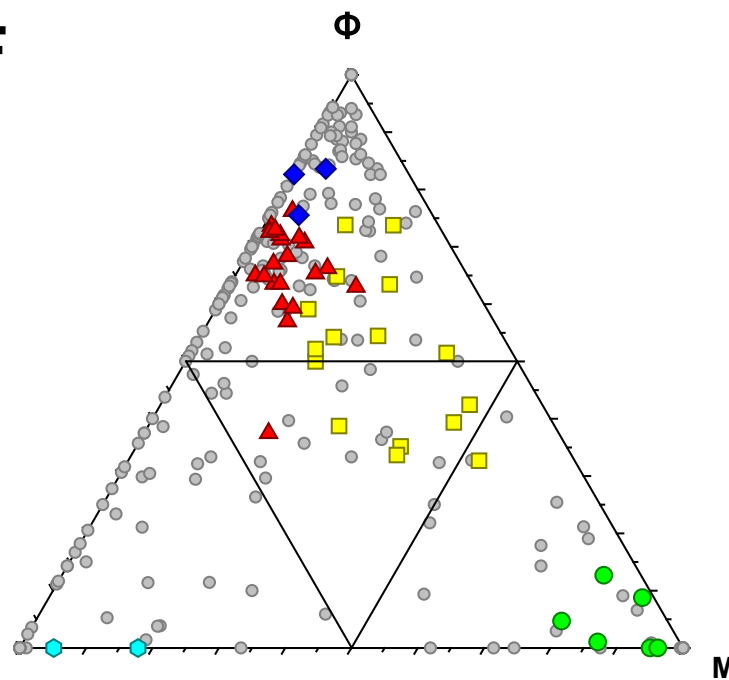


(Neasham, 1977; Howard, 1992). Siderite is a minor cement with a patchy distribution (varies from 0.5 to 6 percent of bulk rock; average 3 percent). The intergranular volume (IGV) is high (average 41 percent), largely due to the abundant matrix.

One sample of this petrofacies belongs to the planeparallel laminated sandstone (Slf) facies, three to the ripple cross-laminated sandstone ( $\mathrm{Sr}$ ) facies, three to the convolute laminated sandstone ( $\mathrm{Scb}$ ) facies, and two to the massive mudstone (Fm) facies (table 3-1).
VERY-FINE-GRAINED SANDSTONE PETROFACIES

The very-fine-grained sandstone petrofacies is represented by 16 feldspathic litharenites and litharenites (figs. 3-4 and 3-7). They have an average modal composition of $\mathrm{Q}_{\mathrm{t} 62} \mathrm{~F}_{16} \mathrm{~L}_{22}, \mathrm{Q}_{\mathrm{m} 35} \mathrm{~F}_{16} \mathrm{~L}_{\mathrm{t} 49}, \mathrm{Q}_{\mathrm{m} 68} \mathrm{P}_{21} \mathrm{~K}_{11}, \mathrm{Q}_{\mathrm{p} 59} \mathrm{~L}_{\mathrm{vm} 6} \mathrm{~L}_{\mathrm{sm} 35}$ (fig. 3-4, appendix 3-F), and a plagioclase/total feldspar (P/F) ratio of 0.66 . Their average grain size (fig. 3-5, appendix $3-\mathrm{G}$ ) is $0.08 \mathrm{~mm}$ (lower very fine), with an average Folk sorting (Folk, 1974) of 1.83 (poor). Monocrystalline $\left(\mathrm{Q}_{\mathrm{m}}\right)$ and polycrystalline $\left(\mathrm{Q}_{\mathrm{p}}\right)$ quartz are the two dominant framework components, averaging 31 and 12 percent of
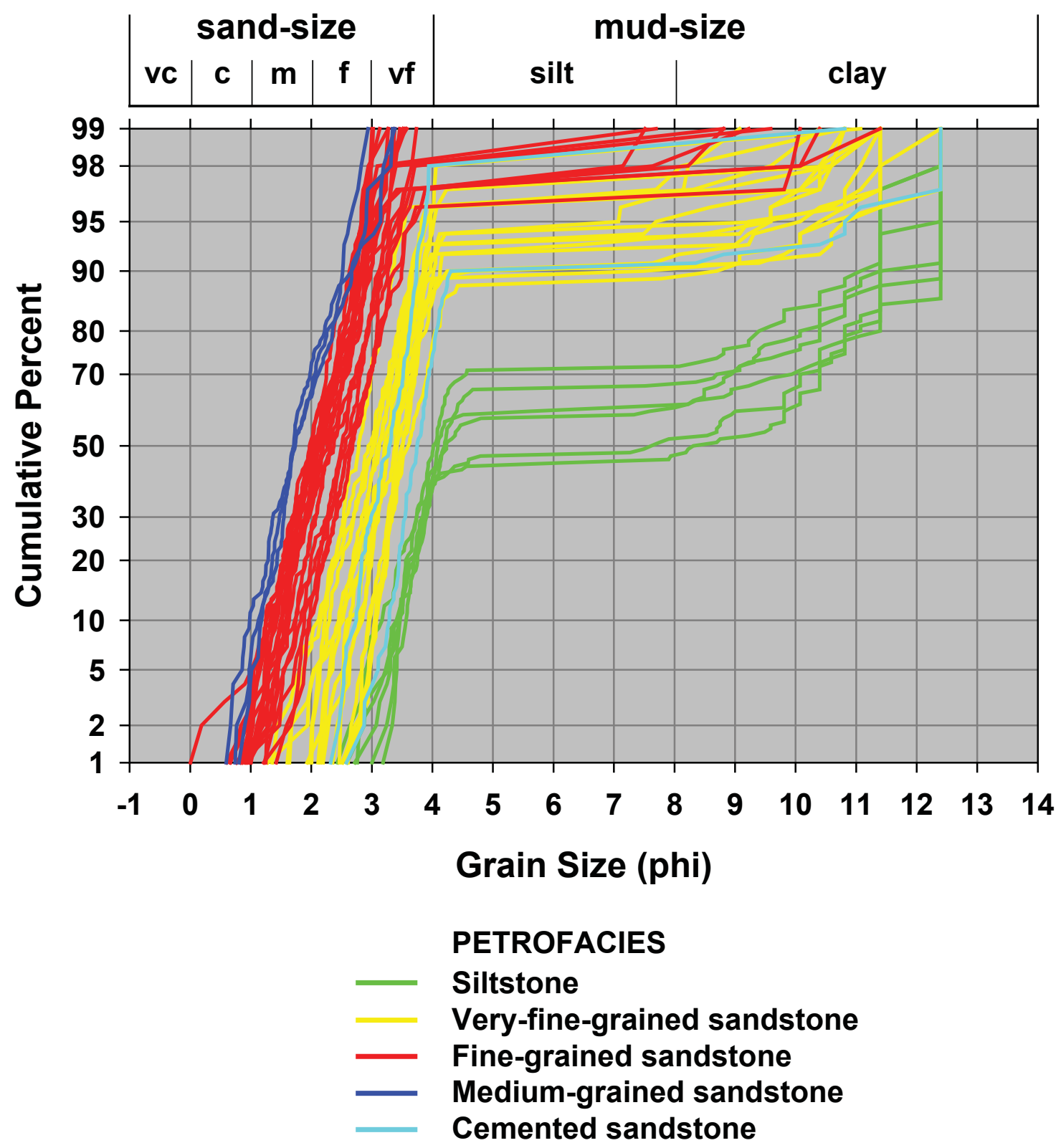

Figure 3-5. Cumulative probability plots of grain size by petrofacies; each line represents a single sample. Samples with a normal (Gaussian) distribution plot as a straight line; right-directed tails indicate abundant matrix (both silt and clay). The value of the 50th percentile indicates median grain size, while the slope of the line indicates sorting. 
Table 3-3. Wells for which data are included in scatter and ternary plots. Erosion estimates are derived from Burns and others, 2005.

\begin{tabular}{|c|c|c|c|c|c|c|c|}
\hline Number & Operator & Well & API & $\begin{array}{c}\text { Top Zone } \\
\text { (feet) }\end{array}$ & $\begin{array}{l}\text { Base Zone } \\
\text { (feet) }\end{array}$ & $\mathbf{N}$ & $\begin{array}{c}\text { Erosion } \\
\text { (feet) }\end{array}$ \\
\hline 1 & U.S. Navy & Barrow Core Test 1 & 50023100050000 & 169.0 & 194.0 & 6 & 2,725 \\
\hline 2 & Arco & Big Bend 1 & 50287200110000 & $1,100.0$ & $2,830.0$ & 9 & 8,002 \\
\hline 3 & Husky & E Simpson 2 & 50279200070000 & $2,387.0$ & $2,398.0$ & 9 & 1,785 \\
\hline 4 & U.S. Navy & Fish Ck 1 & 50103100010000 & $2,970.6$ & $3,032.9$ & 5 & 1,103 \\
\hline 5 & U.S. Navy & Grandstand 1 & 50057100010000 & 227.5 & $1,068.0$ & 22 & 8,084 \\
\hline 6 & Arco & Hunter A & 50103204050000 & $3,625.0$ & $3,652.0$ & 7 & 2,068 \\
\hline 7 & Husky & Inigok 1 & 50279200030000 & $2,632.0$ & $3,081.9$ & 7 & 3,223 \\
\hline 8 & U.S. Navy & Knifeblade 1 & 50119100120000 & 312.0 & $1,490.0$ & 6 & 6,777 \\
\hline 9 & $\mathrm{BP}$ & Kuparuk Unit 1 & 50287100180000 & $5,529.0$ & $5,920.0$ & 9 & 7,090 \\
\hline 10 & Sinclair & Little Twist Unit 1 & 50287100220000 & 942.0 & $3,609.0$ & 4 & 8,895 \\
\hline 11 & U.S. Navy & Meade 1 & 50163100020000 & $1,795.0$ & $2,950.0$ & 2 & 4,560 \\
\hline 12 & U.S. Navy & Oumalik Test 1 & 50119100050000 & 916.0 & $2,758.3$ & 17 & 4,711 \\
\hline 13 & Husky & Seabee 1 & 50287200070000 & 270.0 & $2,110.0$ & 7 & 6,564 \\
\hline 14 & BP & Trailblazer A1 & 50103203640000 & $2,972.0$ & $3,454.0$ & 4 & 1,402 \\
\hline 15 & BP & Trailblazer H1 & 50103203690000 & $2,760.0$ & $3,090.0$ & 3 & 1,525 \\
\hline 16 & U.S. Navy & Topagoruk 1 & 50279100330000 & 302.0 & $2,097.0$ & 10 & 2,748 \\
\hline 17 & Texaco & Tulugak 1 & 50057200010000 & $1,700.0$ & $2,510.0$ & 3 & 8,030 \\
\hline 18 & Husky & Tunalik 1 & 50301200010000 & $3,288.0$ & $5,560.6$ & 2 & 3,036 \\
\hline 19 & U.S. Navy & Umiat Test 11 & 50287100110000 & $2,048.0$ & $2,992.0$ & 37 & 6,301 \\
\hline 20 & U.S. Navy & Umiat Test 1 & 50287100010000 & $1,335.0$ & $2,996.0$ & 6 & 6,614 \\
\hline 21 & U.S. Navy & Umiat Test 2 & 50287100020000 & 413.0 & 969.0 & 4 & 6,469 \\
\hline 22 & U.S. Navy & Umiat Test 7 & 50287100070000 & 834.0 & $1,370.0$ & 5 & 6,543 \\
\hline 23 & U.S. Navy & Umiat Test 8 & 50287100080000 & 507.0 & 711.0 & 2 & 6,374 \\
\hline 24 & U.S. Navy & Wolf Ck 2 & 50119100090000 & $2,511.0$ & $3,520.0$ & 20 & 7,071 \\
\hline 25 & U.S. Navy & Wolf Ck 3 & 50119100100000 & $1,660.0$ & $2,362.0$ & 17 & 7,191 \\
\hline
\end{tabular}

Table 3-4. Classification of grain and intergranular parameters.
A. Quartzose grains
C. Lithic grains
$\mathrm{Q}_{\mathrm{m}}=$ Monocrystalline quartz
$L_{s}=$ Sedimentary rock fragments (including chert)
$Q_{p}=$ Polycrystalline quartz (including chert)
$L_{v}=$ Volcanic rock fragments
$Q_{t}=$ Total quartzose grains $\left(Q_{m}+Q_{p}+\right.$ chert $)$
$\mathrm{Lm}_{\mathrm{m}}=$ Metamorphic rock fragments
$L_{p}=$ Plutonic rock fragments
B. Feldspar grains
$\mathrm{P}=$ Plagioclase
$\mathrm{K}=$ Potassium feldspar
$F=$ Total feldspar grains $(P+K)$
$\mathrm{L}_{\mathrm{sm}}=$ Sedimentary and metasedimentary rock fragments
$\mathrm{Lvm}_{\mathrm{v}}=$ Volcanic and metavolcanic rock fragments
$L=$ Lithic grains $\left(L_{s}+L_{v}+L_{m}+L_{p}\right)$
$L_{t}=$ Total lithic grains $\left(L+Q_{p}\right)$
D. Intergranular components
$\phi=$ Total porosity
$\mathrm{C}=$ Total cement
$M=$ Matrix + clay laminae $/$ burrows 
the framework fraction, respectively. Other significant detrital components include chert (11 percent), plagioclase (9 percent), and $\mathrm{K}$-feldspar (5 percent). Lithic detritus consists largely of sedimentary (detrital carbonate, mudstone, argillite) and metamorphic (phyllite, quartzite) rock fragments. Organic matter and micas are accessory detrital components.

Overall reservoir quality of the very-fine-grained sandstones is good to very good with an average air permeability of $43 \mathrm{md}$ ( $36 \mathrm{md}$ Klinkenberg permeability) and average porosity of 23 percent (fig. 3-11). They typically are lightly cemented, containing an average of 3 percent carbonate cements, mostly siderite and minor ankerite. Kaolinite is a patchy, pore-filling cement averaging 1 percent of the bulk rock; a few overgrowths (<1 percent) were observed on detrital quartz grains. Detrital matrix is variable, ranging from 3 to 12 bulk percent, sometimes concentrated along diffuse laminae. The average intergranular volume (IGV) is 24 percent, similar to that of the other sandstones.
Nine samples of this petrofacies belong to the planeparallel laminated sandstone (Slf) facies, five to the ripple cross-laminated sandstone (Sr) facies, and two to the heterolithic sandstone and mudstone (SFh) facies (table 3-1).

\section{FINE-GRAINED SANDSTONE PETROFACIES}

The fine-grained sandstone petrofacies is represented by 21 chert-rich litharenites (fig. 3-8). They have an average modal composition of $\mathrm{Q}_{\mathrm{t} 57} \mathrm{~F}_{11} \mathrm{~L}_{32}, \mathrm{Q}_{\mathrm{m} 19} \mathrm{~F}_{10} \mathrm{~L}_{\mathrm{t} 71}, \mathrm{Q}_{\mathrm{m} 64} \mathrm{P}_{21} \mathrm{~K}_{15}$, $\mathrm{Q}_{\mathrm{p} 55} \mathrm{~L}_{\mathrm{vm} 9} \mathrm{~L}_{\mathrm{sm} 32}$ (fig. 3-4, appendix 3-F), and a plagioclase/ total feldspar $(\mathrm{P} / \mathrm{F})$ ratio of 0.59 . The average grain size (fig. 3-5, appendix 3-G) of this petrofacies is $0.20 \mathrm{~mm}$ (upper fine), with an average Folk sorting (Folk, 1974) of 0.97 (moderate). Chert and monocrystalline quartz $\left(\mathrm{Q}_{\mathrm{m}}\right)$ with dominantly straight to slightly undulose extinction are the two dominant framework components, averaging 26 and 17 percent of the framework fraction, respectively. Chert is largely of the common microcrystalline variety; other varieties include micaceous-argillaceous, calcareous-dolomitic, and microporous chert. Polycrystalline quartz $\left(\mathrm{Q}_{\mathrm{p}}\right)$
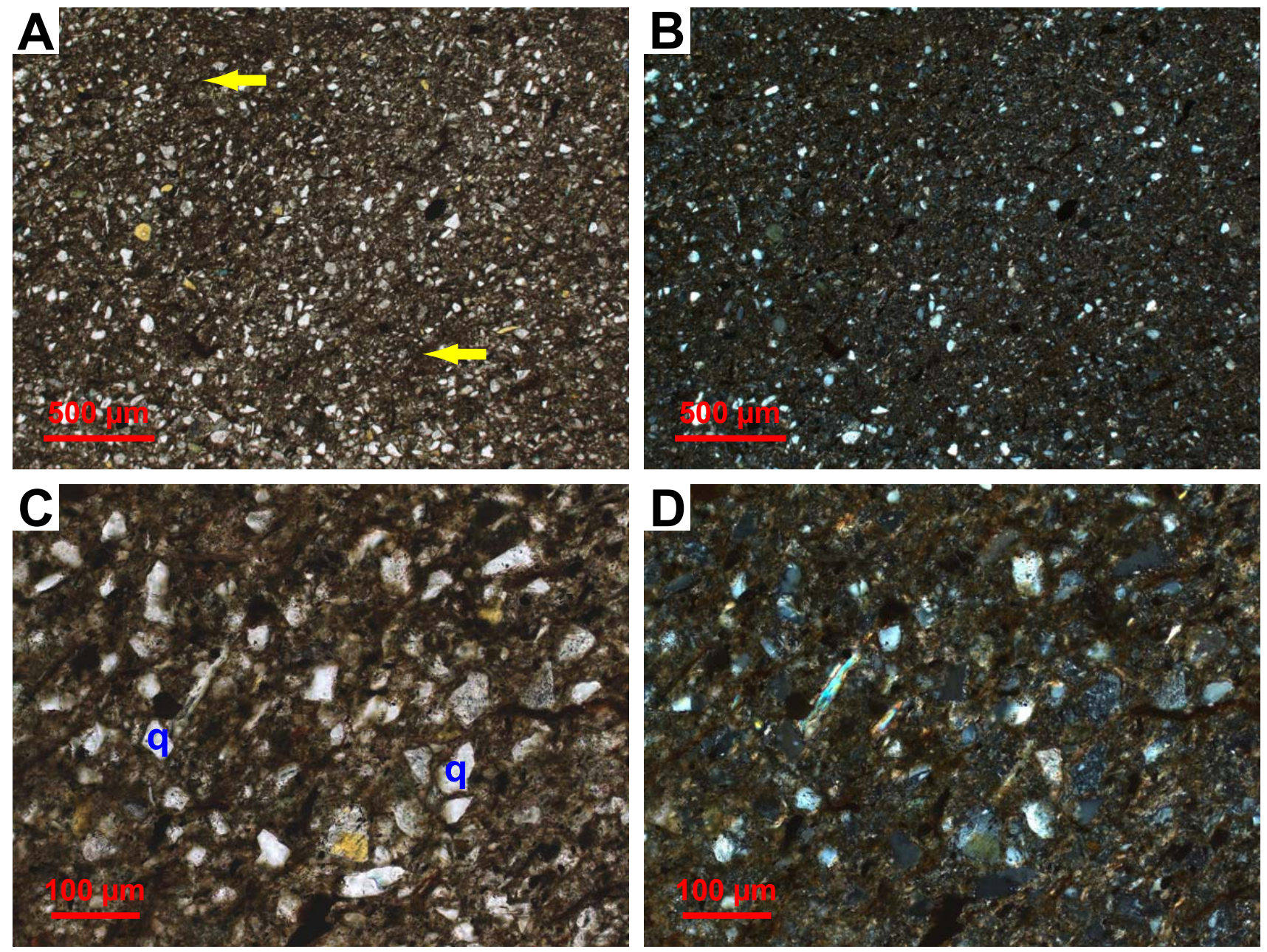

Figure 3-6. Photomicrographs of siltstone petrofacies; sample from 1,160.3 ft. A. General view of siltstone, showing an abundance of detrital clay (yellow arrows). Plane-polarized light. B. Same view as A, but with crossed polars. C. Detailed view of siltstone in which the framework fraction consists largely of monocrystalline quartz (q). Plane-polarized light. D. Same view as $C$, but with crossed polars. 
averages 9 percent of the detrital framework and consists of both grains with 2-5 crystals (plutonic and high-rank metamorphic provenance) and greater than 5 crystals (low-rank metamorphic provenance; Basu and others, 1975; Blatt and others, 1980; Blatt, 1982; Boggs, 2009). Feldspar comprises roughly 9 percent of the framework, consisting of slightly more plagioclase than K-feldspar. Plagioclase shows varying degrees of alteration and dissolution, while K-feldspar is largely unaltered. Lithic fragments (excluding chert) comprise approximately 30 percent of the rock framework, consisting of mudstonesiltstone, felsic volcanic and plutonic grains, quartzite, phyllite, and detrital carbonate. Micas, heavy minerals, and dispersed organic grains occur in trace amounts.

Overall reservoir quality of these sandstones is very good to excellent with an average air permeability of 210 md (193 md Klinkenberg permeability) and average porosity of 25 percent (fig. 3-11). They are largely uncemented and contain only limited detrital matrix. Minor cements include patchy, pore-filling kaolinite and siderite, and occasional ankerite. Siderite locally replaces oversized clay grains (probable clay rip-up clasts) and occurs along mica cleavage, causing the mica to be splayed out. A few overgrowths were observed on monocrystalline quartz grains. The average intergranular volume (IGV) is 23 percent, suggesting that most porosity loss was through compaction.

Fourteen samples of this petrofacies belong to the plane-parallel laminated sandstone (slf and Slm) facies, four to the cross-bedded sandstone (Sx) facies, and three to the massive sandstone (Sm) facies (table 2).

\section{MEDIUM-GRAINED SANDSTONE PETROFACIES}

The medium-grained sandstone petrofacies is represented by three samples that are chert-rich litharenites (fig. 3-9). They have an average modal composition of $\mathrm{Q}_{\mathrm{t70}} \mathrm{F}_{8} \mathrm{~L}_{22}, \mathrm{Q}_{\mathrm{m} 19} \mathrm{~F}_{8} \mathrm{~L}_{\mathrm{t} 73}, \mathrm{Q}_{\mathrm{m} 69} \mathrm{P}_{23} \mathrm{~K}_{8}, \mathrm{Q}_{\mathrm{p} 73} \mathrm{~L}_{\mathrm{vm} 8} \mathrm{~L}_{\mathrm{sm} 19}$ (fig. 3-4, appendix $3-\mathrm{F})$ and a plagioclase/total feldspar $(\mathrm{P} / \mathrm{F})$ ratio of 0.76 . Their average grain size (fig. 3-5, appendix 3-G) is $0.27 \mathrm{~mm}$ (lower medium), with an average Folk sorting (Folk, 1974)
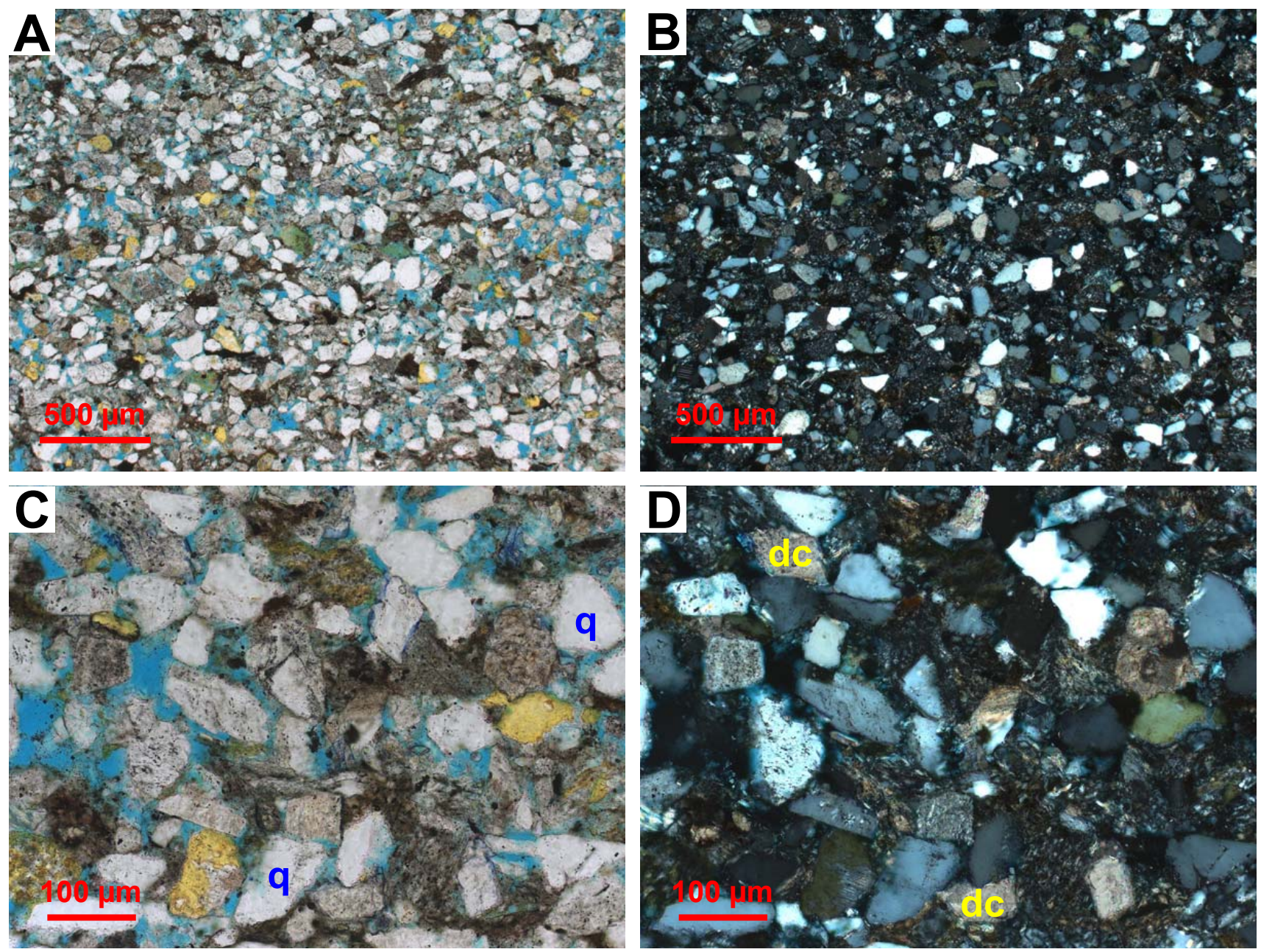

Figure 3-7. Photomicrographs of very-fine-grained sandstone petrofacies; sample from 1,072.1 ft. A. General view, showing a moderately compacted framework lacking significant cements. Plane-polarized light. B. Same view as A, but with crossed polars. C. Detailed view of sandstone, showing abundance of monocrystalline quartz (q). Plane-polarized light. D. Same view as $\mathrm{C}$, but with crossed polars. Note detrital carbonate grains (dc). 
of 0.97 (moderate). Chert and monocrystalline quartz $\left(\mathrm{Q}_{\mathrm{m}}\right)$ are the two dominant framework components, averaging 44 and 17 percent of the framework fraction, respectively. Although chert consists largely of the common, clay-poor, microcrystalline variety, grains of micaceous-argillaceous chert are not uncommon and a few grains of the calcareous-dolomitic and microporous variants were noted. Monocrystalline quartz typically has straight to slightly undulose extinction (fig. 3-9). Polycrystalline quartz $\left(Q_{p}\right)$ averages almost 5 percent of the detrital framework and consists largely of grains with 2-5 crystal units. Feldspar comprises roughly 8 percent of the framework, consisting of three times more plagioclase than K-feldspar. Plagioclase shows varying degrees of alteration and dissolution, while K-feldspar is largely unaltered. Lithic fragments (excluding chert) comprise one-fifth of the rock framework and consist of a variety of lithologies including mudstonesiltstone, felsic volcanic and plutonic grains, quartzite, phyllite, and detrital carbonate. Micas (muscovite, biotite, and chlorite) and heavy minerals occur in trace amounts. Minor organic material occurs as dispersed grains ("coffee grounds") and discontinuous laminae.

Overall reservoir quality of these sandstones is excellent with an average air permeability of $735 \mathrm{md}(695 \mathrm{md}$ Klinkenberg permeability) and average porosity of 26 percent (fig. 3-11). They are largely uncemented and contain little detrital matrix. Minor cements include patchy, porefilling kaolinite and siderite. The average intergranular volume (IGV) is 26 percent, suggesting that most porosity loss was through compaction.

All three samples of this petrofacies belong to the plane-parallel laminated sandstone (Slm) facies (table 3-1).

\section{CARBONATE-CEMENTED SANDSTONE PETROFACIES}

The carbonate-cemented sandstone petrofacies is represented by the two shallowest samples (181.9 and $339.0 \mathrm{ft}$ ), which are extensively cemented by ankerite.
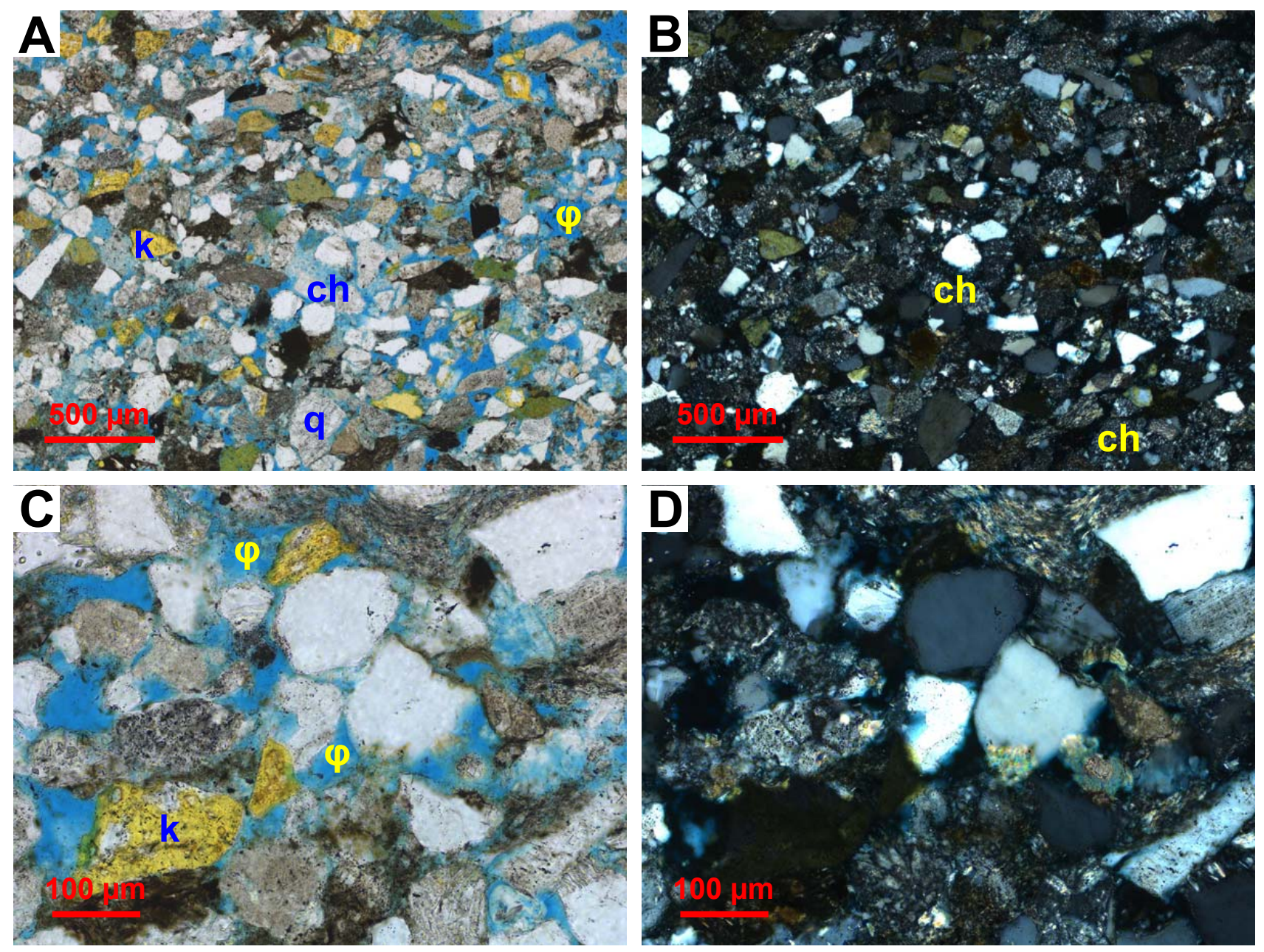

Figure 3-8. Photomicrographs of fine-grained sandstone petrofacies; sample from $654.15 \mathrm{ft}$. A. General view, showing abundance of intergranular pores $(\phi)$, quartz (q), K-feldspar (k), and chert (ch), which is best seen under crossed polars. Plane-polarized light. B. Same view as A, but with crossed polars, showing abundant chert grains (ch). C. Detailed view, showing common intergranular pores $(\phi)$. Note detrital K-feldspar (k). Plane-polarized light. D. Same view as C, but with crossed polars. 
The abundant cement is the key petrographic characteristic that groups these samples into the same petrofacies (fig. 3-10). The two samples have an average grain size (fig. 3-4, appendix 3-G) of $0.07 \mathrm{~mm}$ (lower very fine) and an average Folk sorting (Folk, 1974) of 1.72 (poor). Their detrital composition is similar to other very-fine-grained sandstones from the well, with an average modal composition of $\mathrm{Q}_{t 60} \mathrm{~F}_{15} \mathrm{~L}_{25}, \mathrm{Q}_{\mathrm{m} 35} \mathrm{~F}_{15} \mathrm{~L}_{\mathrm{t} 50}, \mathrm{Q}_{\mathrm{m} 70} \mathrm{P}_{15} \mathrm{~K}_{15}, \mathrm{Q}_{\mathrm{p} 51} \mathrm{~L}_{\mathrm{vm} 4} \mathrm{~L}_{\mathrm{sm} 45}$ (fig. 3-4, appendix 3-F) and a plagioclase/total feldspar (P/F) ratio of 0.50 . Monocrystalline quartz $\left(\mathrm{Q}_{\mathrm{m}}\right)$ is the dominant framework component in both samples, averaging 31 percent of the framework. Other significant detrital components include chert (13 percent), polycrystalline quartz (10 percent), plagioclase (7 percent), and K-feldspar (7 percent). Lithic grains consist largely of sedimentary (detrital carbonate, mudstone, argillite) and metamorphic (phyllite, quartzite) rock fragments. Organic material and micas are minor components.
Overall reservoir quality of these sandstones is very poor to negligible with an average air permeability of $0.002 \mathrm{md}$ ( $0.0005 \mathrm{md}$ Klinkenberg permeability) and average porosity of 2.7 percent (fig. 3-11). They are highly cemented by ankerite (provisional identification is based on distinctive turquoise color resulting from potassium ferricyanide stain), which is virtually the only cement in the sandstones, averaging 43 percent of the bulk rock. The similarity in detrital mineralogy between these highly cemented and the other relatively uncemented veryfine-grained sandstones suggests that cementation was either (1) passively pore-filling with little replacement of detrital grains, or (2) unselective in grain replacement. While some grains do show evidence of etching or partial replacement (fig. 3-10C), the bulk of cementation is interpreted to have been passive. Matrix content varies between the two samples and may be related to grain size. The lower very-fine-grained $(0.078 \mathrm{~mm})$ sandstone at
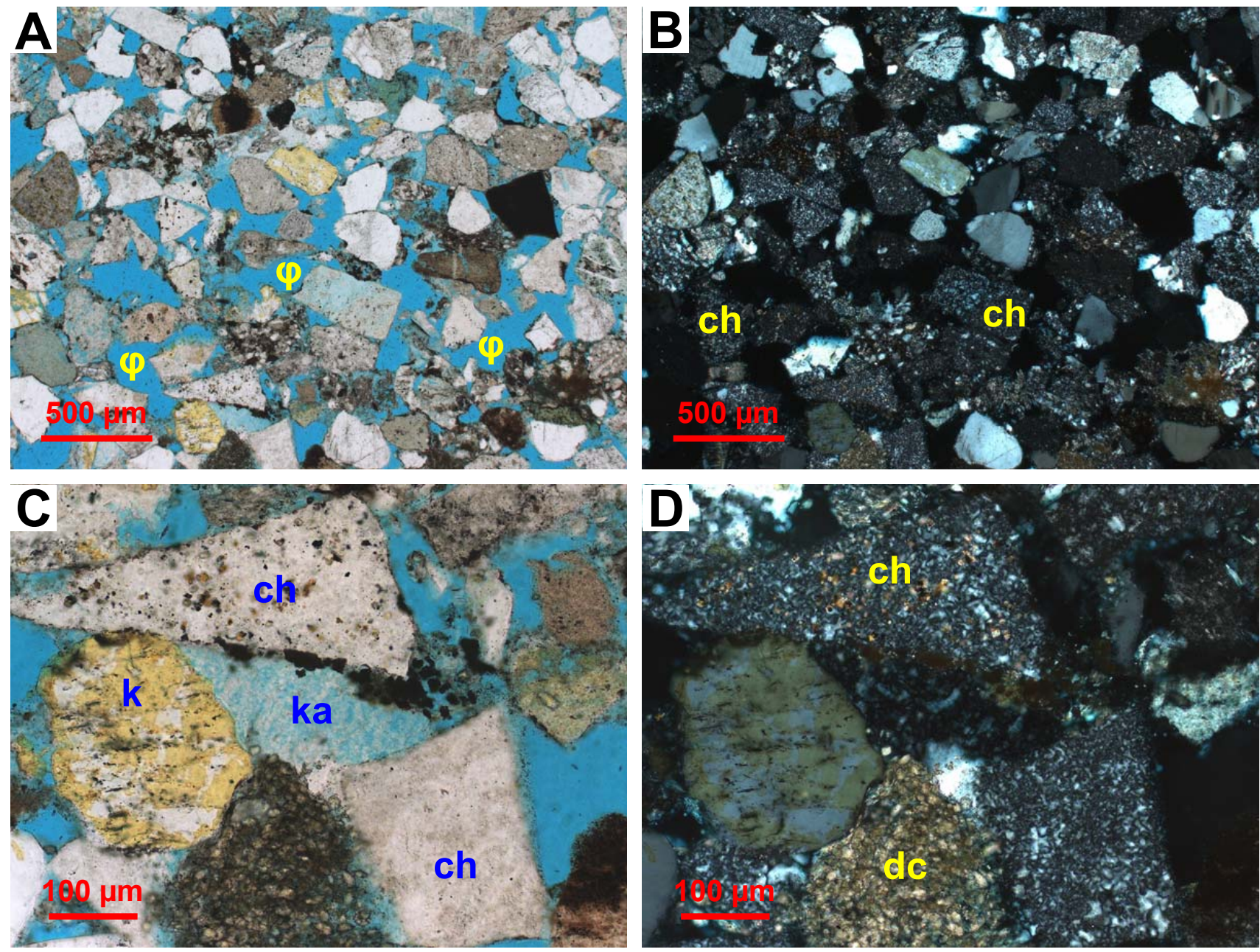

Figure 3-9. Photomicrographs of medium-grained sandstone petrofacies; sample from 1,128.1 ft. A. General view, showing extensive intergranular porosity $(\phi)$. Plane-polarized light. B. Same view as A, except with crossed polars, showing chert (ch) is the dominant framework component. C. Detailed view, showing authigenic kaolinite (ka) filling pore between grains of chert (ch) and K-feldspar (k). Plane-polarized light. D. Same view as C, except with crossed polars; note chert (ch) and detrital carbonate (dc). 
$181.9 \mathrm{ft}$ contains 9.5 percent matrix while the upper veryfine-grained $(0.106 \mathrm{~mm})$ sample at $339 \mathrm{ft}$ contains only 2 percent matrix. The average intergranular volume (IGV) of 49 percent is close to, or greater than, the presumed initial depositional porosity, suggesting that cementation was very early (syndepositional to very shallow burial) and that virtually no porosity was lost through compaction.

One sample of this petrofacies belongs to the massive sandstone $(\mathrm{Sm})$ facies, the other to the ripple cross-laminated sandstone (Sr) facies (table 3-1).

\section{GRAIN-SIZE TRENDS}

The Wainwright siltstones and sandstones exhibit well-developed relationships among texture, composition, and reservoir quality. In particular, grain size has a high degree of correlation with several parameters including porosity, permeability, and grain composition, as illustrated by chert, monocrystalline quartz, and VRFs.
It should be noted that because grain size is given in phi $(\varphi)$, which is defined as $-\log _{2}$ (grain size ${ }_{\mathrm{mm}}$ ), a positive correlation between variables (for example, permeability increases with increasing grain size) is actually reported as a negative value of the Pearson product-moment correlation coefficient ( $r$ ) (table 3-2). Likewise, to best display a linear relationship among variables, the ordinate (y-axis) on several of the cross-plots is commonly displayed with a logarithmic scale.

A good correlation exists between grain size and reservoir quality as expressed by porosity and permeability. There is a pronounced linear relationship between grain size and porosity, with a Pearson product-moment correlation coefficient ( $r$ ) of - 0.94 (table 3-2). The medium- and fine-grained sandstones have average porosity of 26 and 25 percent, respectively, while the siltstone porosity averages 15 percent (fig. 3-12A). To ascertain whether this trend is exhibited by Nanushuk Formation sandstones from other localities, data from 25 additional North Slope wells (table
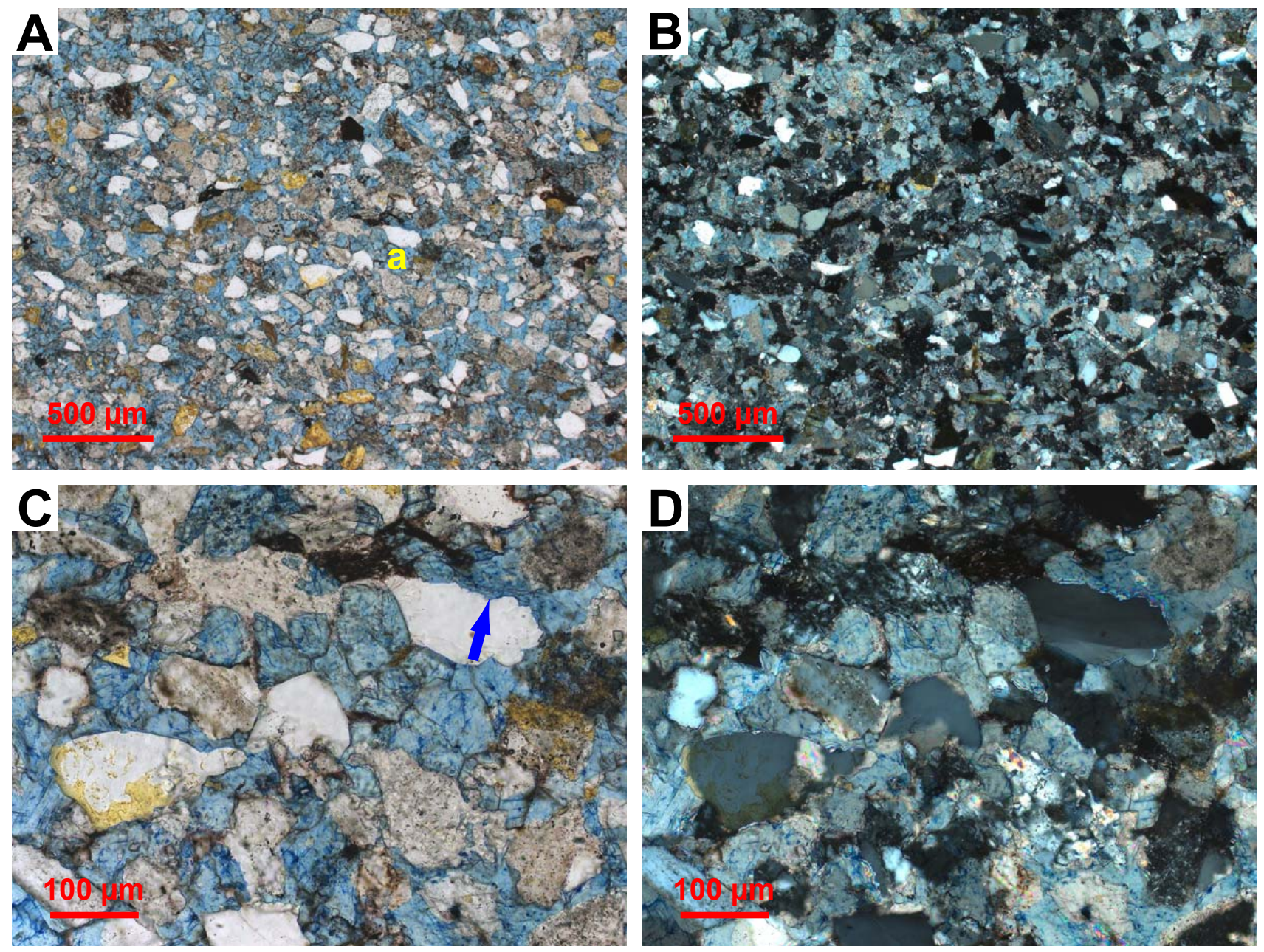

Figure 3-10. Photomicrographs of carbonate-cemented sandstone petrofacies; sample from 335.0 ft. A. General view showing extensive ankerite (a) cement. An intergranular volume (IGV) approaching 45 percent suggests that cementation occurred shortly after deposition and prior to significant burial. Plane-polarized light. B. Same view as A, except with crossed polars. C. Detailed view, showing irregular edges of grains (blue arrow), suggesting some grain replacement might have occurred. Plane-polarized light. D. Same view as C, except with crossed polars. 
3-3) were included in the plots for comparison. Based on this limited dataset, it appears this trend is not evident in the regional Nanushuk data, where sandstones of equivalent grain size have substantially lower porosity with a greater standard deviation. There is also a pronounced linear relationship between grain size and permeability, with an average permeability of $735 \mathrm{md}$ in the mediumgrained sandstones and only $1 \mathrm{md}$ in the siltstones (fig. 3-12B). It is universally recognized that with all other factors being equal, coarser sediments have larger pore throats, resulting in enhanced fluid mobility (Beard and Weyl, 1973). For the regional Nanushuk samples, permeability for a given grain size is substantially lower and exhibits greater variability than permeability exhibited by the Wainwright samples. The reason for the disparity in the reservoir quality versus grain size relationships between the Wainwright and regional Nanushuk sandstones is interpreted to reflect differences in burial and is discussed in the following section.

The relationship between grain size and framework composition is well illustrated by detrital chert (correlation coefficient of -0.93), with the medium-grained sandstones averaging more than 30 percent (whole rock) chert, while the siltstones average slightly over 2 percent (fig. 3-12C). The regional Nanushuk sandstones show a similar correlation, suggesting the grain size versus
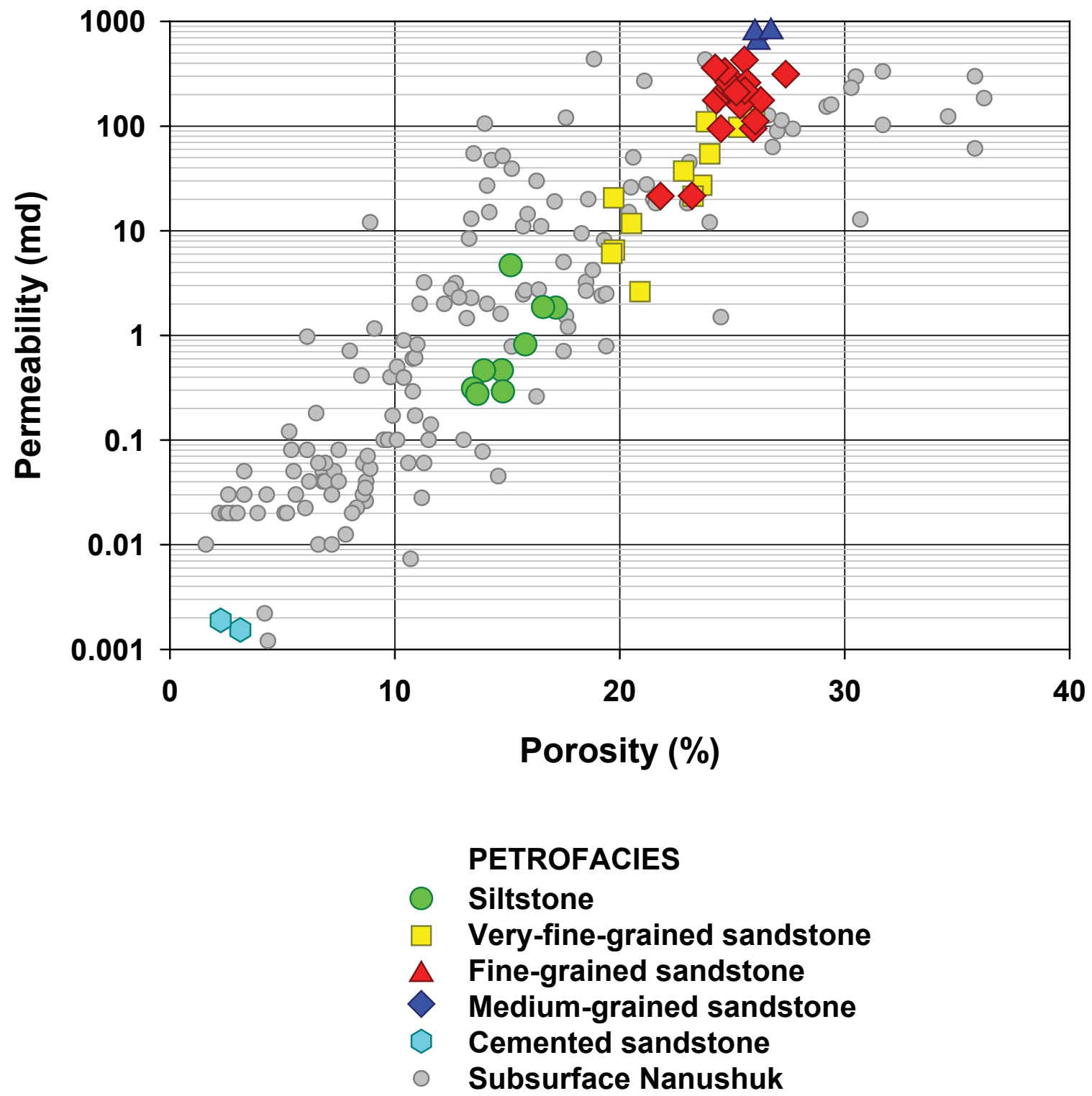

Figure 3-11. Porosity-permeability cross plot showing reservoir quality of Wainwright and regional Nanushuk sandstones included in this report. Of the non-cemented Wainwright samples, the medium- and fine-grained sandstones have the best reservoir quality (very good to excellent), while the siltstones have the poorest (moderately poor to poor). The carbonate-cemented rocks have negligible reservoir quality. 

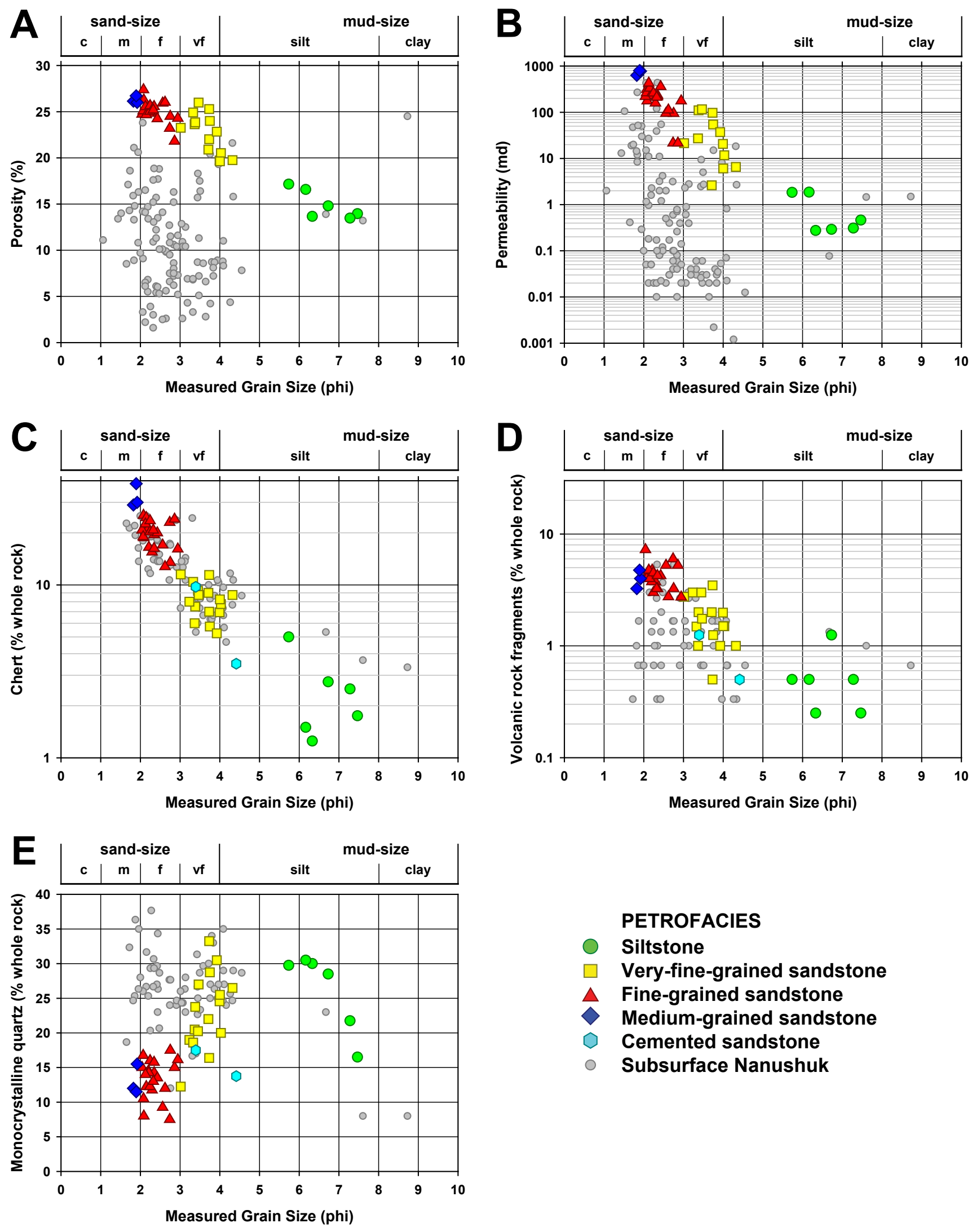
Figure 3-12 (left). Cross plots of grain size in phi $(\phi)$ versus several petrophysical and compositional parameters. Because grain size is given in phi $(\phi)$, which is defined as $-\log _{2}$ (grain size ${ }_{\mathrm{mm}}$ ), a positive correlation between variables (permeability increases with increasing grain size) is actually reported as a negative value of the Pearson product-moment correlation coefficient ( $r$ ). Likewise, to best display a linear relationship between variables, the ordinate (y-axis) is commonly displayed with a logarithmic scale. A. Porosity-grain-size plot, showing the well-developed relationship between the two variables ( $r$ $=-0.93$ ) for the Wainwright samples. The regional Nanushuk sandstones do not show as good a correlation largely because they have been subjected to deeper burial. B. Permeability-grain-size plot shows a similar very good correlation between the two variables for the Wainwright samples that is not shared by the regional Nanushuk sandstones. C. Chert-grainsize plot showing very good correlation for both the Wainwright and regional samples. Chert preferentially resides in the coarser fraction of the detritus. D. Volcanic rock fragments (VRF)-grain-size plot showing good correlation for Wainwright and regional samples. E. Monocrystalline quartz $\left(Q_{m}\right)$-grain-size plot, showing good correlation for the Wainwright and regional sandstones. Wainwright siltstones have lower quartz content due to dilution by abundant detrital clay.

chert relationship may be universal among Nanushuk sandstones. A possible explanation for this trend may lie in the origin of the chert grains.

Potential sources include the Mississippian-Pennsylvanian Lisburne Group, mid-Pennsylvanian-Permian Imnaitchiak chert, and Triassic Otuk Formation (Mull, 1995). Large (cobble- to boulder-sized) chert nodules are widespread in the Lisburne carbonates and Imnaitchiak chert, while thin-bedded (2-6-inch-thick beds) chert predominates in the Otuk Formation (Mull, 1995). In either case, as nodular and/or bedded chert clasts weather and erode from the host lithologies, their size would dictate concentration in the coarsest detritus. With continued transport and abrasion, chert grains of silt to very-fine sand size should ultimately be produced if its solubility were comparable to that of quartz; but that is not the case in these Nanushuk sandstones. Perhaps in these finer fractions the higher solubility of chert relative to monocrystalline quartz (Aase and others, 1996; Jahren and Ramm, 2000), combined with greater surface area, may result in its selective dissolution, thereby increasing the relative abundance of quartz. Bedded chert typically contains clay and other impurities compared to modular chert, which is usually isotropic (Mull, 1995), possibly making the former more susceptible to dissolution (Wartes, oral commun.). A similar grain-size relationship is also seen in Ivishak sandstones from the North Slope of Alaska, where chert content is thought to be related to distance of transport (Atkinson and others, 1990).

A similar, although less pronounced, relationship exists between grain size and volcanic rock fragment (VRF) content where the medium- and fine-grained sandstones average 4 percent (whole rock) VRFs while the siltstones average 0.5 percent (fig. 3-12D). The regional Nanushuk data for VRFs show similar abundance (0.2-5 percent), although the correlation is not as convincing. In the cases of both chert and VRFs, the lithic grains are concentrated in the coarser detritus.

A complementary relationship exists for grain size and monocrystalline quartz, where the medium-grained sandstones average 13 percent (whole rock) $Q_{m}$ while the siltstones average 26 percent (fig. 3-12E). The correlation coefficient of 0.67 for the entire dataset increases to 0.80 for just the sand fraction (siltstones excluded). The regional Nanushuk data for $Q_{m}$ are similar (8-38 percent spread), although the correlation is less pronounced.

\section{RESERVOIR QUALITY}

Reservoir quality (porosity and permeability) of the Wainwright sandstones varies widely from very poor (cemented sandstones) to excellent (medium-grained sandstone) and, with the exception of the cemented samples, is largely controlled by grain size, which is a proxy for depositional environment. The porosity-permeability trend for the Wainwright samples parallels that of the regional Nanushuk trend, although a larger proportion of the regional sandstones have poor to very poor reservoir quality (fig. 3-11). This disparity in reservoir quality results from differences in burial, specifically the maximum burial the rocks experienced. The Wainwright test well is located along the northern Alaska coastline, where the amount of removed overburden is estimated at $2,762 \mathrm{ft}$ (fig. 3-13, modified from Burns and others, 2005). That amount, added to the current burial depths of Wainwright samples, yields maximum depths of burial $\left(D_{\max }\right)$ ranging from 2,944 to $4,263 \mathrm{ft}$, generally considered shallow to moderate burial. In contrast, many of the wells in the regional dataset are up to $100 \mathrm{mi}$ south of the Barrow arch, where estimates of removed overburden approach 9,000 $\mathrm{ft}$ (fig. 3-13, table 3-3). As a result, the maximum depth of burial for many of these samples approaches $10,000 \mathrm{ft}$ (fig. 3-14), which is traditionally considered deep burial.

Differences in reservoir quality are graphically illustrated in a PFC (porosity-framework-cement) diagram (fig. 3-15), a technique originally proposed by Franks and Lee (1994). The Wainwright sandstones largely plot in the field of "compacted reservoir" while the siltstones fall into the "compacted non-reservoir" area of the diagram. The regional Nanushuk sandstones are largely confined to the "compacted reservoir" and "compacted non-reservoir" fields, although a few samples plot in the "preserved reservoir" portion of the diagram. A limited number of the Wainwright and regional samples lie in the "cemented non-reservoir" field, attesting that porosity is largely destroyed by compaction. This is confirmed by a cross plot of compactional porosity loss (COPL; Lundegard, 1992) versus cementational porosity loss (CEPL), which 


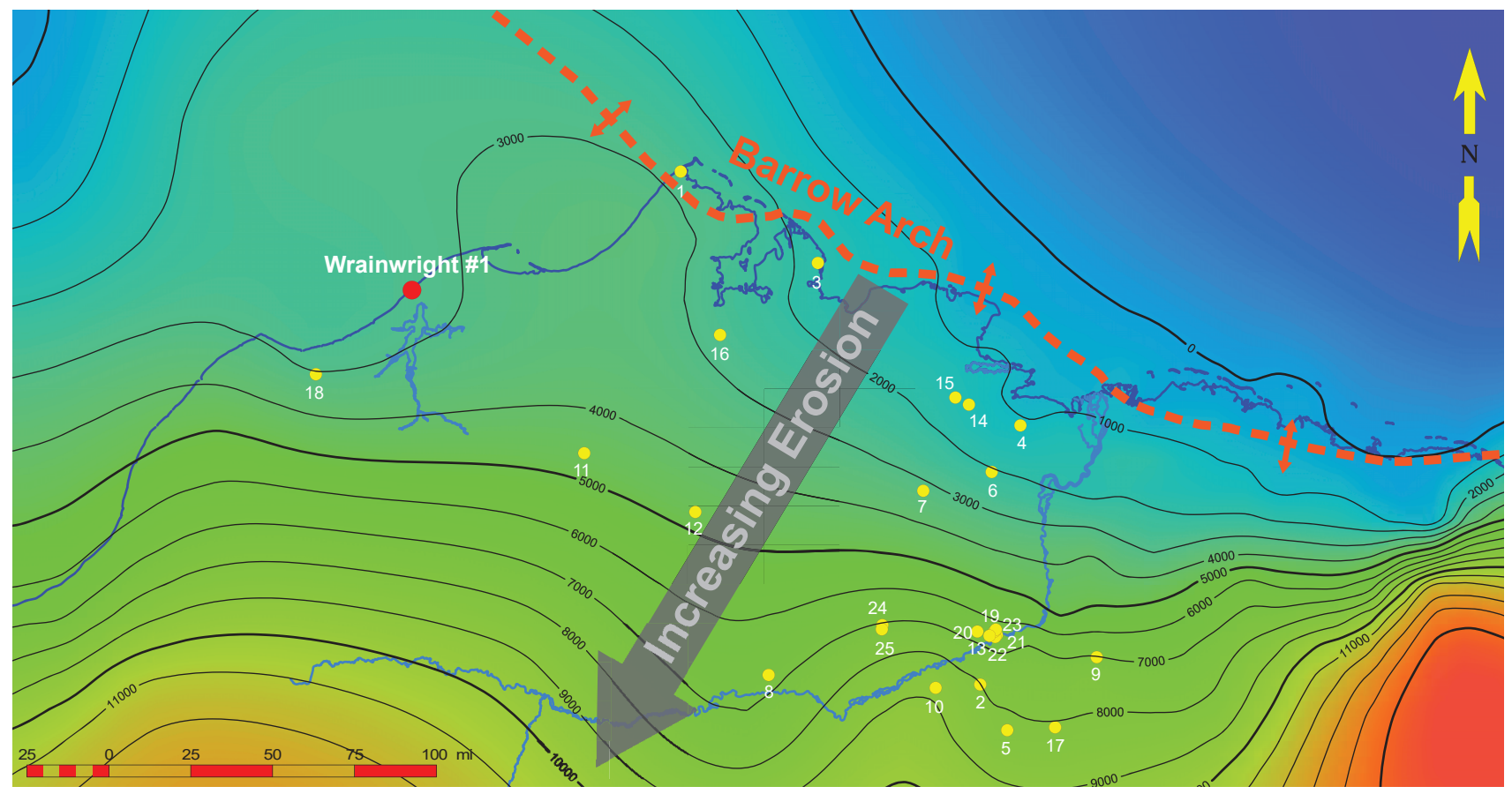

Figure 3-13. Contoured map of the central North Slope of Alaska, showing estimates of the amount (in feet) of Brookian strata removed by erosion. Red dot shows the location of the Wainwright \#1 test well; yellow dots show locations of 25 wells for which data are included in scatter and ternary plots (table 3-3). The large arrow shows the regional trend of increasing amounts of erosion to the south. Contours were generated from the data of Burns and others (2005) using the GeoAtlas mapping module of GeoGraphix (minimum curvature algorithm with smallest feature radius of 50,000 $\mathrm{ft}$ and radius of influence of $1,000,000 \mathrm{ft}$ ).

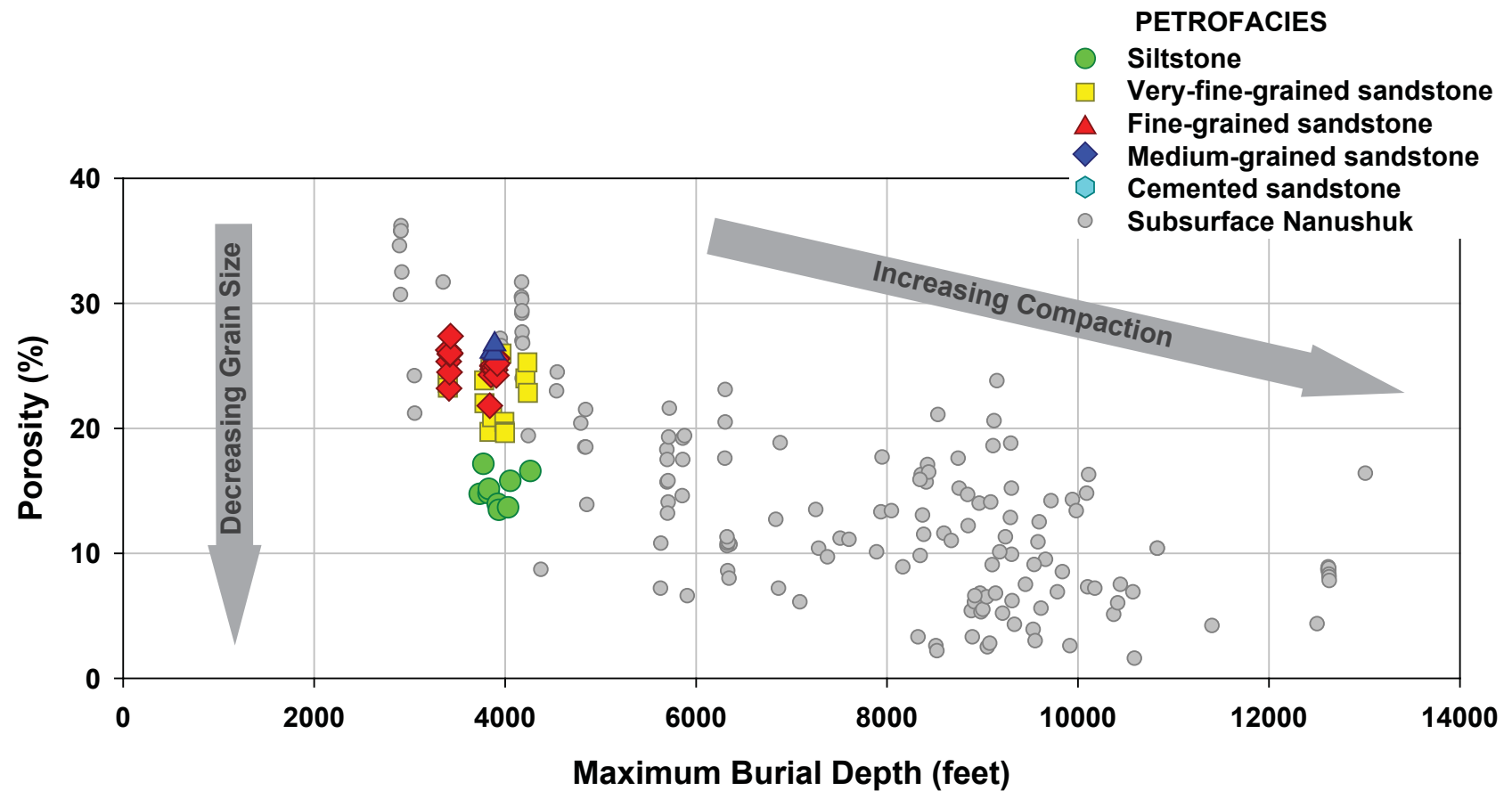

Figure 3-14. Cross plot of porosity versus maximum burial depth $\left(D_{\max }\right)$ for the Wainwright and regional Nanushuk siltstones and sandstones. The Wainwright samples have $D_{\max }$ values ranging from 2,944 to 4,263 ft, while most of the regional Nanushuk samples were buried to greater depths $\left(D_{\max }>6,000 \mathrm{ft}\right)$. The arrows point out the two major controls on Nanushuk reservoir quality: Grain size and compaction. At any given value of $D_{\text {max }}$, reservoir quality is largely controlled by grain size, which is a proxy for environment of deposition. At the regional scale, compaction has a significant effect on reservoir quality. 
shows a similar relationship (fig. 3-16). The vast majority of Wainwright and regional Nanushuk sandstones have COPL values of 25-45 percent with corresponding CEPL values of less than 8 percent, confirming that cementation does not play a major role in porosity destruction. Reservoir quality is largely controlled by two separate processes: Local grain-size effects and regional compaction (fig. 3-14). On the local scale at any given geographic location, porosity and permeability are mainly a function of grain size, which is determined by the sedimentary environment where the detritus was deposited. From a regional perspective, porosity and permeability are reduced as the sediments, regardless of depositional environment, are buried to greater depths. Hence, there is a decrease in overall reservoir quality from north to south corresponding to greater amounts of burial and removed overburden. In areas that have not seen significant burial, such as the vicinity of the Barrow arch, there is usually a large spread in porosity and permeability controlled almost exclusively by grain size. In areas that have undergone deep burial, such as the vicinity of the Brooks Range deformation front, the variability of porosity and permeability in any given core is reduced, being controlled by both grain size and compaction (fig. 3-14).

\section{ф}

\section{$45 \%$}

$\mathbf{F}$

$100 \%$

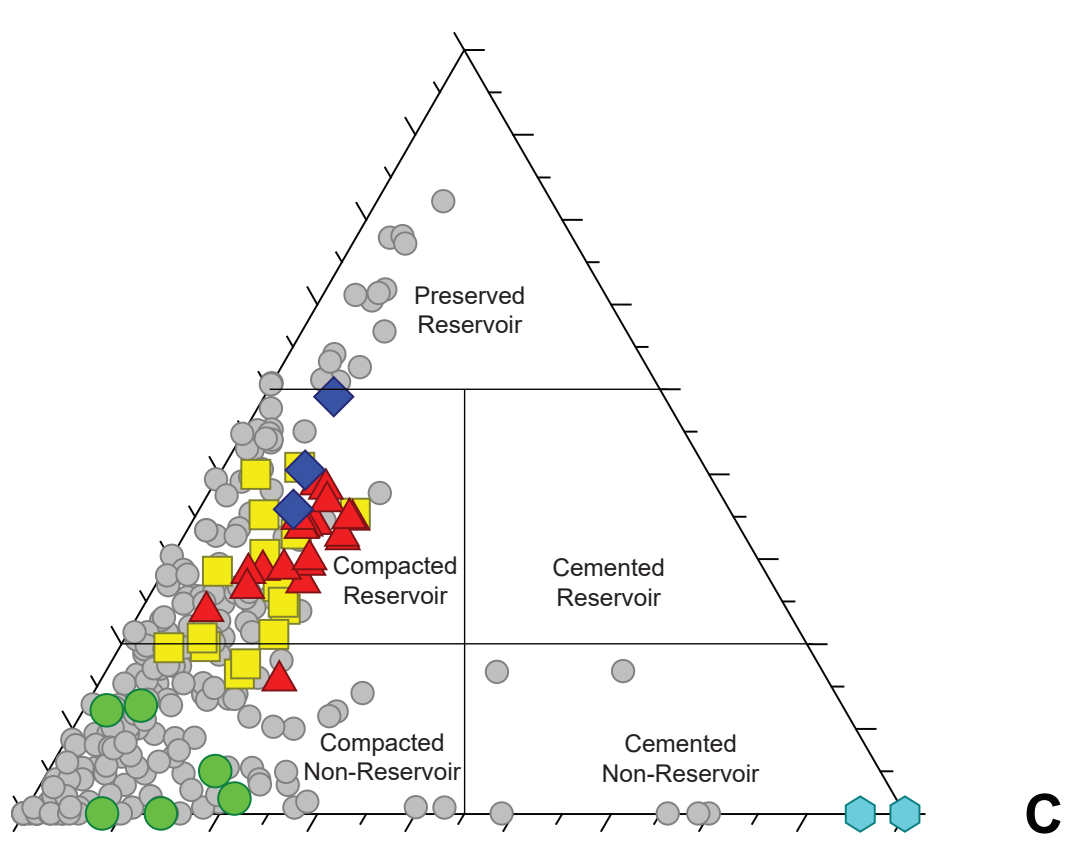

$45 \%$

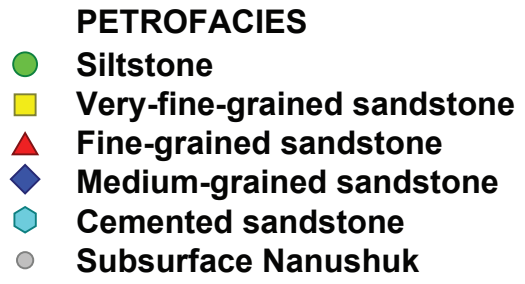

Figure 3-15. Porosity-Framework-Cement $(\phi-F-C)$ ternary diagram showing reservoir quality of the Wainwright and regional Nanushuk siltstones and sandstones. The Wainwright siltstones plot in the "compacted non-reservoir" area of the diagram, while most of the Wainwright sandstones plot in the "compacted reservoir" field. The regional Nanushuk sandstones plot mainly in the "compacted non-reservoir" and "compacted reservoir" fields, although a few are in the "preserved reservoir" and "cemented non-reservoir" fields. This confirms that porosity loss in Nanushuk sandstones is dominantly through compaction. Diagram modified from Franks and Lee (1994); used with permission. 

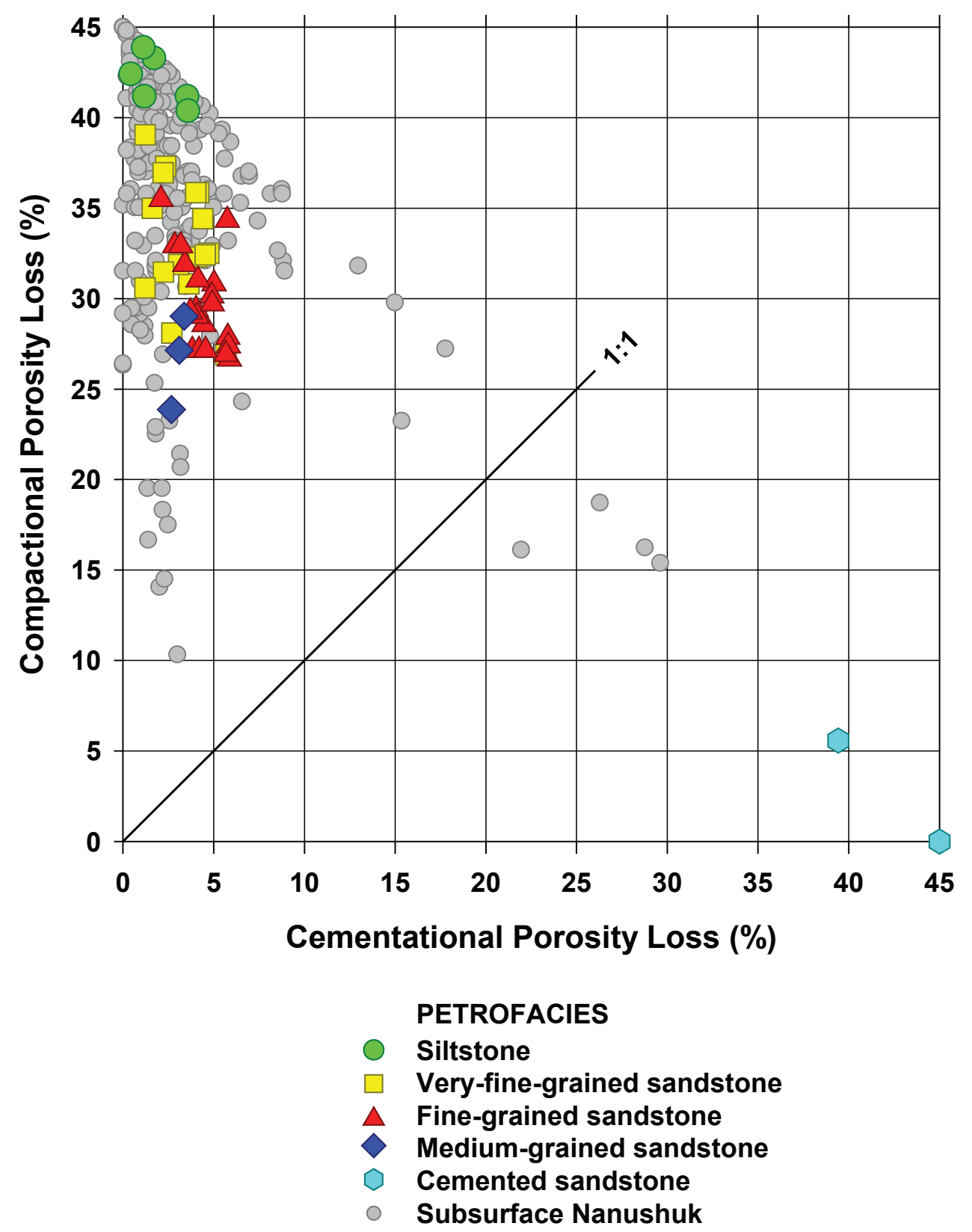

Figure 3-16. Cross plot of compactional porosity loss versus cementational porosity loss for Wainwright and regional Nanushuk siltstones and sandstones. Samples with cementational porosity loss greater than 45 percent (Wainwright \#1, $181.9 \mathrm{ft}$ ) are arbitrarily set to the assumed maximum intergranular volume of 45 percent. The diagonal line (1:1) represents equal porosity loss by compaction and cementation. Most of the porosity loss in all samples was through compaction. Diagram modified from Lundegard (1992). 


\section{ACKNOWLEDGMENTS}

Funding for this work was provided by the State of Alaska; additional funding for routine core analyses was provided by the U.S. Geological Survey. David Houseknecht and Ken Bird provided access to the core plug trim-ends from which Mark Mercer of Petrographics, LLC, provided superb, high-quality thin sections. David L. LePain reviewed an early version of the manuscript and provided many helpful suggestions. Insightful formal reviews by Marwan A. Wartes, Paul J. McCarthy, and Nina T. Harun were very helpful in improving the final report.

\section{REFERENCES CITED}

Aase, N.E., Bjorkum, P.A., and Nadeau, P.H., 1996, The effect of grain-coating microquartz on preservation of reservoir porosity: American Association of Petroleum Geologists Bulletin, v. 80, no. 10, p. 1,654-1,673. doi:10.1306/64EDA0F0-1724-11D7-8645000102C1865D

Ahlbrandt, T.S., Huffman, A.C., Fox, J.E., and Pasternack, I., 1979, Depositional framework and reservoir quality studies of selected Nanushuk Group outcrops, North Slope, Alaska, in Ahlbrandt, T.S., ed., Preliminary geologic, petrologic, and paleontologic results of the study of Nanushuk Group rocks, North Slope, Alaska: U.S. Geological Survey Circular 794, p. 14-31. http:// pubs.usgs.gov/circ/1979/0794/report.pdf

Atkinson, C.D., McGowen, J.H., Bloch, Salman, Lundell, L.L., and Trumbly, P.N., 1990, Braidplain and deltaic reservoir, Prudhoe Bay Field, Alaska, in Barwis, J.H., McPherson, J.G., Studlick, J.R.J., and Ginsburg, R.N., eds., Sandstone Petroleum Reservoirs: New York, Springer-Verlag, p. 205-224.

Bartsch-Winkler, Susan, 1979, Textural and mineralogical study of some surface and subsurface sandstones from the Nanushuk Group, western North Slope, Alaska, in Ahlbrandt, T.S., ed., Preliminary geologic, petrologic, and paleontologic results of the study of Nanushuk Group rocks, North Slope, Alaska: U.S. Geological Survey Circular 794, p. 61-76. http://pubs.usgs.gov/ circ/1979/0794/report.pdf

Bartsch-Winkler, Susan, 1985, Petrography of sandstones of the Nanushuk Group from four measured sections, central North Slope, Alaska, in Huffman, A.C., Jr., ed., Geology of the Nanushuk Group and related rocks, North Slope, Alaska: U.S. Geological Survey Bulletin 1614, p. 75-95. http://www.dggs.alaska.gov/pubs/ id/3709

Bartsch-Winkler, Susan, and Huffman, A.C., Jr., 1988, Sandstone petrography of the Nanushuk Group and Torok Formation, in Gryc, George, ed., Geology and exploration of the National Petroleum Reserve in Alaska, 1974 to 1982: U.S. Geological Survey Professional Paper 1399, p. 801-831. http://dggs.alaska.gov/pubs/id/4007

Basu, A., Young, S.W., Suttner, L.J., James, W.C., and Mack, G.H., 1975, Re-evaluation of the use of undulatory extinction and polycrystallinity in detrital quartz for provenance interpretations: Journal of Sedimentary Petrology, v. 45, no. 4, p. 873-882. doi:10.1306/212F6E6F2B24-11D7-8648000102C1865D

Beard, D.C., and Weyl, P.K., 1973, Influence of texture on porosity and permeability of unconsolidated sand: American Association of Petroleum Geologists Bulletin, v. 57, no. 2, p. 349-369. doi:10.1306/819A4272-16C511D7-8645000102C1865D

Blatt, Harvey, 1982, Sedimentary petrology: New York, W.H. Freeman and Company, 514 p.

Blatt, Harvey, Middleton, Gerard, and Murray, Raymond, 1980, Origin of sedimentary rock, 2nd edition: Englewood Cliffs, NJ, Prentice-Hall, Inc., 766 p.

Boggs, Sam, Jr., 2009, Petrology of sedimentary rocks, 2nd edition: New York, Cambridge University Press, 599 p.

Burns, W.M., Hayba, D.O., Rowan, E.L., and Houseknecht, D.W., 2005, Estimating the amount of eroded section in a partially exhumed basin from geophysical well logs-An example from the North Slope: Studies by the U.S. Geological Survey in Alaska, 2005, U.S. Geological Survey Professional Paper 1732-D, 18 p. http://pubs. usgs.gov/pp/pp1732/

Clark, A.C., 2014, Coalbed natural gas exploration, drilling activities, and geologic test results, 2007-2010, Wainwright, Alaska: U.S. Geological Survey Open-File Report 2014-1004, 65 p. doi:10.3133/ofr20141004

Decker, J.E., 1985, Sandstone model analysis procedure: Alaska Division of Geological \& Geophysical Surveys Public Data File 85-3, 38 p. doi:10.14509/1084

Decker, J.E., and Helmold, K.P., 1985, The effect of grain size on detrital modes-A test of the Gazzi-Dickinson point-counting method-Discussion: Journal of Sedimentary Petrology, v. 55, no. 4, p. 618-620.

Decker, P.L., 2010, Brookian sequence stratigraphic framework of the northern Colville foreland basin, central North Slope, Alaska [poster and presentation]: Alaska Department of Natural Resources Spring Technical Review Meeting, Anchorage, April 21-22, 2010: Alaska Division of Geological \& Geophysical Surveys, 30 p., 1 sheet. doi:10.14509/21861

Decker, P.L., and LePain, D.L., 2016 [this volume], Subsurface relationships of Albian-Cenomanian shallow marine to nonmarine topsets of the Nanushuk Formation, northwestern NPRA, northern Alaska, in LePain, D.L., ed., Stratigraphic and reservoir quality studies of continuous core from the Wainwright \#1 coalbed methane test well, Wainwright, Alaska: Alaska Division of Geological \& Geophysical Surveys Report of Investigation 2016-3, 56 p. doi:10.14509/29655

Folk, R.L., 1974, Petrology of sedimentary rocks: Austin, TX, Hemphill Publishing Co., 182 p.

Franks, S.G., and Lee, M.K., 1994, Preliminary report on diagenesis of upper Cook Inlet sandstones: Atlantic Richfield Company report, $46 \mathrm{p}$.

Garrity, C.P., Houseknecht, D.W., Bird, K.J., Potter, C.J., Moore, T.E., Nelson, P.H., and Schenk, C.J., 2005, U.S. 
Geological Survey 2005 oil and gas resource assessment of the central North Slope, Alaska-Play maps and results: U.S. Geological Survey Open-File Report 2005-1182, 25 p. http://pubs.usgs.gov/of/2005/1182/

Gillis, R.J., Decker, P.L., Wartes, M.A., Loveland, A.M., and Hubbard, T.D., 2014, Geologic map of the south-central Sagavanirktok Quadrangle, North Slope, Alaska: Alaska Division of Geological \& Geophysical Surveys Report of Investigation 2014-4, 24 p., 2 sheets, scale 1:63,360. doi:10.14509/29138

Houseknecht, D.W., and Schenk, C.J., 2001, Depositional sequences and facies in the Torok Formation, National Petroleum Reserve-Alaska (NPRA), in Houseknecht, D.W., ed., NPRA core workshop-Petroleum plays and systems in the National Petroleum Reserve-Alaska: Society for Sedimentary Geology (SEPM) Core Workshop Notes, v. 21, p. 179-199. doi:10.2110/cor.01.01.0179

Houseknecht, D.W., Bird, K.J., and Schenk, C.J., 2008, Seismic analysis of clinoform depositional sequences and shelf-margin trajectories in Lower Cretaceous (Albian) strata, Alaska North Slope: Basin Research, v. 21, no. 5, p. 644-654. doi:10.1111/j.1365-2117.2008.00392.x

Howard, J.J., 1992, Influence of authigenic clay minerals on permeability, in Houseknecht, D.W., and Pittman E.D., eds., Origin, diagenesis, and petrophysics of clay minerals in sandstones: Society of Economic Geologists and Paleontologists Special Publication No. 47, p. 257-264. Huffman, A.C., Ahlbrandt, T.S., Pasternack, Ira, Stricker, G.D., and Fox, J.E., 1985, Depositional and sedimentologic factors affecting the reservoir potential of the Cretaceous Nanushuk Group, central North Slope, in Huffman, A.C., ed., Geology of the Nanushuk Group and related rocks, North Slope, Alaska: U.S. Geological Survey Bulletin 1614, p. 61-74. http://dggs.alaska.gov/ pubs/id/4561

Ingersoll, R.V., Bullard, T.F., Ford, R.L., Grimm, J.P., Pickle, J.D. and Sares, S.W., 1984, The effect of grain size on detrital modes-A test of the Gazzi-Dickinson pointcounting method: Journal of Sedimentary Petrology, v. 54, no. 1, p. 103-116. doi:10.1306/212F83B9-2B2411D7-8648000102C1865D

Jahren, J., and Ramm, M., 2000, The porosity-preserving effects of microcrystalline quartz coatings in arenitic sandstones-Examples from the Norwegian continental shelf, in Worden, R.H. and Morad, S., eds., Quartz cementation in sandstones: International Association of Sedimentologists Special Publication, v. 29, p. 271-280. doi:10.1002/9781444304237.ch18

Johnsson, M.J., and Sokol, N.K., 2000, Stratigraphic variation in petrographic composition of Nanushuk Group sandstones at Slope Mountain, North Slope, Alaska, in Kelley, K.D., and Gough, L.P., eds., Geologic studies in Alaska by the U. S. Geological Survey, 1998: U.S. Geological Survey Professional Paper 1615, p. 83-100. http://pubs.usgs.gov/pp/p1615/
LePain, D.L., and Decker, P.L., 2016 [this volume], Lithofacies analysis of the Wainwright \#1 continuous core, western Arctic Slope, Alaska-Transition from lower to upper delta plain environments in the Albian-Cenomanian Nanushuk Formation, in LePain, D.L., ed., Stratigraphic and reservoir quality studies of continuous core from the Wainwright \#1 coalbed methane test well, Wainwright, Alaska: Alaska Division of Geological \& Geophysical Surveys Report of Investigation 2016-3, 56 p. doi:10.14509/29656

LePain, D.L., McCarthy, P.J., and Kirkham, R., 2009, Sedimentology and stratigraphy of the Middle AlbianCenomanian Nanushuk Formation in outcrop, central North Slope, Alaska: Alaska Division of Geological \& Geophysical Surveys Report of Investigation 2009-1, version 2, 76 p. doi:10.14509/19761

Lundegard, P.D., 1992, Sandstone porosity loss-A "big picture" view of the importance of compaction: Journal of Sedimentary Petrology, v. 62, no. 2, p. 250-260.

Molenaar, C.M., 1985, Subsurface correlations and depositional history of the Nanushuk Group and related strata, North Slope, Alaska, in Huffman, A.C., ed., Geology of the Nanushuk Group and related rocks, North Slope, Alaska: U.S. Geological Survey Bulletin 1614, p. 61-74. http://pubs.usgs.gov/pp/1614/pp1614_report.pdf

Mull, C.G., 1995, The geological distribution of chert in the Brooks Range: Alaska Division of Geological \& Geophysical Surveys Public Data File 95-32, 13 p. doi:10.14509/1711

Mull, C.G., Houseknecht, D.W., and Bird, K.J., 2003, Revised Cretaceous and Tertiary stratigraphic nomenclature in the Colville Basin, northern Alaska: U.S. Geological Survey Professional Paper 1673, 59 p. http://dggs. alaska.gov/pubs/id/4052

Neasham, J.W., 1977, The morphology of dispersed clay in sandstone reservoirs and its effect on sandstone shaliness, pore space, and fluid flow properties [presentation SPE 6858]: Society of Petroleum Engineers Annual Technical Conference and Exhibition, Denver, CO, October 9-12, 1977.

Reifenstuhl, R.R., and Loveland, Andrea, 2004, Reservoir characterization study: porosity and permeability of 148 Tertiary to Mississippian age outcrop samples, east-central Brooks Range Foothills and North Slope, Alaska: Alaska Division of Geological \& Geophysical Surveys Preliminary Interpretive Report 2004-5, 21 p. doi: $10.14509 / 3312$

Velleman, P.F., 1998, Learning data analysis with the student version of Data Desk 6.0: Ithaca, New York, Addison-Wesley, $362 \mathrm{p}$. 